\title{
AVALIAÇÃO DA REPRODUTIBILIDADE INTEREXAMINADORES NA PALPAÇÃO MUSCULAR, APÓS UM PROGRAMA DE CALIBRAÇÃO
}

\section{Carlos Neanes Santos}

Dissertação apresentada a Faculdade de Odontologia de Bauru, da Universidade de São Paulo, como parte dos requisitos para obtenção do título de Mestre em Odontologia - área de Reabilitação Oral.

\section{BAURU}

2000 


\section{AVALIAÇÃO DA REPRODUTIBILIDADE INTEREXAMINADORES NA PALPAÇÃO MUSCULAR, APÓS UM PROGRAMA DE CALIBRAÇÃO}

\section{Carlos Neanes Santos}

Dissertação apresentada a Faculdade de Odontologia de Bauru, da Universidade de São Paulo, como parte dos requisitos para obtenção do título de Mestre em Odontologia - área de Reabilitação Oral.

(Edição Revista)

Orientador:

Prof. Dr. Paulo César Rodrigues Conti

\section{BAURU}

2000 


\section{SANTOS, Carlos Neanes}

N261a Avaliação da reprodutibilidade interexaminadores na palpação muscular, após um programa de calibração / Carlos Neanes Santos.-- Bauru, 2000. $124 \mathrm{p}$ : il.; $29,7 \mathrm{~cm}$.

Dissertação (Mestrado) -- Faculdade de Odontologia de Bauru, USP

Orientador: Prof. Dr. Paulo César Rodrigues Conti

Autorizo, exclusivamente para fins acadêmicos e científicos, a reprodução total o parcial desta dissertação, por processos fotocopiadores e/ou meio eletrônico.

Assinatura do autor:

Data: 


\section{CARLOS NEANES SANTOS}

29 de junho de 1962

$1987-1989$

$1987-1988$

1998

$1998-2000$

Associações
Nascimento

Aracaju - SE

Curso de Especialização em Prótese

Dental, na Faculdade de Odontologia de

Bauru, Universidade de São Paulo.

Curso de Aperfeiçoamento em

Periodontia, pela PROFIS - Sociedade de

Promoção Social do Fissurado Lábio-

Palatal, Bauru - SP.

Professor do Departamento de Prótese do Curso de Odontologia da Universidade Federal de Sergipe

Curso de Pós-Graduação em Odontologia, área de Reabilitação Oral - Prótese, em nivel de Mestrado, na Faculdade de Odontologia de Bauru, da Universidade de São Paulo.

Associação Brasileira de Odontologia Secção de Sergipe 


\section{À Deus,}

por ter me concedido a vida, a oportunidade em descobri-la e pelos bons caminhos por onde me tem conduzido. 


\section{À meus pais, José dos Santos e Maria de Lourdes}

Santos, por terem me mostrado e ajudado a percorrer $o$

dificil caminho da vida; por tentarem me ensinar a distinguir

entre o bem e o mal; por terem me transmitido carinho e

amor, parte fundamental do bom relacionamento entre pais

e filhos; por serem bondosos, humildes e sinceros.

À meus irmãos e cunhados pelo incentivo, carinho e amizade.

Ao Sr. Luis Alves $e$ D. Herminia, de quem nunca faltaram palavras de amor e incentivo.

À minha esposa, Alaide por ter a paciência e vontade de me acompanhar na realização deste trabalho, e ainda poder e saber compartilhar os momentos dificeis e alegres que o destino nos reservou.

Obrigado por seu carinho e amor!

À minha adorável filha, Vanessa, que em seu sorriso, sempre presente ao meu lado, mesmo quando fisicamente ausente, iluminou minhas noites de estudo. Esperança de sempre continuar em frente...

De todo o coração, dedico este trabalho 
Existe um certo periodo na vida, que não sei como acontece, ou o porquê, mas alguém, não sei como, intervém na nossa caminhada, a ponto de alterá-la. Graças à Deus,

o Prof. Dr. Paulo César Rodrigues Conti assumiu este papel comigo.

...reclamou, mas não muito: "o suficiente", ensinou...

corrigiu...

incentivou...

enfim, orientou em tempo, e fora do tempo,

a ponto de hoje eu saber que ainda não sou o que deveria ser, mas, graças a Deus, não sou o que eu era...

Meu sincero agradecimento pela orientação precisa, experiente, sincera e amiga durante a elaboração deste trabalho. 
Ao Prof. Dr. José Valdez Conti, o meu agradecimento pela maneira carinhosa com que sempre me acolheu, pela oportunidade, incentivo e ensinamentos transmitidos. A minha eterna gratidão e respeito.

Aos Professores Dr. Waldyr Janson e Dr. Euloir Passanezi, de quem sempre terei em mente sua eterna disponibilidade e abnegação, marcando minha formação profissional com exemplos de dignidade, honestidade e competência.

Minha gratidão, respeito e carinho. 
Ao Prof. Dr. Luis Fernando Pegoraro, Presidente da Comissão de Pós-Graduação, da Faculdade de Odontologia de Bauru, da Universidade de São Paulo, pela oportunidade, incentivo e ensinamentos transmitidos, importantes na minha formação docente, profissional e pessoal.

Ao Prof. Dr. Gerson Bonfante, pelo senso crítico e coerência demonstrados em suas opiniões e pela seriedade com que conduz suas atividades profissionais.

Aos Professores do Departamento de Prótese da Faculdade de Odontologia de Bauru: Dr. Accácio Lins do Valle, Dr. Carlos Reis Araújo, Dr. Wellington Bonachela, Dr. Milton Carlos Gonçalves Salvador, Dr. Paulo Martins, Dr. José Henrique Rubo, Dr. Renato de Freitas, Dr. ${ }^{a}$ Eid Muniz Asckar e Dr. ${ }^{a}$ Lucimar Vieira,

pela dedicação, pelo trabalho em equipe e principalmente por terem me transmitido a importância de adotar uma filosofia de ensino. O meu reconhecimento e sinceros agradecimentos. 
Aos colegas e amigos do Curso de Mestrado:

Vinicius Janson (paulista), Nelsinho e Murilo (mineiros), Barnabé (goiano), Juliano (paranaense), Anuar (capixaba), Vinicius Porto (baiano), Mário (guatemalteco), pela alegria de compartilharmos os bons e os dificeis momentos em que passamos juntos durante todo o curso de Mestrado...

Em especial à Vagner Ortega, Daniela Castilio (paulistas), Leticia Borges (gaúcha), Andréa (carioca) e Sérgio Sábio (paranaense), pela preciosa colaboração que me deram na elaboração deste trabalho, participando dos experimentos como examinadores

Aos colegas e amigos do Curso de Doutorado:

Luciano, Henrique, Materson, Daniel, Sérjão, Luis Ramos e João Evandro, com os quais pude compartilhar, durante anos, informaçòes. Meus sinceros agradecimentos...

Aos colegas e amigos do estágio: Andreza, Paulo, Renato, Márcio, Estela, Rafael, Carolina, Fábio e Patricia, aos colegas dos cursos de Pós-Graduação em Dentística, Ortodontia, Periodontia, Odontopediatria, Cirurgia, Diagnóstico Oral, Patologia, Endodontia e Materiais Dentários, pelo convivio durante todos estes anos de pós-graduação...

A todos os funcionários do Departamento de Prótese da FOB-USP: Débora, Reivanildo, Angela, Luzia, Edna, Lilian, Marcelo, Geraldo e Didi, por toda atenção, gentileza e carinho a mim dispensados durante estes anos... 
À Faculdade de Odontologia de Bauru, da Universidade de São Paulo, representada pelo seu Diretor, Prof. Dr. Aymar Pavarini e Vice-Diretor, Prof. Dr. Clóvis Monteiro Bramante.

Ao Programa Institucional de Capacitação de Docentes da CAPES, pelo apoio financeiro para a realização do curso de Pós-Graduação.

Aos funcionários da Pós-Graduação: Ana, Cleusa, Débora, Giane, Heloisa e Neide, pela atenção, convivio e amizade; e aos funcionários da Associação de Pós-Graduandos, Salvador e André, pela presteza e dedicação.

Aos funcionários da biblioteca: Maria Helena, Célia, Cybelle, Ana Paula, Rita, César, Marcelo, Ademir, Maria, Valéria, Jane e Mônica, que sempre me auxiliaram de forma prestativa e amiga. O meu muito obrigado...

Ao Serviço de Triagem da Faculdade de Odontologia de Bauru, USP, representado por essa pessoa amiga, Leucy, ao proporcionar a condição para seleção dos pacientes, passo fundamental para a parte experimental da pesquisa.

À amiga Fátima pela dedicação e empenho com que realizou a estrutura deste trabalho.

Ao Prof. José Roberto Lauris, pela ajuda na estatística e à Prof. $^{\boldsymbol{a}}$ Eloísa pela leitura e pelas correções suplementares deste trabalho. 


\section{AGRADECIMENTOS ESPECIAIS}

Aos meus irmãos Jeanne, Osman e Osanan, por terem me apoiado e incentivado na carreira universitária.

À Luis Herminio A. de Oliveira e Urbino Tunes, pela sinceridade, atenção e valiosa amizade.

A minha amiga Rosa, que com sua maneira de ser, alegre, expontânea, carinhosa e humana, passou a ser merecedora de minha sincera amizade.

Aos amigos sempre fiéis, Luciano Brandão, de Aracaju, Augusto César de Belém e Jório da Escóssia de Fortaleza, que me deram sempre apoio nos momentos tristes e alegres de minha vida.

Ao amigo André Lucas, pelo apoio e carinho a mim dispensados.

Aos amigos e companheiros de trabalho, Pacheco, Luis Carlos, Fátima, Anuska, Patricia, Hermenegildo, Edvaldo, Ivana, Marta, Selma, Marabeau, Maira, Maria Helena, Amanda, Fernanda e Adriano, cujos incentivo e apoio sempre me estimulam a seguir em frente.

Ao Tribunal de Justiça do Estado de Sergipe, na pessoa de seu presidente Des. Gilson Góes Soares, pelo apoio na conclusão deste Mestrado. E de uma maneira muito especial, à pessoa do Des. José Barreto Prado, a quem dispenso afeição e carinho paternos, e a quem também dedico parte deste meu trabalho. 
À todos meus professores do Curso de Graduação da Faculdade de Odontologia da Universidade Federal de Sergipe, que certamente, em muito contribuiram para a minha formação profissional.

À todo corpo docente da Faculdade de Odontologia da Universidade Federal de Sergipe, pelo incentivo e confiança em mim depositados, em especial à Prof. ${ }^{\boldsymbol{a}}$ Edith Bastos.

À Universidade Federal de Sergipe, na pessoa do Magnífico Reitor Prof. Dr. José Fernandes de Lima.

À Pró-Reitoria de Pós-Graduação e Pesquisa da Universidade Federal de Sergipe na pessoa do Prof. Dr. José do Patrocínio, pelo apoio fundamental durante a realização deste curso.

À Coordenadora de Assuntos Internacionais e Capacitação Docente e Técnica, Prof. ${ }^{a}$ Neuza Maria G. Ribeiro.

Aos colegas da Associação Brasileira de Odontologia - Secção de Sergipe, representado pelo seu presidente Dr.Manuel Barreto

Ao Conselho Federal de Odontologia - Secção de Sergipe, representado pelo seu presidente Dr. Marcos Macedo.

Ao Diretor da EAP, Dr.Tadeu Augusto.

À todos os funcionários da Faculdade de Odontologia de Bauru, da Universidade de São Paulo, que com boa vontade e dedicação, atendem com gentileza às nossas solicitações.

Aos funcionários do Instituto de Ensino Odontológico, Edson, Mariluci, Daniela, Renata, Rosana e D. Tereza, pela dedicação e respeito.

Meu muito obrigado!! 
À todos amigos que, direta ou indiretamente, contribuiram para a realização desta conquista.

O meu muito obrigado! 


\section{SUMÁRIO}

LISTA DE FIGURAS .......................................................................................... xiv

LISTA DE TABELAS ………………………………..................................... $\mathrm{xV}$

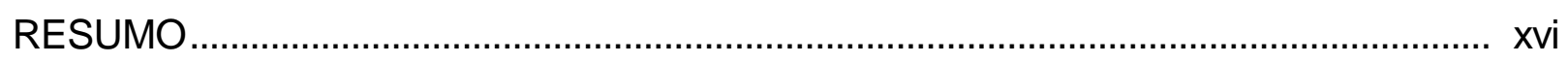

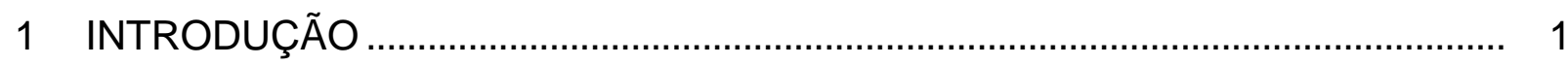

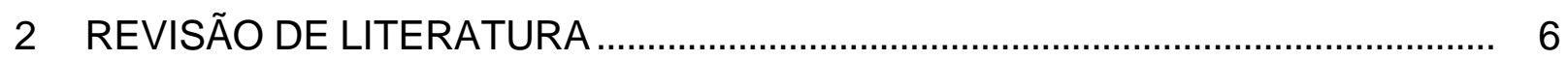

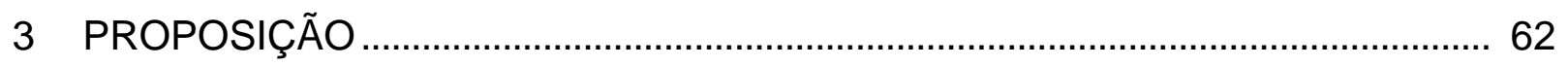

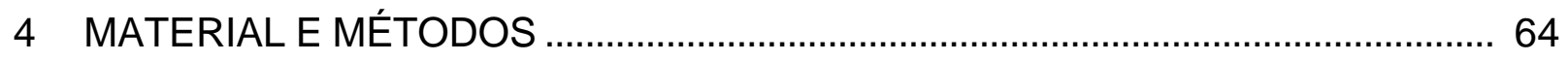

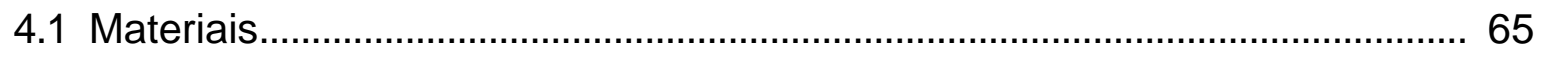

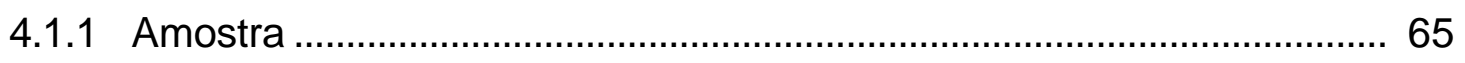

4.1.2 Fichas utilizadas para a pesquisa ..................................................... 66

4.1.3 Examinadores ...................................................................................... 76

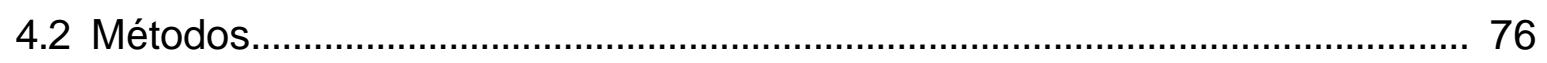

4.2.1 Treinamento e calibração dos examinadores ......................................... 76

4.2.2 Procedimento do exame ...................................................................... 77

4.2.3 Análise estatística................................................................................. 78

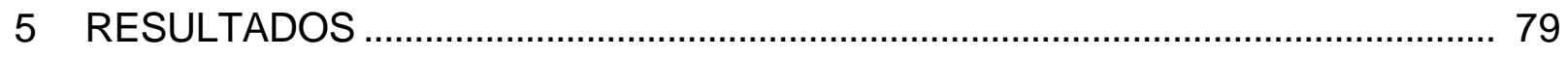

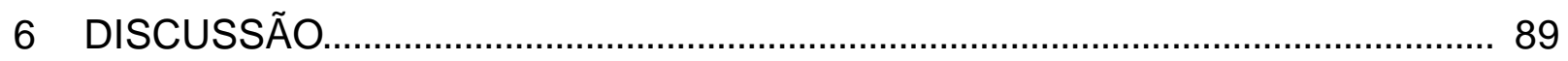

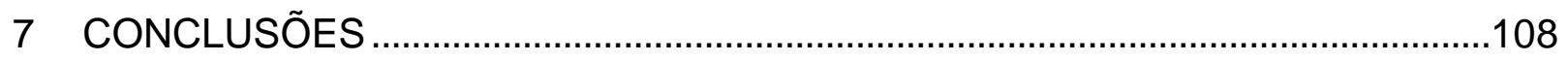

REFERÊNCIAS BIBLIOGRÁFICAS .......................................................................110

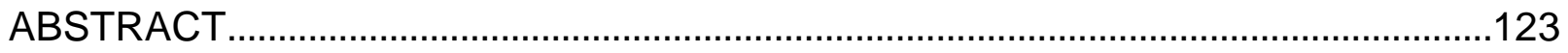




\section{LISTA DE FIGURAS}

FIGURA 5.1 - Valores de concordância interexaminadores para os diversos músculos investigados nas três sessões de exame.

FIGURA 5.2 - Concordância interexaminadores para o músculo Masséter Profundo nos três exames realizados

FIGURA 5.3 - Concordância interexaminadores para o músculo Masséter Superficial nos três exames realizados

FIGURA 5.4 - Concordância interexaminadores para o músculo Temporal nos três exames realizados

FIGURA 5.5 - Concordância interexaminadores para o músculo Esternocleidomastoideo nos três exames realizados

FIGURA 5.6 - Variação da concordância geral interexaminadores nos diferentes exames realizados

FIGURA 5.7 - Concordância interexaminadores em relação ao lado direito e esquerdo 


\section{LISTA DE TABELAS}

TABELA 5.1 - Resultado médio das escalas de análise visual (EAV) durante as três avaliações.

TABELA 5.2 - Valores médios do Teste de Kendall para os músculos nas três sessões de exame $(p<0.05)$

TABELA 5.3 - Valores de concordância (W) para o exame do músculo Masséter Profundo Direito e Esquerdo $(p<0.05)$

TABELA 5.4 - Valores de concordância (W) para o músculo Masséter Superficial: origem (D e E), corpo (D e E), inserção (D e E) $(p<0.05)$

TABELA 5.5 - Valores de concordância (W) para o músculo Temporal: Anterior ( $D$ e $E$ ); Médio ( $D$ e E) e Posterior ( $D$ e $E$ ) $(p<0.05)$

TABELA 5.6 - Valores de concordância (W) para o músculo Esternocleidomastoideo: Superior, Médio e Inferior $(p<0.05)$

TABELA 5.7 - Valores médios gerais do Teste de Kendall, registrados na concordância interexaminadores durante a realização dos três exames

TABELA 5.8 - V Valores de concordância $(W)$ em relação aos lados direito e esquerdo $(p<0.05)$ 


\section{RESUMO}

O objetivo deste estudo foi avaliar a concordância interexaminadores na palpação muscular, após um programa de calibração, assim como, determinar as variações dessa concordância em relação ao tempo, a determinado músculo e ao lado palpado.

Para tal, utilizou-se uma amostra de 32 indivíduos, proporcionalmente divididos em relação ao sexo, escolhidos aleatoriamente nas diversas clínicas (dores orofaciais, prótese, periodontia, cirurgia e dentística) da Faculdade de Odontologia de Bauru, da Universidade de São Paulo. Esta amostra foi dividida em dois grupos: sintomático, composto por 16 indivíduos que apresentavam sinais e sintomas de DTM, com queixas compatíveis com patologias de origem muscular e, assintomático, composto por 16 indivíduos, sem queixas de sintomas de DTM.

Os exames de palpação foram realizados por quatro examinadores, previamente treinados, utilizando-se um programa de calibração, que consistiu de instruções detalhadas relativas ao exame, demonstração da localização dos músculos e da força exercida durante a palpação. Foram realizados 3 exames: inicial, intermediário (30 dias após) e final (45 dias após o início da pesquisa), utilizando-se músculos de mastigação (Masséter e Temporal) e cervical (Esternocleidomastoideo).

A análise de presença ou severidade de resposta do paciente foi feita através de uma escala ordinal de 0 a 3.

Apesar da presença de variáveis inerentes à análise da dor, como a oscilação dos sinais e sintomas do paciente, diferenças na reação do indivíduo e na interpretação da dor do paciente pelo examinador, verificou-se, através do teste de concordância de Kendall, que o programa de calibração foi efetivo na obtenção de concordância interexaminadores, obtendo-se valores entre 0.56 (origem do Masséter Superficial) e 0.84 (Esternocleidomastoideo Médio), considerados de aceitáveis a 
excelentes. O tempo não alterou essa concordância não havendo, também, diferenças na concordância entre os diversos músculos, assim como para o lado palpado.

Concluiu-se que programas de calibração podem ser efetivos na padronização da palpação muscular, o que credencia tal procedimento como uma importante etapa no exame das Disfunções Temporomandibulares. 
1 INTRODUÇÃO 


\section{INTRODUÇÃO}

As Disfunções Temporomandibulares (DTM) englobam uma série de sinais e sintomas envolvendo a musculatura mastigatória, a articulação temporomandibular (ATM) ou ambas ${ }^{65,79}$.

Apesar de estudadas há muito tempo, muitas controvérsias ainda existem em relação à etiologia, diagnóstico e tratamento dessas disfunções.

Definir as condições patológicas que produzem dor e disfunção músculoesqueletais no sistema estomatognático não é uma tarefa fácil. Essa dificuldade de definição surge da mudança de conceitos em relação às DTM e da incapacidade de se identificarem fatores etiológicos claros. Isso também ocorre devido ao fato de que os pacientes de DTM não constituem um grupo homogêneo, mas sim vários subgrupos distintos, apresentando uma variedade de sinais e sintomas. Entre os sinais clínicos mais característicos das DTM estão a sensibilidade muscular e articular à palpação, sons articulares e limitação e/ou dificuldade de movimento mandibular. A detecção e a correta interpretação desses achados passam a ser, então, uma necessidade para a elaboração de um correto diagnóstico e plano de tratamento.

Desses sinais e sintomas citados anteriormente, relacionados à DTM, a dor orofacial é a principal razão pela qual os pacientes procuram tratamento, sendo que, em muitos casos, a eficácia do tratamento é medida pelo alívio da dor.

Parece haver unanimidade na literatura de que um diagnóstico incorreto é uma das mais freqüentes causas de insucesso do tratamento de pacientes com DTM, onde muitas vezes há a necessidade de se reconhecerem condições patológicas associadas. 
Os métodos de exame do paciente de DTM têm-se alterado drasticamente com o passar do tempo. No início dos anos 30, COSTEN $^{12}$ relatou que a perda dos dentes posteriores levava o côndilo a pressionar as estruturas retrocondilares (nervo timpânico e vasos aurículo-temporais), ocasionando dor na região do ouvido e cabeça, zumbidos, secura na boca e ruídos articulares. Esse conjunto de sintomas foi determinado "Síndrome de Costen", sendo enfatizada a participação das anormalidades oclusais na etiologia desses problemas.

Nas décadas de 50 e 60, com o advento de um conhecimento maior do fenômeno psicofisiológico e do estresse, o conceito das doenças induzidas psicofisiologicamente foi defendido. SCHWART ${ }^{88}$ introduziu o termo "Síndrome DorDisfunção da Articulação Temporomandibular", ao afirmar que a causa dessas alterações era primariamente a disfunção dos músculos mastigatórios. Já LASKIN ${ }^{56}$, introduzindo a "Teoria Psicofisiológica", enfatizou a influência de hábitos parafuncionais como um dos fatores causais da hipersensibilidade muscular. A partir daí surgiu o termo "Síndrome Dor-Disfunção Miofascial", ainda hoje utilizado por muitos para descrever essas alterações. Com esses novos modelos causais da doença, o exame do paciente com DTM mudou de um caráter meramente oclusionista para uma avaliação mais detalhada dos músculos e da ATM, associado a uma anamnese mais completa dos fatores de distúrbios emocionais na vida do paciente.

$\mathrm{Na}$ década de 70 , os conceitos da medicina ortopédica e da fisioterapia ganharam popularidade no tratamento das DTM. Isso reforçou a importância da avaliação dos músculos, articulações e análise do movimento mandibular como parte do exame. Estes procedimentos levaram-nos aos procedimentos de exame atuais que, além de história médica completa e entrevista do paciente, envolvem um exame físico do movimento mandibular, uma avaliação neurológica, psicológica, exame dos dentes e finalmente um criterioso exame dos músculos de cabeça, pescoço e da ATM com o auxílio da palpação, com propósito de verificar a presença de dor e sensibilidade. Sabese que essas patologias acometem comumente a ATM, a musculatura mastigatória ou ambas. 
Para definir uma patologia referente especificamente àATM é necessário o estabelecimento de critérios que levem a uma classificação específica e um plano de tratamento adequado. Por exemplo, para o diagnóstico de deslocamento do disco com redução é normalmente necessária a presença de ruídos articulares detectados pela inspeção manual e pela detecção de movimentos irregulares definidos pelo exame clínico. Porém, para se ter a certeza de que existe realmente um deslocamento do disco, o profissional pode lançar mão de técnicas de imagem de alta precisão na localização do disco, como a ressonância magnética.

Por outro lado, para o diagnóstico de dor miofascial, mialgia e outras síndromes da dor muscular, o clínico deve determinar um diagnóstico baseado no exame físico e anamnese. Essas metas são alcançadas primariamente pela palpação, testes de provocação e registro da movimentação mandibular ativa.

A palpação manual é o método clínico mais amplamente utilizado para avaliar a dor muscular. É considerada como uma importante parte do processo de exame clínico $^{33,34}$, embora muitas poucas diretrizes técnicas específicas existam para permitir aos clínicos e pesquisadores, a sistematização e padronização dos procedimentos técnicos de palpação.

Para assegurar confiabilidade dos dados coletados, a padronização do exame é essencial, sendo a calibração interexaminadores o melhor meio de se obter essa confiabilidade.

Vários estudos têm sido desenvolvidos com a finalidade de avaliar a confiabilidade e reprodutibilidade dos métodos de palpação em função do grau de concordância inter e intra-examinadores, mas os resultados têm sido muito controvertidos. Geralmente a confiabilidade da sensibilidade muscular e da articulação é julgada pela consistência da resposta do paciente ou reação à palpação ${ }^{33}$, ou seja, os pacientes são solicitados a diferenciar entre pressão e dor, indicar a dor associada à palpação marcando numa escala análoga visual que vai de 0 a $100 \mathrm{~mm}$, ou avaliar sua dor numa escala ordinal de 0 a 3. 
Apesar de subjetiva, essa avaliação é de fundamental importância para o estabelecimento de correto diagnóstico, assim como para acompanhamento do resultado de tratamentos propostos.

Baseado nisso, fica clara a necessidade de avaliar se métodos de treinamento profissional são efetivos na padronização de procedimentos em relação à palpação muscular.

Portanto, o propósito desta pesquisa é avaliar a reprodutibilidade interexaminadores na palpação da musculatura mastigatória após um programa de calibração. 
2 REVISÃO DE LITERATURA 


\section{REVISÃO DE LITERATURA}

O termo Disfunção Temporomandibular define uma série de sinais e sintomas relacionados à musculatura mastigatória, à articulação temporomandibular (ATM) ou ambos. ${ }^{65,79}$

Apesar de conhecida e estudada há muito tempo, tal patologia tem ganhado um papel de destaque nas ciências médicas e odontológicas ultimamente.

Nesta revisão de literatura mantém-se a terminologia original de cada trabalho, em função das várias denominações utilizadas durante as diferentes épocas em que se deu a pesquisa.

A preocupação com os problemas articulares já foi descrita no século $V$ a.C., quando Hipócrates descreveu um método para reduzir o deslocamento da mandíbula, muito parecido com as técnicas atuais e similar àquele usado pelos antigos egípcios 2.500 anos antes. Os primeiros conceitos não foram bem desenvolvidos, até os estudos anatômicos da articulação da mandíbula e crânio se tornarem mais aperfeiçoados. Sobressaíram-se nesses estudos Leonardo Da Vinci (século XV), Andreas Vesalius (século XVI) e John Hunter (século XVIII). ${ }^{69}$

Em 1918, PRENTISS ${ }^{82}$ introduziu a teoria do deslocamento mecânico da mandíbula em que a perda de dimensão vertical era responsável pela disfunção da ATM. Ainda segundo o autor, o fechamento excessivo da mandíbula, devido à perda de contenção dos posteriores, levaria a uma compressão do côndilo nas áreas de ATM.

Historicamente, uma das maiores contribuições para os estudos nessa área foi dado por COSTEN ${ }^{12}$ que, em 1934, considerou as alterações oclusais como a causa das dores musculares e do ouvido relatada pelos pacientes, devido à perda dos 
dentes posteriores que levava o côndilo a pressionar estruturas retrocondilares (nervo timpânico e vasos aurículo-temporais), ocasionando dor na região do ouvido, dor de cabeça, zumbidos, secura na boca e ruídos articulares. Esse conjunto de sintomas foi determinado "Síndrome de Costen". Seus estudos foram baseados em observações realizadas em 11 pacientes que apresentavam os sintomas acima citados.

Parece ter sido LIBMAN ${ }^{59}$, ainda em 1934, o primeiro autor a escrever um artigo sobre sensibilidade dolorosa, quando descreveu um método simples de avaliar a sensibilidade individual de dor por pressão no processo estilóide. Essa foi a primeira tentativa de representação objetiva do fator sensibilidade em relação aos sintomas do paciente. O autor mediu a sensibilidade pressionando o polegar contra o osso mastóide e, então, deslizou o dedo em direção ao processo estilóide, pressionando-o. A pressão no osso mastóide normal não causou dor e, portanto, serviu como um controle. Essa pressão foi dolorosa para alguns e para outros não. Com esse teste, as pessoas foram classificadas em 3 grupos: 0 sensível, sem evidência de dor; + sensível, com evidência de pouca dor; +++ sensível, com evidência de dor marcante. Segundo o autor, esse teste foi considerado útil na avaliação dos sintomas.

O anatomista SICHER $^{89}$, em 1948, discordou da idéia de que o côndilo pudesse pressionar o nervo timpânico, alegando que somente em casos de fratura ou perfuração da tábua óssea o côndilo teria condições anatômicas de alcançar o tímpano, uma vez que existe a fossa condilar separando essas estruturas.

Em 1952, HARDY; WOLFF; GOODELLP9 ${ }^{\beta 9}$ expuseram sucintamente as exigências de um método adequado de mensuração do limiar de dor, entre os quais: mensurabilidade do estímulo com reprodutibilidade, controle adequado do limiar e do limite máximo, não causar danos ao tecido, produção de uma percepção nítida de dor, simplicidade do aparelho e no método de aplicação. Segundo o autor, o uso do dedo oferece amplamente essas condições, com exceção da mensuração da dor, a qual pôde ser medida com o uso do algômetro. 
De acordo com KEELE ${ }^{49}$, em 1954, deve-se dar condições de tranqüilidade e relaxamento ao paciente para a medição do limiar de dor à pressão (LDP). Não se deve permitir que o procedimento ou instrumento transmita qualquer impressão de ameaça ao paciente. Assim, na aplicação de um estímulo de pressão, o fator tempo deve ser padronizado a fim de que a taxa de aumento seja constante. Nesse caso, a pressão é aplicada a uma taxa de $1 \mathrm{~kg}$ aumentada por segundo, permitindo que a escala seja ascendida ao valor limiar com um mínimo de fadiga ao paciente e ao examinador, em segundos. O autor aplicou o teste de Libman (dedos) e o teste de dor à pressão algômetro) em 260 pessoas e as classificaram como hipersensíveis (sensibilidade com força até 1,5kg); normo-sensíveis (pressão de 2,0 - 4,0kg); hiposensíveis (pressão com valores acima de 4,0kg). O autor concluiu que o principal problema do teste de Libman para a sensibilidade de dor foi a falta de mensuração do estímulo, o que foi superado pelo uso do algômetro.

Em 1955, SCHULTZ ${ }^{87}$ defendeu que a etiologia das DCM seria atribuída a problemas na própria ATM, como frouxidão dos ligamentos e hipermobilidade articular.

Nesse mesmo ano, SCHWARTZ ${ }^{88}$ atribuiu um papel primário a fatores psicogênicos, e às alterações oclusais um papel secundário. Segundo o autor, a síndrome se manifestava sob forma de uma incoordenação funcional dos músculos com sintomas de estalos na articulação, subluxações ou deslocamentos recorrentes. A esses sintomas seguia-se, em muitos casos, o espasmo dos músculos mastigatórios que se caracterizava pela limitação dolorosa dos movimentos mandibulares. O autor propôs o termo "Síndrome Dor-Disfunção da Articulação Temporomandibular".

Um artigo referente ao "erro do observador" na Medicina foi escrito em 1968 por OLDHAM ${ }^{76}$. Para o autor, essa expressão talvez seja deselegante, o que cria uma implicação, talvez injustificada, potencialmente enganosa, devido à importância desse erro levar à inúmeros questionamentos. Segundo o autor, em pouquíssimas ocasiões o mecanismo preciso de um erro do observador tem sido investigado. E isso é importante para que se possa evitar, sem crítica, um julgamento 
num conjunto de circunstâncias. Além disso, esse mecanismo pode acrescentar informações valiosas para o conhecimento e entendimento.

DAVENPORT ${ }^{14}$, em 1969, estudou os limiares de dor à pressão na cavidade oral do homem. Para tal estudo foram utilizados 10 indivíduos (estudantes de odontologia) com idade média de 20,7 anos. Os testes foram sempre executados pelo mesmo operador, utilizando um algômetro. A medição do tecido mucoperiósteo foi feita com uma sonda. As mensurações foram repetidas em intervalos semanais de 4 semanas. Os limiares de dor à pressão variaram significativamente entre os indivíduos, mas não no mesmo indivíduo em diferentes ocasiões. Foi descoberto que a taxa de aplicação e a espessura do tecido influenciam consideravelmente os limiares de dor à pressão. Uma taxa uniforme de aplicação do estímulo não necessariamente garante, portanto, o controle desse fator quando os limiares de dor à pressão dos indivíduos estão sendo comparados.

Nesse mesmo ano, LASKIN" ${ }^{56}$ introduziu a "Teoria Psicofisiológica" em que o espasmo muscular poderia ser causado de três maneiras diferentes: sobreextensão, maior contração ou fadiga muscular. Segundo o autor, a causa mais comum seria a fadiga muscular causada por hábitos orais crônicos (apertamento dos dentes e bruxismo), os quais representariam mecanismos de liberação de tensão. Dessa forma explica-se que a maioria dos casos envolve mais o aspecto emocional do que fatores mecânicos. Segundo sua teoria, o espasmo muscular leva à dor, limitação e também a uma leve mudança na posição da mandíbula, gerando uma oclusão incorreta. Caso essa alteração na posição mandibular se prolongue, poderá ocorrer uma acomodação dos dentes, explicando como as desarmonias oclusais podem surgir em uma dentição funcional como o resultado do problema, e não como a causa do mesmo. Ainda de acordo com o autor, o bruxismo pode ser citado como sendo um dos fatores causais das disfunções, uma vez que gera uma hiperatividade muscular e, conseqüentemente, a fadiga muscular. Portanto, o autor considerou que o espasmo dos músculos mastigatórios seria responsável pelos sintomas do paciente, propondo o termo "Síndrome Dor-Disfunção Miofascial” para englobar tais sintomas. 
BOHL; KNAP², em 1974, fazendo uma avaliação do relacionamento oclusal e disfunção da ATM, através da palpação, verificaram que a seqüência e força de contração dos músculos masséter e temporal fornecem informações importantes no tocante às relações maxilomandibulares e o esquema oclusal. Para isso, uma seqüência de exame de 12 passos deve ser feita, começando pela palpação da ATM, da porção profunda do músculo masséter, borda anterior e inferior do masséter superficial, as porções anterior, médio e posterior do temporal, o pterigóideo medial, o feixe posterior do músculo digástrico, o esternocleidomastóideo e os músculos occipitais. Palpação intra-oral da inserção do músculo temporal e feixe inferior do pterigóideo lateral completariam o exame. Segundo os autores, os músculos devem ser avaliados na textura, consistência e volume, assim como sua força e seqüência de contração. As regiões de dor são localizadas usando o dedo médio de cada mão, com o dedo indicador e anelar sendo usados para examinar as regiões que estão subjacentes à região primária da palpação. A pressão suave, mas firme, é essencial na palpação digital da musculatura, sendo o paciente instruído a relaxar sua mandíbula, com os dentes separados. Segundo os autores, um dos mais confiáveis indicadores da presença de uma região dolorosa é o reflexo da pálpebra ou piscar de olhos. Os autores ainda comentaram que as fibras da porção profunda do músculo masséter nos pacientes com bruxismo, associado a contatos oclusais deflectivos na posição de relação cêntrica ficam dolorosos. Os autores relataram ainda que as fibras anteriores do músculo temporal, que são considerados elevadores da mandíbula, são muito sensíveis às interferências oclusais, juntamente com a sua inserção. Já o músculo pterigóideo lateral pode ser sensível se o paciente possui um contato deflectivo no lado de balanceio e se tem limitação de abertura da mandíbula.

Com o objetivo de investigar a constância de sinais clínicos em pacientes com DTM, KOPP ${ }^{52}$, em 1977, selecionou 34 pacientes com DTM os quais foram avaliados duas vezes pelo próprio autor. O exame clínico dos pacientes incluía os músculos mastigatórios, a ATM e a capacidade de movimento da mandíbula. O índice de disfunção clínica (Di) foi calculado como uma medida do grau de disfunção mandibular. Pelo exame de palpação, verificou que houve uma concordância em relação à sensibilidade de $78 \%$ para o músculo pterigóideo medial; $56 \%$ para o 
masséter superficial; 81\% masséter profundo; 47\% pterigóideo lateral; 46\% para o temporal anterior e 46\% para a inserção do temporal. A concordância para a sensibilidade à palpação dos músculos mastigatórios, movimentos limitados, sons da ATM e dor durante o movimento foi bem baixa. O autor concluiu que todos os sinais clínicos examinados, exceto para abertura máxima da boca e protrusão máxima, mostraram uma baixa constância num período de 6 semanas (a abertura máxima da boca foi o parâmetro clínico investigado mais confiável com relação à constância para uso na avaliação do tratamento).

SMITH $^{90}$, em 1977, avaliou se dois examinadores concordavam ou discordavam dos sinais e sintomas observados nos mesmos indivíduos. Para tal estudo, utilizou-se um grupo de pacientes composto por 50 indivíduos com sinais e sintomas de DTM, que incluía 39 mulheres e 11 homens, com idade média de 28,8 anos (16 - 55 anos), e um grupo de estudantes composto por 50 alunos do curso de Odontologia, que incluía 25 mulheres e 25 homens com idade média de 19,4 anos (16 - 31 anos). Ambos os grupos foram examinados independentemente por dois observadores: o grupo de pacientes com intervalo de 15 minutos e o grupo de estudantes com intervalo de vários dias. Os observadores foram nominados de A e B. O primeiro, um consultor de cirurgia dental, e o segundo um assistente de cirurgia dental. Ambos trabalharam juntos por 8 anos e apresentavam uma considerável experiência no exame de pacientes com DTM. A dor era classificada pela resposta à pergunta "Este movimento é doloroso?" como positiva ou negativa; o barulho era julgado pela palpação enquanto a auscultação da ATM e os movimentos avaliados por critérios estabelecidos. No grupo de pacientes, os observadores registraram sinais e sintomas em todos os pacientes, porém houve desacordo total em 5 indivíduos. Nos 45 restantes, apesar de haver freqüentes desacordos, cada observador registrou sinais e sintomas isolados que não foram notados pelo outro. Isto resultou num erro considerável do observador. Neste grupo, houve mais concordância no movimento de abertura. No grupo de estudantes, 26 indivíduos foram considerados como livres de sintomas. Dentre os 24 restantes, o observador A designou 20 indivíduos como afetados, sendo que o observador $B$ julgou que 14 estavam nessa condição. Os resultados mostraram que os observadores foram mais concordantes na análise do 
grupo de pacientes do que com o grupo de estudantes. A repetibilidade das observações foi pobre no grupo estudante. Portanto, é bem conhecido que até mesmo os observadores experientes variaram em suas interpretações dos mesmos fenômenos e um observador pode registrar interpretações diferentes da mesma evidência com o passar do tempo. Nenhum teste objetivo confiável para um diagnóstico firme de DTM está disponível. Isso pode ter pouca consequência no tratamento de pacientes com DTM, mas quando uma pesquisa for realizada um possível erro do observador deve sempre ser considerado.

A fim de que fosse avaliada a confiabilidade interexaminadores no julgamento de cáries, JOSEPH et al. ${ }^{48}$, em 1979, utilizaram dois examinadores e um grupo de 60 crianças. O treino intensivo de dois dias e sessões de padronização obtiveram sucesso com um grau excelente de consistência no registro das superfícies cariadas e obturadas.

MCNEILL et al. ${ }^{66}$, em 1980, notaram que existiam patologias mais abrangentes e que o termo "Síndrome da Dor e Disfunção Mandibular" era restrito. Propuseram o termo Desordens Craniomandibulares (DCM) e uma classificação para tais problemas, envolvendo tanto as desordens extra-articulares, relacionadas aos distúrbios musculares, como as desordens intra-articulares, envolvendo a ATM.

WEINBERG ${ }^{103}$, em 1980, relata que uma história detalhada da dor em outras partes da cabeça, pescoço, ombros e costas, deve ser feita em virtude de grande parte dos pacientes com DTM apresentarem um envolvimento muscular nessa regiões. Ainda segundo o autor, os músculos pterigóideo lateral, inserção do temporal e masséter estão mais freqüentemente envolvidos em pacientes com Desordens Temporomandibulares do que os outros músculos mastigatórios.

Também em 1980, JOHNSTONE; TEMPLETON ${ }^{47}$ avaliaram a viabilidade de palpar o músculo pterigóideo lateral e chegaram à conclusão de que embora a disfunção do músculo pterigóideo pudesse contribuir para que ocorresse dor em pacientes com DTM, a palpação diretamente sobre esse músculo não poderia ser efetuada sem aplicar pressão no músculo pterigóideo medial, devido a sua 
localização. Além disso, a mera palpação, se agressiva o bastante, poderia elicitar dor em outras regiões, confundindo com a sensibilidade do pterigóideo lateral. A possibilidade de confundir a hipersensibilidade de inserção do músculo temporal também foi cogitada.

Nesse mesmo ano, CARLSSON et al. $^{5}$ avaliaram as variações intra e interexaminadores no exame do sistema mastigatório. Para isso, três dentistas $(A, B$, e C) participaram do estudo que continha 4 partes: a) independente um do outro, os examinadores A e B examinaram 22 crianças com 11 anos, aleatoriamente selecionadas de um grupo de 402 crianças, b) independente um do outro, os examinadores B e C examinaram 30 adultos (idade 16-83 anos, média = 41) selecionados aleatoriamente de um grupo de 124 indivíduos, c) as 22 crianças de 11 anos do grupo "a" foram examinadas pelo examinador A em 2 ocasiões em um intervalo de 5 semanas e d) 63 pacientes foram examinados pelo examinador $\mathrm{C}$ em 2 ocasiões com 1 intervalo de 1 ano. Foram usados métodos de exame clínico de rotina, do Departamento de Odontologia de Chicago, que incluia medições de variações do movimento mandibular, função de ATM, palpação dos músculos mastigatórios e da ATM, bem como exame dos pacientes com dor ao movimentar a mandíbula. As diferenças interexaminadores foram relativamente pequenas quando a capacidade do movimento mandibular foi medida. Registros repetidos executados após 5 semanas no grupo de crianças mostraram alta concordância, enquanto consideráveis variações para a mobilidade mandibular e o índice de disfunção clínica foram encontradas com um intervalo de 1 ano no grupo adulto. Em relação à palpação da ATM e músculos mastigatórios, houve uma concordância interexaminadores de 82 a 100\% (média 95\%) no grupo de crianças, uma concordância de $80 \%$ para a palpação muscular e $93 \%$ para a palpação articular no grupo adulto. Quanto ao registro dos contatos prematuros, a concordância entre os examinadores foi relativamente boa. Os resultados do presente estudo indicaram que a concordância intra e interexaminadores é boa o bastante para permitir comparações entre diferentes estudos executados por experientes observadores usando a mesma técnica. 
MOODY et al. ${ }^{73}$, em 1981, fazendo uma relação do estresse em pacientes com Síndrome Dor Disfunção Miofascial (SSDMF) e sem disfunção miofascial, verificaram que aqueles pacientes com SSDMF experimentaram níveis significativamente mais altos de dor e estresse do que os do grupo controle, aumentando a crença de que o fator estresse pode ser um fator contribuinte na etiologia de tais processos dolorosos. Contudo, foi descoberto dentro de ambos os grupos que não existem relações significativas entre o estresse e as medidas subjetivas de dor.

Em 1982, FRIEDMAN; WEISBERG ${ }^{29}$, analisando as dificuldades da palpação muscular no diagnóstico da ATM, concluíram que a palpação dos músculos para detectar sensibilidade pode fornecer muitas informações erradas pelas seguintes razões: a) a palpação muscular não distingue entre patologia muscular local e dor reflexa; b) alguns músculos (trapézio e esternocleoidomastóideo) têm cadeias de linfonodos localizados na face medial do feixe muscular. Se esses nódulos estão inflamados devido a infecções, eles serão sensíveis se palpados; c) as articulações inflamadas sob um músculo podem ser confundidas com a patologia muscular; d) a glândula parótida inflamada pode ser confundida com a sensibilidade do masséter. Portanto, segundo o autor, o teste muscular isométrico é um procedimento de diagnóstico mais confiável do que a palpação muscular. Além disso, esse procedimento pode ser utilizado para avaliar os músculos que são altamente significativos na disfunção da ATM e ainda inacessíveis à palpação.

Em sua conferência, como presidente da Associação Americana de Odontologia, numa reunião à respeito de etiologia, diagnóstico e tratamento de Desordens Temporomandibulares, GRIFFITHS ${ }^{37}$, em 1983, relatou que, embora a ocorrência das Desordens Temporomandibulares possa não ser recente, essas patologias constituem uma área de pesquisa e estudo relativamente nova. Como resultado, existem poucas, talvez nenhuma, abordagem padronizada ou organizada do exame, diagnóstico ou tratamento das DTM. Ainda segundo o autor, os participantes dessa conferência propuseram que, além de se obter uma história dental e médica completa e realizarem um exame dental detalhado em todos os pacientes, 
uma breve história de sintomas pertinente às DTM deve ser feita em todos os pacientes para possibilitar ao profissional determinar a necessidade de uma avaliação mais detalhada. Se a história de sintomas e do exame resultarem em descobertas positivas, os autores recomendam uma segunda avaliação mais completa, especialmente relacionada à avaliação de DTM.

FLEISS; CHILTON ${ }^{25}$, em 1983, avaliaram o grau de concordância interexaminadores na mensuração da doença periodontal. Para isso, foram utilizados dois examinadores que, separadamente, avaliaram em dois estágios 26 pacientes com relação a seis sinais de doença periodontal: recessão gengival, mobilidade do dente, presença de tártaro, profundidade da bolsa, inflamação gengival e acúmulo de placa. Entre os 2 estágios os examinadores foram calibrados. Os resultados mostraram que, apesar das variabilidades interexaminadores no primeiro estágio, houve um aumento bastante significante nos valores do teste de KAPPA no segundo estágio, denotando que essa melhora foi devido a uma melhor padronização dos examinadores em relação aos critérios de avaliação dos sinais da doença periodontal.

GROSS; GALE ${ }^{38}$, em 1983, fizeram uma avaliação clínica utilizando uma amostra de 1000 pacientes de uma clínica odontológica com o propósito de estudarem a prevalência de sinais comuns de disfunção mandibular, como também de estabelecerem uma metodologia simples, confiável e repetitível na padronização e confiabilidade da palpação muscular. Para tal estudo, foram utilizados 407 homens e 593 mulheres com idade variando de 3 a 89 anos (média 40,5) por um período de 18 meses, escolhidos aleatoriamente. Para testar a habilidade do examinador em aplicar aproximadamente 3 libras de pressão, por 2 segundos, foi usado um algômetro. Todas as palpações foram feitas bilateralmente, exceto para as áreas dos pterigóideos laterais. Foram utilizados o temporal, masséter, pterigóideo lateral, além da face lateral e posterior da ATM e esternocleidomastóideo. Para a palpação foram utilizados os dedos indicadores, médio e anular, num movimento rotatório de um lado a outro, desde a sua origem até a inserção. Todos os 3 dedos eram mantidos em contato com o tecido, alternando a maior pressão de um dedo para outro para maximizar a área de palpação. Duas áreas ósseas (processo mastóide e a orbital) 
foram palpadas bilateralmente com os dedos médios para controle. As respostas dos pacientes à palpação muscular foram classificadas de 0 a 3 : 0 - sem resposta; 1 relato verbal de desconforto; 2 - movimento facial tal como reflexo da pálpebra, associado a relato de dor; 3 - retirada da cabeça em antecipação à palpação, com relato de dor considerável ao contato. Após o término do estudo, a grande maioria das respostas positivas nos músculos/articulação foi moderada/suave, ou seja, 301 de 389 respostas positivas foram 1 na escala de 0 a 3. A palpação da área pterigóidea produziu a mais alta porcentagem de resultados positivos $(14,7 \%)$, seguido da face lateral da ATM (3,9\%), pterigóideo medial (2,5\%), masséter superficial (2,4\%), sendo o restante abaixo de 1\%. Apresentaram desvio de abertura, 17,8\% da amostra, 6,6\% apresentaram distância interincisal abaixo de $37 \mathrm{~mm}$ e $34,7 \%$ tinham sons na articulação. Em relação ao sexo, não foi apresentada diferença em qualquer área testada. Os resultados desse estudo indicaram que a prevalência dos maiores sinais clínicos de disfunção observados numa clínica dentária não é alta.

Em 1983, KOPP; WENNBERG ${ }^{53}$ avaliaram a concordância intra e interexaminadores em um período de 3 horas, na palpação muscular e no movimento mandibular. Para tal objetivo, 19 indivíduos assintomáticos foram examinados aleatoriamente duas vezes, por dois clínicos. Perguntou-se, também, aos indivíduos se eles experimentaram qualquer diferença na pressão durante a palpação entre os dois examinadores. Portanto, 12 dos 19 indivíduos (63\%) consideraram a palpação pelo examinador 1 mais dura do que a do examinador 2 . Os autores concluíram que tanto a concordância intra e interexaminadores foi considerada fraca para os dois itens avaliados.

Em 1985, de acordo com CHAPMAN et al. $^{7}$, houve um progresso considerável na medida da dor nos últimos 25 anos. Após a Segunda Guerra Mundial, os pesquisadores estavam mais preocupados com a avaliação do alívio da dor após a intervenção farmacológica do que com a avaliação da experiência dolorosa humana em si. Além da observação e avaliação do comportamento e expressões dos pacientes, os pesquisadores às vezes necessitam que os pacientes relatem a história de dor durante sua atividade diária normal. Ainda segundo os autores, a dor poderia, 
também, ser medida através de relatos subjetivos da dor, os quais são feitos através da escala de categoria e da escala de análise visual (EAV) utilizadas para medir tanto o alívio da dor após o tratamento, como a dor em si. As escalas de categoria são geralmente utilizadas para avaliar a resposta analgésica; já a EAV conquistou uma popularidade maior que as anteriores em trabalhos clínicos, assim como nos de laboratório. Tais instrumentos são utilizados para medir a dor em diferentes pontos do tempo, por exemplo, "dor no presente momento", "nível de dor durante as últimas 24 horas" ou "dor em sua magnitude máxima".

De acordo com JIMENEZ; LANE ${ }^{46}$, em 1985, um dos problemas encontrados no tratamento dos pacientes com dor crônica é a avaliação da severidade da dor. Para tal objetivo, os autores avaliaram a tolerância de pressão e o limiar de pressão em pacientes com dor crônica. Vinte e um pacientes admitidos consecutivamente em um programa de dor multidisciplinar de janeiro a março de 1985 foram incluídos nesse estudo durante seus 21 dias de internação. Usando um algômetro, as mensurações do limiar e tolerância de pressão foram feitas pelo mesmo examinador no dia de admissão do paciente e em intervalos semanais. Duas leituras foram registradas e expressadas em $\mathrm{Kg} / \mathrm{cm}^{2}$, representando o limiar e a tolerância de pressão. Em 19 dos 21 pacientes, um aumento em ambos os valores foi descoberto sob alta pressão. Leituras em seqüências de acompanhamento foram obtidas um mês após a alta de 12 pacientes, em nove dos quais não foram observadas mudanças. Uma diminuição leve em ambos os valores foi descoberta nos 3 pacientes remanescentes, porém as leituras foram ainda maiores do que na admissão. Portanto, um aumento do limiar de dor à pressão foi proporcional a uma diminuição das reclamações de dor, denotando que as determinações em série do limiar de dor à pressão e da tolerância de pressão são úteis como indicadores da severidade de dor durante tratamentos de pacientes com dor crônica.

A palpação é amplamente aceita como um método para exame dos tecidos moles e duros, intensidade e localização da sensibilidade, grau de tonicidade muscular, pontos de gatilho, inchaço, consistêcia/firmeza e temperatura dos tecidos, de acordo com SOLBERG ${ }^{91}$, em 1986. Segundo este autor, a palpação no 
diagnóstico da dor muscular permanece como um dos exames físicos essenciais, apesar da dificuldade de se reproduzirem os resultados. $O$ autor relata que uma super-interpretação é comum, devido à sensibilidade de algumas estruturas anatômicas, à presença de nódulos inflamados nesta área e, hiperalgia associada à dor referida prolongada. Portanto, o risco de sensibilidade super-relatada sugere que a palpação deva ser usada mais apropriadamente para reiterar observações oriundas de testes funcionais do que como um critério isolado para se detectar a Desordem Temporomandibular. Afirmou-se ainda que a palpação da articulação temporomandibular é mais confiável como um indicador de sensibilidade e inflamação da articulação.

WANMAN; AGERBERG ${ }^{102}$, em 1986, estudaram a prevalência dos sinais da disfunção mandibular em 285 adolescente de 17 anos de idade que viviam na cidade de SKELLEFTEA. Eles foram submetidos a um exame funcional do sistema mastigatório. Os sinais clínicos mais comuns foram a sensibilidade à palpação dos músculos mastigatórios $(41 \%)$ e sons de estalido das articulações temporomandibulares (22\%). A sensibilidade à palpação foi geralmente localizada no músculo pterigóideo lateral e na inserção do tendão temporal. As mulheres foram mais sensíveis à palpação $(p<0.05)$ do que os homens. Os sinais de disfunção clínica foram descobertos em $56 \%$ dos indivíduos e também eram bem mais comuns nas mulheres do que nos homens.

De acordo com VALACHOVIC et al. ${ }^{99}$, em 1986, em investigações a longo prazo, que envolvem um grande número de pacientes, é freqüentemente necessário empregar o uso de múltiplos examinadores, que devem exibir altos níveis de confiabilidade, a fim de se minimizar o desvio/erro sistemático do examinador, o qual pode distorcer as descobertas científicas. Os autores estudaram a confiabilidade de quatro examinadores na avaliação de interpretação de radiografias dentárias. Pelos resultados, o nível de concordância inicial intra-examinadores, através do índice de KAPPA, foi de 0,75 e permaneceu em 0,80 por todo o período de 24 meses do estudo. Esse mesmo índice de concordância interexaminadores entre os seis parelhamentos dos quatro examinadores alcançou de 0,68 a 0,80 para cáries e 0,72 e 
0,83 para doença periodontal. Os resultados, portanto, mostraram que houve uma concordância satisfatória observada interexaminadores e intra-examinadores na interpretação de radiografias.

HUNT $^{40}$, em 1986, fez uma correlação entre três métodos estatísticos - 0 Percentual de Concordância, Correlação de Pearson e o KAPPA - como medidas de confiabilidade inter-examinadores. Segundo o autor, o Percentual de Concordância e a Correlação de Pearson, que são usados freqüentemente para representar confiabilidade inter-examinador, são, muitas vezes, medidas enganosas porque não levam em conta a concordância devido apenas ao acaso. Ainda, medem, também, apenas as associações entre séries de taxas, não levando em conta nenhuma influência sistemática nas taxas. Devido a isso, muitos projetos avaliados por esses dois sistemas chegam a resultados de confiabilidade interexaminadores irreais. Já o método KAPPA é recomendado como uma medida útil para quantificar concordância, além da chance de julgamentos dicotômicos, tais como presença ou falta de doença. O autor conclui que cada método estatístico tem o seu valor, sendo que o pesquisador deve fazer uma escolha criteriosa do mesmo para obtenção de resultados mais próximos da realidade.

Em 1986, FRICTON; SCHIFFMAN ${ }^{27}$ desenvolveram um índice craniomandibular (ICM) cuja finalidade seria a de fornecer uma medida padronizada da gravidade dos problemas no movimento mandibular, barulho da ATM e sensibilidade muscular e da ATM para uso em estudos epidemiológicos e clínicos. Esse índice seria composto pelo índice de disfunção (DI), que engloba itens que refletem os problemas de funcionamento da mandíbula e da articulação, e pelo índice de palpação, que reflete os problemas de sensibilidade muscular e ATM. O ICM seria, portanto, a soma do DI e PI divididos por 2. Para obtenção da confiança desse índice, os autores testaram a confiabilidade de 2 examinadores no exame de 40 pacientes com sintomas de DTM, mantendo em segredo a pontuação obtida pelo índice por cada examinador, obtendo dessa maneira, um coeficiente de correlação intra-classe de 0,84 para o índice de disfunção, 0,87 para o índice de palpação e 0,95 para o ICM, creditando assim, o ICM para uso em estudos clínicos e epidemiológicos. 
Em 1986, JAEGER; REEVES ${ }^{43}$, a fim de determinarem a relação entre a sensibilidade dos pontos de gatilho e os sintomas referidos da dor miofascial, as graduações de intensidade de dor, referidas e medidas pela escala de análise visual e medições pelo algômetro de pressão da sensibilidade dos pontos de gatilho miofasciais, examinaram pacientes antes e depois de tratamento muscular. Vinte indivíduos que possuíam sinais e sintomas de dor miofascial foram escolhidos, dos quais 15 (11 mulheres e 4 homens) tinham dor referida primária unilateral localizada na região cervical, occipital, temporal e frontal, e 5 (3 mulheres e 2 homens) tinham queixas bilaterais. Os autores demonstraram que a sensibilidade dos pontos de gatilho diminuía em resposta ao estiramento passivo quando avaliada pelo algômetro e que diminuições na sensibilidade dos pontos de gatilho local eram acompanhadas por diminuição nos relatos subjetivos de intensidade de dor referida. Além disso, uma análise no grupo de dor unilateral mostrou que os pontos gatilho ativos eram, na verdade, mais sensíveis (tinham limiares de dor menores) do que seus pontos gatilho latente. Subseqüente ao alongamento e ao spray, os pontos de gatilho tornaram-se menos sensíveis do que o controle não estirado (latente). Resultados similares foram encontrados com o grupo que continham pontos de gatilho bilaterais. Portanto, os autores concluiram que o uso do algômetro não está restrito à região da cabeça e pescoço e pode também ser útil na avaliação da sensibilidade de pontos de gatilho em outras partes do corpo.

REEVES; JAEGER; GRAFF-RADFORD ${ }^{83}$, em 1986, investigaram a confiabilidade do algômetro na avaliação da sensibilidade dos pontos de gatilho (pontos de gatilho) em pacientes com dor miofascial da cabeça e pescoço. Para tal pesquisa foram desenvolvidos 3 estudos com o propósito de: 1) testar a confiabilidade intra e interexaminador com o uso do algômetro usando pontos de gatilho previamente marcados; 2) testar, com a mesma finalidade, a confiabilidade interexaminadores em pontos de gatilho não marcados e; 3) verificar se os pontos de gatilho representam uma área discreta dentro do músculo. Para tal estudo, foram utilizados 15 pacientes (11 mulheres e 4 homens, com idade de 24 a 60 anos). O primeiro estudo demonstrou alta confiabilidade nos examinadores, tanto na obtenção do limiar como na localização dos pontos de gatilho. No estudo 2, demonstrou-se confiabilidade 
significante entre os examinadores na localização e medida do limiar, enquanto o estudo 3 levou à conclusão de que os pontos de gatilho são pontos discretos de sensibilidade no músculo. Os autores concluíram que a habilidade de quantificar e medir confiavelmente a sensibilidade dos pontos de gatilho abre as portas para uma gama de possibilidades clínicas e cirúrgicas no que diz respeito a problemas miofasciais e dolorosos músculo-esqueletais relacionados.

KLEINKNECHT et al. ${ }^{51}$, em 1986, examinaram a relação entre o relato de sintomas coletados em uma pesquisa de comunidade com as descobertas num exame clínico, como também as discrepâncias em termos de características psicossociais dos pacientes e a confiabilidade interexaminadores. Para isso, foi feita uma seleção de 65 indivíduos, abrangendo tanto pacientes com sintomas de DTM como assintomáticos. Toda a amostra respondeu a um questionário de sintomas de DTM, onde relataram a presença ou ausência de 14 itens relacionados a tais patologias. Esse questionário também continha várias escalas, com o intuito de avaliar psicologicamente o paciente, além de uma pesquisa de experiência de vida com relato de eventos que os pacientes experimentaram no último ano e que influenciaram suas vidas. Os exames clínicos foram realizados por 4 dentistas que não sabiam da situação clínica e nem das características psico-sociais do paciente. 0 exame incluiu palpação dos músculos da cabeça, pescoço, mastigação e ATM. A palpação foi conduzida, aplicando-se uma pressão digital firme na área examinada, sendo os músculos palpados externamente (temporal, frontal, esternocleidomastóideo, supra e infra-hióide e masséter). O pterigóideo lateral foi palpado intra-oralmente. Os sons da articulação e o movimento de mandíbula também foram avaliados. Treinamento de padronização foi utilizado até que o protocolo estivesse concordante entre os participantes. Os sintomas relatados pelo questionário foram cruzados com o números de sinais de dor descobertos durante 0 exame. Os resultados demonstraram uma relação direta entre o número de sintomas relatados e o número de sinais descobertos durante o exame. Dentre os indivíduos que relataram zero, um ou dois sintomas, $27 \%$ acusaram um sinal durante o exame. Porém quando mais de dois sintomas eram relatados, a porcentagem dos casos com sinais aumentaram. Dentre os 8 indivíduos que relataram todos os sintomas, em 7 
foram descobertos 2 ou mais sinais de dor durante o exame (87,5\%). Os resultados desse estudo indicam que o método do relato do indivíduo ou relato do paciente na identificação de sintomas pode ser de grande utilidade para que os sinais possam ser descobertos durante o exame. Essa relação é particularmente forte para aqueles indivíduos que relatam vários sintomas.

Para avaliarem a reprodutibilidade do teste de palpação para o sistema estomatogmático, DUINKERKE et al. ${ }^{18}$, em 1986, utilizaram dois dentistas experientes e dois estudantes de odontologia, após um programa de treinamento. Foram examinados 58 indivíduos (25 mulheres e 33 homens - idade 18 a 65) assintomáticos. Concluíram que a reproducibilidade intra e interexaminadores para ambos dentistas e estudantes, em relação à palpação dos músculos, foi satisfatória, variando entre 0.73 e 0.95 , como também em relação à abertura bucal.

Em 1986, JENSEN et al. ${ }^{44}$ avaliaram o limiar de dor à pressão (LDP) na região temporal com o uso de um algômetro. Foram realizados 4 estudos. O primeiro estudo utilizou 12 homens e 12 mulheres (24 a 69 anos) e nele o LDP foi determinado na região temporal usando 3 diferentes taxas de aplicação de pressão, com a mesma extremidade do algômetro, tendo este uma área de $0,503 \mathrm{~cm}^{2}$. Em seguida, o LDP foi determinado no lado esquerdo usando 3 diferentes áreas na extremidade, mantendo uma pressão constante. Doze dos 24 indivíduos retornaram para uma segunda aplicação de pressão no lado direito, usando a mesma taxa de pressão, com a área de $0,503 \mathrm{~cm}^{2}$. No estudo 2 uma taxa maior de pressão foi aplicada em ambos os lados. Quatro em 6 mulheres e 4 homens (20 a 29 anos). Quatro diferentes áreas foram usadas. Todos retornaram para 5 repetidos testes com intervalos de 1 semana, sendo que na última semana os pacientes receberam uma aplicação de anestésico em um lado e, no outro, uma aplicação de $9 \mathrm{mg} / \mathrm{ml}$ de solução salina. No estudo 3 , os LDP de 2 mulheres e 4 homens (21 - 36 anos) foram medidos através de 50 tentativas consecutivas, numa força de 0.68 , com uma área de $0,503 \mathrm{~cm}^{2}$. No estudo 4, os LDP de 17 mulheres e 13 homens (19 - 46 anos) foram determinados nos dois lados com a mesma taxa e área anterior. Todos retornaram 45 minutos para uma segunda determinação. Os autores verificaram que no estudo 1 houve uma 
diminuição do LDP quando a área foi aumentada e que, usando uma mesma área na extremidade do algômetro, com aplicação de 3 cargas diferentes, houve um aumento do LDP com a taxa aumentada. Houve, também, uma correlação positiva entre os LDP em ambos os lados. No estudo 2 não houve diferenças no LDP nas 4 áreas analisadas. Houve um gradual aumento do LDP nas diversas investigações realizadas. Não houve diferenças do LDP após a injeção do anestésico e da solução salina nos dois lados, mas ambos LDP aumentaram significativamente. No estudo 3 não houve alterações do LDP após 50 medições consecutivas. No estudo 4 não houve diferença significante entre os 2 lados, entre o primeiro e o segundo exame. Também não houve uma correlação significante em relação ao sexo e idade na obtenção do LDP.

Em 1987, ROBERTS et al. ${ }^{85}$ compararam os achados artrográficos com a sensibilidade à palpação dos músculos da mastigação. Segundo os autores, a sensibilidade à palpação muscular tem sido freqüentemente usada como um parâmetro clínico de disfunção mandibular relacionado ao desarranjo interno. Para tal estudo, 205 pacientes com sinais e sintomas de DTM foram examinados pela artrografia, com 222 articulações (188 unilaterais e 17 bilaterais) sendo examinadas. Os artrogramas foram classificados em pacientes normais, com deslocamento e sem deslocamento. Como parte do exame, os músculos da mastigação, da cabeça e pescoço foram palpados bilateralmente. Descobertas significativas foram encontradas na porção média do músculo temporal em pacientes "normais" (20\%), quando comparados com pacientes apresentando deslocamentos de disco com (10\%) e sem (5\%) redução. O músculo masséter superficial foi mais sensível em pacientes "normais" (27\%) e em pacientes "com redução do disco" (27\%) do que em pacientes "sem redução do disco" (17\%). O músculo pterigóideo medial foi mais sensível em pacientes "normais" (24\%) e pacientes "sem redução" (16\%) do que "com redução" (8\%). As respostas à palpação do tendão temporal não foram bem diferentes nos 3 grupos., sendo o mesmo mais sensível de todos. Os autores, portanto, sugerem que a sensibilidade muscular sozinha não é um indicador específico para a presença de desarranjos internos. 
LIST; HELKIMO ${ }^{60}$, em 1987, avaliaram a confiabilidade da medida do limiar da pressão no registro da sensibilidade no músculo masséter. Para tal propósito, quinze indivíduos (14 mulheres e um homem) com uma média de idade de 35 anos, foram incluídos neste estudo. Um algômetro foi usado para registrar o grau de sensibilidade muscular e dois examinadores registraram independentemente cinco pontos bem definidos, previamente marcados na pele sobre o músculo masséter. De acordo com os autores, o desvio máximo para uma mensuração repetida foi menor que $4 \mathrm{~mm}$, indicando que foi possível localizar os pontos de mensuração com boa precisão em registros repetidos. Os registros repetidos do grau de sensibilidade muscular com a ajuda do algômetro mostraram altas correlações em comparações intra e inter-indivíduos. Os valores médios das mensurações do limiar da dor em diferentes pontos de mensuração variaram entre $1.95 \mathrm{~kg} / \mathrm{cm}^{2}$ (a origem do músculo masséter superficial) e $2.95 \mathrm{~kg} / \mathrm{cm}^{2}$ (a porção profunda do músculo masséter). O estudo mostrou que a sensibilidade no músculo masséter pode ser registrada com boa precisão com a ajuda de um algômetro.

De acordo com TRUELOVE et al. ${ }^{97}$, em 1987, os sons da articulação temporomandibular têm sido freqüentemente relatados como sendo associados à patologia da articulação. Poucas pesquisas foram publicadas mostrando a confiabilidade dos examinadores na classificação e consistência dos sons da articulação com o passar do tempo. Para tal estudo, portanto, os autores avaliaram os sons produzidos na articulação em cinco pacientes e cinco indivíduos como grupo controle, utilizando pares de examinadores com estetoscópios. Os examinadores registraram todos os sons que estavam presentes e não tinham acesso visual às observações do parceiro. A confiabilidade dos examinadores às mudanças nos sons da articulação, após oito exames, durante um período de 90 minutos, foram examinadas. Os pares de examinadores concordaram na avaliação dos sons em 136 dos 211 julgamentos, obtendo um valor do teste de KAPPA (K) médio de 0.58. A análise da variação dos sons nas 16 articulações revelou que os sons alteraram-se após um tempo em 12 das 16 articulações. Os examinadores concordaram que os sons não estavam presentes em 39 das 136 (29\%) observações realizadas. Os sons mais freqüentes foram estalidos, seguidos da crepitação leve. Portanto, a 
confiabilidade dos examinadores foi considerada aceitável. Contudo, a natureza altamente variável dos sons exige que uma cautela seja usada na interpretação dos mesmos no diagnóstico e tratamento das Desordens Temporomandibulares.

Em 1987, ERIKSSON; WESTESSON; SJOBERG ${ }^{23}$ avaliaram 0 desempenho inter e intra-examinadores na auscultação de sons na ATM. Para tal estudo, 22 examinadores (11 estudantes de Odontologia e 11 professores da Faculdade) foram utilizados. Os sons eram obtidos através de estestocópio, que era ligado a um microfone, e gravados posteriormente. Os sons da ATM foram registrados durante 5 seqüências de abertura e fechamento sem os dentes se fecharem completamente. Esse estudo mostrou uma alta concordância intraexaminadores com uma média de $79 \%$ contra uma baixa concordância (14\%) verificada na análise interexaminadores. Os autores concluíram que as opiniões divergentes sobre as características dos sons (estalido, crepitação) indicam que estes sinais clínicos não são tão objetivos como postulado anteriormente, e que a auscultação, em conjunto com a palpação, é uma maneira de melhorar o desempenho dos examinadores no registro dos sons da ATM.

Em 1987, FISHER ${ }^{24}$ estudou o limiar de dor a pressão exercida com o uso do algômetro (LDP) em 24 homens e 21 mulheres que, freqüentemente estavam afetados pelos os pontos de gatilho. Primeiramente, os pontos de gatilho foram detectados pela palpação usando os dedos. Após a detecção da área afetada, o algômetro era utilizado. Após a infiltração de anestésico nos os pontos de gatilho, nova medição foi feita com o uso do algômetro, verificando-se, assim, um aumento no LDP de $4 \mathrm{~kg} / \mathrm{cm}^{2}$, em média. Portanto, o autor correlacionou significantemente o LDP com as mudanças do estado clínico dos pacientes, concluindo que o algômetro pode ser usado para monitorar a sensibilidade e inflamação.

Testar a validade de um índice para a medição das Desordens Craniomandibulares foi o propósito de FRICTON; SCHIFFMAN ${ }^{28}$, em 1987. De acordo com os autores, esse índice, para ser considerado válido, teria que conter itens representativos do problema estudado; apresentar escalas que comprovassem a eficácia do tratamento proposto, assim como poder ser comparado a outros índices na 
medição do mesmo problema. Todas essas especificações foram incluídas nesse índice, aprovando-o em estudos de efeitos clínicos. Portanto, o índice (ICM) parece ser válido para estudos clínicos, no entanto, os usuários devem estar cientes de seus erros e suas diretrizes metodológicas estritamente associadas a garantir a exatidão e reprodutibilidade dos resultados. Se estudos com múltiplos examinadores são usados, é recomendado que os mesmos discutam todos os itens antes de começarem o estudo, e usem um algômetro de pressão para palpação do músculo.

Em 1987, THOMAS; OKESON ${ }^{96}$ avaliaram os sintomas do músculo pterigóideo lateral utilizando duas técnicas diferentes de exame. Para tal objetivo foram utilizados 49 estudantes de odontologia como controle (33 homens e 16 mulheres) e 59 pacientes apresentando sinais e sintomas de patologia muscular. Ambos os grupos foram avaliados com palpação digital e manipulação funcional. No grupo controle, $14,3 \%$ dos indivíduos afirmavam ter algum tipo de desconforto mastigatório (85,7\% eram mulheres). Nesse grupo, nenhum músculo pterigóideo lateral foi sintomático à manipulação funcional, enquanto $27,6 \%$ dos mesmos músculos foram sintomáticos à palpação digital. No grupo sintomático, todos os indivíduos apresentavam dor mastigatória como um componente de sua disfunção, $69,5 \%$ dos músculos foram sintomáticos à palpação digital, diferentemente dos 27,1\% que apresentavam sensibilidade à manipulação funcional. Esses resultados sugerem que a palpação do músculo pterigóideo lateral não é um método efetivo de determinação da sintomatologia desse músculo.

Segundo OKESSON ${ }^{79}$, em 1988, a palpação do músculo é realizada principalmente pela superfície palmar do dedo médio, com o dedo indicador testando as áreas adjacentes. Uma pressão única, firme, de 1 ou 2 segundos de duração é, em geral, melhor do que várias pressões leves. O grau de desconforto é importante no reconhecimento do problema do paciente, assim como pode ser um método excelente para avaliar os efeitos do tratamento. Uma tentativa deve ser feita, portanto, não apenas para identificar os músculos afetados, mas também para classificar o grau de dor em cada músculo. A dor ou sensibilidade de cada músculo é registrada em uma ficha de exame, que ajudará no diagnóstico e será posteriormente 
usado na avaliação do progresso do tratamento. Um exame neuromuscular minuncioso deveria identificar não só o desconforto e dor generalizada do músculo, mas também identificar pequenas áreas hipersensitivas nos músculos chamados de pontos gatilho, que atuam como fonte de estímulo doloroso profundo, podendo produzir efeitos excitatórios centrais. Para localizar os pontos-álgicos, o examinador palpa a extensão inteira de cada músculo.

SHIFFMAN et al. ${ }^{86}$, em 1988, compararam os LDPs de 15 locais da cabeça e pescoço em 45 pacientes que tinham "síndrome de dor miofascial" com aqueles dos 45 controles combinados por idade e sexo. Esse estudo foi planejado para comparar a confiabilidade do uso do algômetro e da palpação muscular manual e para examinar a confiabilidade interexaminadores em ambas as técnicas. Os resultados obtidos pela palpação manual foram realizados através de respostas verbais do paciente para a seguinte questão: "isto dói ou apenas pressiona?". Uma resposta positiva indicava que a palpação feita era dolorida e uma resposta negativa indicava apenas pressão. O LDP foi registrado e repetido em 5 segundos para obter a média para cada um dos 15 locais palpados. O teste de KAPPA, usado para avaliar a confiabilidade entre dois examinadores, com o algômetro demonstrou valores maiores que 0,40 em 13 dos 15 locais, com a exceção dos músculos masséter profundo e temporal posterior. Para a palpação manual, somente 2 dos 15 locais (o temporal anterior e esternocleidomastóideo) alcançaram este nível de confiabilidade. Os autores concluíram que a confiabilidade do algômetro é adequada e superior ao uso da palpação manual. Eles também observaram que a confiabilidade adequada da palpação manual pode ser possível para locais específicos com examinadores experientes e técnicas padronizadas.

Investigar a confiabilidade interexaminadores e a do teste-reteste em dez pacientes com fibromialgia crônica foi o propósito de TUNKS et al. ${ }^{98}$, em 1988. Esse estudo empregou um algômetro desenhado para reproduzir a palpação com o polegar, usando uma pressão firme, constante, de $1 \mathrm{~kg}$. A ausência de quaisquer efeitos significativos de tempo ou examinadores, assim como o cálculo dos coeficientes de generalidade levou os autores a concluírem que um alto grau de 
confiabilidade interexaminadores $(0,85)$ e teste-reteste $(0,85)$ poderia ser alcançado pelo uso de seus métodos utilizando o algômetro em pacientes com fibromialgia crônica.

Esses mesmos autores ${ }^{98}$, ainda em 1988, estabeleceram a confiabilidade interexaminadores e do teste-reteste com o uso de um algômetro de pressão em 5 homens e 5 mulheres que sofriam de fibromialgia crônica, e um grupo normal de 5 homens e 5 mulheres. Todos foram examinados 2 vezes por cada um dos 2 examinadores independentes, usando uma pressão de $1 \mathrm{~kg} / \mathrm{s}$ sobre "10 pontos sensíveis" parelhados, localizados por marcadores na pele. Obtiveram-se limiares de sensibilidade bem mais baixos nos pontos sensíveis na fibromialgia comparados aos indivíduos normais, com testes estatísticos mostrando uma alta confiabilidade interexaminador $(0,85)$ e no teste-reteste $(0,85)$. Foram descobertas diferenças altamente significativas entre os pontos sensíveis específicos. Dez indivíduos normais e dez indivíduos com fibromialgia foram novamente examinados em 5 pontos sensíveis e 5 pontos não sensíveis e outra vez houve uma grande diferença nos valores dos LDP.

LE RESCHE; BURGESS; DWORKIN ${ }^{57}$, em 1988, analisaram a confiabilidade da escala de análise visual e da escala descritiva verbal na medição da dor em pacientes com Desordens Temporomandibulares. Para isso, utilizaram 8 dentistas que assistiram a videotapes padronizados mostrando a palpação da ATM e dos músculos mastigatórios, os quais fizeram seus julgamentos concernentes à quantidade de dor que os pacientes estavam experimentando. Esses julgamentos foram registrados usando uma escala descritora verbal de 4 pontos (VDS) contendo a nomenclatura dor "nenhuma", "suave", "moderada" e "severa" e uma escala de análise visual de 100mm (EAV) ancorada nos termos "sem dor" e "pior dor possível". Cada avaliador participou de 2 sessões, separadas por uma semana. Em cada sessão foi utilizada 1 escala. Houve uma boa confiabilidade obtida intra-examinadores, mas houve uma grande variabilidade interexaminadores. Portanto, de acordo com os resultados, os autores concluíram que nem a escala VDS, nem a EAV contituem uma ferramenta altamente confiável para a quantificação da dor na palpação da DTM. 
Nesse mesmo ano, DWORKIN; LE RESCHE; DE ROUEN ${ }^{20}$ avaliaram a confiabilidade interexaminadores na mensuração clínica das Desordens Temporomandibulares. Para tal objetivo analisaram, primeiramente, 48 pacientes, 18 com sintomas de DTM e 30 assintomáticos, apresentando a mesma idade e distribuídos igualmente em relação ao sexo. Quatro examinadores treinados (higienistas dentais) e três sem treinamento (dentistas especialistas em DTM), examinaram cada paciente. Com relação aos resultados obtidos das medições interarcos (overbite, overjet) e abertura mandibular, o coeficiente de correlação intraclasse mostrou uma média total de 0.91 para os examinadores treinados e 0.84 para os não treinados. Por esses resultados, evidenciou-se que os examinadores treinados são mais confiáveis. Com relação à classificação de oclusão (Angle) e padrão de abertura mandibular, os valores iniciais de KAPPA foram respectivamente 0.40 e 0.42 para os examinadores treinados, e 0.37 e 0.30 para os não treinados. Após um treinamento adicional, os examinadores treinados passaram de 0.40 para 0.78 e de 0.42 para 0.70 na classificação de oclusão e padrão de abertura mandibular, respectivamente. Com relação à palpação dos músculos extra-orais, intra-orais e ATM, os valores iniciais de KAPPA foram $0.47,0.27$ e 0.47 para os examinadores treinados e $0.39,0.13$ e 0.25 para os não treinados, respectivamente. Após um treinamento adicional, os examinadores treinados passaram de 0.47 para 0.65 , de 0.27 para 0.61 e de 0.47 para 0.52 respectivamente. Para essa palpação, os examinadores foram calibrados para exercer 2 libras de pressão digital nos músculos extra-orais e 1 libra nos músculos intra-orais. Os pacientes responderam classificando sua dor numa escala de 0 a 3. Com relação à confiabilidade dos sons da ATM, os valores iniciais de KAPPA com o uso da palpação e do estestocópio foram 0.39 e 0.25 para os examinadores treinados e 0.30 e 0.35 para os examinadores não treinados, respectivamente. Após um treinamento adicional, os examinadores treinados passaram de 0.39 para 0.62 e de 0.25 para 0.61 . Os autores verificaram que as respostas de dor à palpação mudaram após o curso do exame de confiabilidade e que poderiam, pelo menos, explicar parcialmente a baixa concordância dos interexaminadores. Portanto, os autores concluíram que o treino dos examinadores é extremamente importante para uma avaliação confiável dos sinais das DTM. 
Em 1989, STOCKSTILL; GROSS; MCCALL ${ }^{92}$, avaliaram 104 indivíduos que participavam de um projeto de pesquisa, dos quais 45 atendiam aos critérios de seleção que incluíam dor palpável em dois ou mais músculos da mastigação e com história de dor de, no mínimo, 6 meses de duração. A intenção desse estudo foi determinar: 1) se dois investigadores poderiam obter um grau aceitável de confiabilidade durante a palpação dos músculos e ATM; 2) se o grau de confiabilidade pode ser aumentado por posterior padronização e 3) se a confiabilidade obtida pode ser mantida por um certo período de tempo (5 semanas). A seqüência dos eventos para a palpação foi a seguinte: os dois examinadores padronizaram um ao outro; o primeiro exame do paciente foi conduzido na mesma semana, com uma padronização posterior sendo realizada nesse mesmo momento. O segundo exame dos pacientes foi conduzido uma semana após a primeira, e um terceiro exame foi conduzido 5 semanas após o $2^{\circ}$ exame sem padronização adicional. Três libras de pressão foram usadas para a palpação e um score de "0 a 3" foi usado para avaliar o relato do paciente em relação à sensibilidade, onde "0" era considerado sem dor, "1" relato de desconforto, "2" quando havia um movimento facial e "3" correspondia a um movimento para o lado oposto antes da palpação. As seguintes áreas foram palpadas bilateralmente: aspecto lateral da ATM, o meato auditivo externo, músculo temporal (anterior, médio e posterior), masséter (origem e inserção) pterigóideo médio, esternocleidomastóideo, trapézio e pterigóideo lateral. Quatro testes estatísticos foram empregados nesse estudo: porcentagem de concordância, coeficiente de correlação de Spearman, o teste de Mann - Whitney e o teste de Kappa, este estabelecendo limites de concordância: 0,00 - 0,20 (leve); 0,21 - 0,40 (regular); 0,41 - 0,60 (moderado); 0,61 - 0,80 (satisfatório) e; 0,81 - 1,00 (quase perfeito). Obtevese, assim, um valor de Kappa de 0,37 no primeiro exame, indicando uma concordância regular entre os dois examinadores, aumentando para 0,70 no exame 2 e para 0,63 no exame 3, ambos indicando uma concordância satisfatória. Os resultados indicaram, portanto, que dois examinadores podem obter um grau aceitável de confiabilidade quando padronizado cuidadosamente. Uma padronização posterior pode resultar em uma maior confiabilidade, e a confiabilidade pode ser mantida por 
um período mínimo de 5 semanas, onde o reforço na padronização parece ainda ser mantido.

A confiabilidade e validade do uso do algômetro no registro de sensibilidade no músculo masséter e temporal anterior foram avaliadas por LIST; HELKIMO; FALK ${ }^{61}$, em 1989. Para tal estudo utilizaram 45 indivíduos (40 mulheres e 5 homens), sendo 25 voluntários saudáveis e 20 pacientes sintomáticos. Nesse estudo, 2 tipos de algômetro foram utilizados. A sensibilidade à palpação foi medida em 6 pontos localizados no músculo masséter, temporal anterior e sobre o arco zigomático para avaliar: (parte 1) - a validade do LDP por comparação com a técnica de palpação convencional, limite de dor de pressão nos indivíduos sintomáticos e assintomáticos; (parte 2) - a reprodutibilidade do algômetro por medições repetidas do limite de dor de pressão em 6 pontos definidos, observando se os valores do algômetro alteram significativamente com o erro de localização; (parte 3) - se a razão de aplicação de pressão pelo algômetro afetou o limite de dor e pressão. $\mathrm{Na} 1^{\underline{a}}$ parte, os registros foram feitos por 3 examinadores independentes com o algômetro, com uma força de $1 \mathrm{~kg} / \mathrm{cm}^{2}$, e por outro, que palpou manualmente os 6 pontos marcados, sendo o registro feito por relato do paciente: 0 (sem sensibilidade); 1 (sentimento de dor forte) e 2 (reflexo palpebral ou um sinal de pulo). Na parte 2, os 6 pontos eram marcados pelo examinador 1 sobre a pele e transferidos para análise, depois apagados e repetidos pelo examinador 2 . Na parte 3 foram utilizados 2 algômetros: um aplicando uma pressão de $1 \mathrm{~kg} / \mathrm{cm}^{2}$ e o outro $2 \mathrm{~kg} / \mathrm{cm}^{2}$. Pelos resultados, os autores verificaram que houve uma correlação estatisticamente significante entre a técnica com o algômetro e a palpação com os dedos e que uma diferença estatisticamente significante do limiar de dor à pressão foi obtida para o grupo sintomático e o grupo assintomático. Houve ótima confiabilidade na localização dos locais marcados, sendo que os autores afirmaram ainda que se os pontos forem localizados com uma certa imprecisão, os coeficientes de confiabilidade seriam ainda da mesma grandeza. Portanto, o uso do algômetro pode ser recomendado para a avaliação dos limites de dor de pressão no sistema mastigatório em estudos clínicos e experimentais. 
A habilidade de dentistas em detectar problemas psicológicos através de exame clínico foi avaliada por OAKLEY et al. ${ }^{75}$, em 1989. Para tal objetivo, 107 pacientes com DTM foram submetidos, primeiramente, a testes psicológicos, e depois submetidos a exames conduzidos pelos dentistas, através do uso de uma escala onde eram solicitados a indicar a presença ou ausência de depressão, ansiedade e estresse. Os resultados dos testes psicológicos permaneciam desconhecidos para os dentistas. Os autores concluíram que um procedimento de exame baseado nas impressões do dentista em um exame inicial não identificam adequadamente os problemas psicológicos de pacientes com DTM.

De acordo com GALLAGHER; DAL SANTO; RUGH ${ }^{30}$, em 1989, o algômetro de pressão tem sido usado para determinar o limiar de dor à pressão em situações clínicas, método esse considerado subjetivo na determinação do limiar de dor. De acordo com os autores, se a dor é detectada pela palpação, o algômetro pode ser aplicado na área para medir a quantidade da força capaz de causar dor, ou seja, o algômetro é colocado no ponto mais sensível e a pressão é lentamente aumentada até os sinais do paciente anunciarem qualquer alteração de dor. Nesse momento, o examinador olhará para o mostrador indicando, assim, a pressão que leva o paciente a sentir dor. Essa alteração no limiar ou tolerância poderá ser registrada e comparada em futuras visitas.

OHRBACH; GALE ${ }^{78}$, em 1989, testaram 4 hipóteses num trabalho de confiabilidade e validade em pacientes com dor miogênica: $1^{\circ}$ ) existe confiabilidade e validade do limiar de dor à pressão (LDP) em pacientes sintomáticos e assintomáticos; $2^{\circ}$ ) as medidas do LDP entre testes e entre sessões são confiáveis; $\left.3^{\circ}\right)$ o LDP nos locais que produzem dor local são menores do que aqueles que produzem dor referida; $4^{\circ}$ ) a qualidade do local seria relacionado ao relatório da palpação e o examinador seria confiável em sua avaliação. Para responder a essas questões foram selecionados 45 indivíduos com idade de 17 a 77, média de 38,6 (89\% eram mulheres) com queixas de DTM. Os exames foram feitos em 2 etapas. $\mathrm{Na} 1^{\text {a }}$ etapa, utilizando-se o grupo sintomático foi feito um relato dos sintomas e a aplicação da escala de análise visual (EAV). A palpação dos músculos foi realizada 
para selecionar os locais de medição do LDP (doloridos) utilizando uma pressão consistente de 1,47 a 1,68kg por 4-5 segundos, com o dedo indicador. Os autores, portanto, concluíram que o $1^{\circ}$ estudo demonstrou forte validade na medida do LDP entre sintomáticos e assintomáticos; o LDP não foi significantemente diferente entre o local de dor primária e o local de controle sem dor no mesmo músculo; o LDP foi bem menor no local de dor comparado ao local de controle sem dor; o segundo estudo indicou uma confiabilidade adequada na obtenção do LDP; no terceiro estudo o LDP foi bem menor em locais que produziam dor referida do que nos locais que produziam dores localizadas pela palpação; o quarto estudo apresentou evidências de que áreas de nódulos e feixes palpáveis foram comumente associados a regiões musculares que produziam dor. Além do mais, a confiabilidade intra-examinador na reavaliação desses locais foi apenas razoável. A dor referida teve uma pobre associação com a dor padrão e achados físicos.

Em 1989, LANGEMARK et al. ${ }^{55}$ compararam os limiares nociceptivos a estímulos mecânicos e térmicos em pacientes com cefaléia crônica tensional. Foi feita palpação da região pericraniana em 50 pacientes com história de dor de cabeça e um valor total de sensibilidade foi calculado. As palpações foram executadas inicialmente e repetidas 2 a 4 semanas depois pelo mesmo examinador. Após a localização do local mais dolorido nas regiões do temporal e occipital, o limiar de dor à pressão (LDP) era medido com o algômetro. Em 32 desses pacientes os limiares de dor ao calor e frio foram medidos. Vinte e quatro indivíduos saudáveis serviram como grupo controle. Quando o resultado da palpação manual obtido no primeiro exame foi comparado com o resultado do segundo, houve uma grande diferença na obtenção dos resultados. Uma correlação positiva entre o resultado da sensibilidade total obtida com a palpação manual e o relato de dor de cabeça na hora do exame foi somente estatisticamente significante na segunda visita. Não houve uma correlação entre os limiares obtidos na região do masséter e temporal com a presença de dor de cabeça. Os LDP obtidos na região temporal foram mais baixos do que os da região occipital. Houve, também, uma correlação positiva do LDP na região do temporal com o LDP da região do occiptal e uma correlação negativa na obtenção do LDP com a sensibilidade obtida pela palpação manual. 
Ainda em 1989, OHRBACH; GALE $^{77}$ utilizaram o algômetro para verificar o limiar de dor à pressão (LDP) em músculos normais verificando sua confiabilidade, efeitos da medição e diferenças topográficas. Para tal objetivo, foram utilizados 5 homens e 5 mulheres assintomáticos. Os músculos masséter e o temporal anterior foram selecionados quanto à medição por causa do freqüente envolvimento dos mesmos em Desordens Temporomanibulares, acessibilidade, planificação e apoio uniforme pelo tecido subjacente. Para localizar com precisão os locais dos músculos a serem palpados foi utilizado um molde de plástico. Isso era sempre feito 10 minutos antes do procedimento de palpação, período em que os indivíduos recebiam todas as instruções para a pesquisa. O limiar de dor à pressão (LDP) foi definido como aquele ponto em que uma força lentamente crescente aplicada sobre a pele do indivíduo (pelo algômetro) mudava de sensação de pressão para dor. Foram realizados 2 estudos: o primeiro, com intervalos de 3 segundos entre os locais e de $4-5 \mathrm{~min}$ entre os 5 testes realizados; no segundo, as medidas foram feitas em intervalos semanais de 4 semanas e a 5 sessão em 8 semanas. Considerando os testes estatísticos, houve um aumento do LDP em alguns locais, diminuição ou manutenção de niveis iniciais em outros. A interpretação das informações pelos testes estatísticos indicou que o LDP foi significantemente maior no músculo temporal que no masséter, obtendo-se um índice de confiabilidade que variou de 0,55 a 0,93. Os LDP obtidos através de múltiplas sessões foram confiáveis e sem diferenças. Ainda, de acordo com os autores, mais que 3 testes para a obtenção do LDP não são justificados, considerando uma redução crescente em erro contra o aumento do tempo. Concluiuse, então, que uma média de 2 testes seria ideal para a tomada do LDP.

Com o propósito de verificar quais aspectos de um exame clínico seriam mais confiáveis, GOULET; CLARK ${ }^{31}$, em 1990, recrutaram 35 indivíduos (todos mulheres), sendo 19 pacientes com DTM e 16 do grupo controle, sem sintomatologia. Exames repetidos foram realizados seqüencialmente por pares de examinadores aleatoriamente selecionados entre um grupo de nove clínicos experientes. Todos os exames foram feitos com os examinadores sem conhecerem a situação clínica dos indivíduos (pacientes ou não). Os examinadores foram familiarizados com o protocolo e treinados para aplicar uma pressão de 1.3 e $1.8 \mathrm{Kg} / \mathrm{cm}^{2}$ nos músculos masséter 
superficial, temporal médio, aspecto lateral e posterior da ATM. A quantidade de sensibilidade à palpação e dor sob pressão com um algômetro foi determinada por meio de relato do paciente como sem dor, dor suave, moderada ou severa. Para avaliar a confiabilidade da sensibilidade muscular, tanto a padronização da pressão manual por 2 segundos, como a determinação do limiar de dor à pressão, usando um algômetro foram usados. Os resultados indicaram uma razão de concordância total entre os examinadores na presença ou ausência de sensibilidade muscular. Além disso, a avaliação dos valores dos limiares de dor à pressão permitiu aos examinadores distinguir pacientes de não pacientes a uma razão de probabilidade muito alta. Com isso em mente, os clínicos poderiam alcançar uma boa distinção entre pacientes e não pacientes e entre pacientes com dor muscular e sem dor muscular. Além disso, os autores verificaram que a análise do movimento mandibular é altamente reproduzível entre examinadores. Além de usar os movimentos como um meio de detectar um subgrupo de pacientes de DTM que têm hipomobilidade, também pode ser utilizada para diferenciar pacientes de não pacientes, ou seja, verificou-se que a proporção de pacientes com DTM com mais de $45 \mathrm{~mm}$ (incluindo o trespasse vertical) de abertura sem dor é razoavelmente baixa, quando comparada aos não pacientes. A probabilidade de um paciente com DTM ter uma abertura máxima sem dor de menos de 45mm é estimada em 3:1. Além disso, a presença de sons da articulação pôde ser detectada com a informação dos pacientes, usando inspeção manual na articulação durante o movimento mandibular numa confiabilidade entre os examinadores de $90 \%$.

A confiabilidade dos examinadores clínicos na avaliação dos sinais clínicos de DTM como movimento de mandíbula, som na articulação, dor pela palpação muscular e ATM e classificação da oclusão foram avaliados por DWORKIN et al. ${ }^{21}$, em 1990. Para tal estudo foram selecionados 64 voluntários, assintomáticos e normais, representando uma variedade de desarmonias oclusivas e pacientes com dor e sintomas relativos à DTM da Clínica de Disfunção, ambos da Universidade de Washington. A maioria da amostra era composta por mulheres entre 20 e 40 anos, $60 \%$ composto por pacientes sintomáticos e $40 \%$ assintomáticos. Para esse estudo foram recrutados 4 especialistas em higiene dental e três clínicos experientes em 
DTM. Os especialistas em higiene dental submeteram-se a 40 horas de treinamento e calibração antes de conduzirem os exames com pacientes e controles. Os dentistas, que eram especialistas em DTM, não se submeteram a treinamento similar. Vinte e quatro voluntários foram avaliados pelos 4 higienistas e dois dentistas especialistas, em variáveis denominadas como "fixas", pois se presumia que testes repetidos não influenciariam nos dados clínicos. Essas variáveis incluíam a classificação da oclusão e avaliação do trespasse vertical e horizontal. Para um outro grupo de 24 voluntários, a avaliação foi feita por 4 higienistas e 3 especialistas, usando um protocolo similar para as variáveis "flutuantes" (palpação muscular e a ATM e identificação dos sons articulares). Finalmente, um terceiro grupo de 16 voluntários foi avaliado por 4 higienistas após nova calibração e treinamento. Esse estudo avaliou estatisticamente os efeitos para as denominadas variáveis fixas e flutuantes através de 2 métodos estatísticos: o coeficiente de correlação intraclasse (ICC) e o teste de KAPPA (K), onde o limite de 0,4 a 0,6 era considerado uma confiabilidade moderada e os valores de $\mathrm{K}$ acima de 0,6, uma confiabilidade mais aceitável. Foi encontrada excelente confiabilidade para medição do movimento vertical, mas não para movimentos excursivos e protrusivos. No entanto, muitos sinais clínicos importantes no diagnóstico diferencial dos subtipos de DTM não foram medidos com alta confiabilidade. Em particular, a avaliação da dor em resposta à palpação muscular e da ATM e a identificação dos sons da ATM apresentaram uma confiabilidade modesta. Não houve também uma confiabilidade satisfatória em relação à classificação da oclusão. Apesar da obtenção de uma confiabilidade modesta à aceitável, o grupo de higienistas (padronizado) apresentou sempre um nível maior de confiabilidade. Portanto, os achados sugerem que clínicos experientes mostraram baixa confiabilidade, corroborando a importância do estabelecimento padrões clínicos confiáveis para o exame e a classificação diagnóstica das DTM.

De acordo com WIDMER et al. ${ }^{105}$, em 1990, a sensibilidade de um teste é calculada pela divisão do número de casos com doença pelo número total de pacientes que são conhecidos por terem a doença. A especificidade é calculada pela divisão do número de pessoas corretamente identificadas pelo novo teste como isentas da doença pelo número total em uma amostra assintomática. O nível de 
sensibilidade e especificidade do diagnóstico considerado aceitável para um teste depende da prevalência e gravidade da doença e da estimativa de erros devido ao mau diagnóstico. Visto que entre 4 e $7 \%$ da população geral procura tratamento para a TMD, e porque a vida do paciente não está em risco por causa da TMD, baixos níveis de sensibilidade (positiva verdadeira) podem ser usados para esta desordem. Em outras palavras, por causa da baixa ocorrência na população e zero de mortalidade, alguém pode aceitar baixos níveis de sensibilidade para detectar os pacientes com TMD, isto é, alguém pode arriscar usando um teste que classifica alguém que tem doença como um assintomático. Por outro lado, o paciente assintomático que é incorretamente diagnosticado como tendo a desordem pode incorrer em custos financeiros e humanos substanciais, e poderia estar sujeito a um tratamento desnecessário e potencialmente danoso. Portanto, a especificidade exigida para um novo método de diagnóstico da TMD deve ser muito alta. Pelas razões dadas acima, o autor considera 0,75 como um nível mínimo aceitável para sensibilidade e 0,90 para especificidade. Isso permite que um teste a ser usado diagnostique mal $25 \%$ daqueles com desordens como normais e aceite $10 \%$ de normais mal diagnosticados como pacientes com TMD. Isso está dentro da amplitude/alcance de muitos testes diagnósticos médicos atuais.

De acordo com MOHL et al. ${ }^{72}$, em 1990, o principal critério de avaliação do mérito científico de uma publicação de artigo clínico é a confiabilidade e validade. Portanto, para que o estudo possa ser repetido, ele precisa ter seus objetivos e medidas descritas claramente. Essas medidas precisam ser repetidas em um número suficiente de pacientes e em indivíduos normais para avaliar a variabilidade inerente do sujeito humano. O estudo deveria ser repetido em outro laboratório ou clínica para mostrar que o fenômeno não é peculiar a um operador ou um ambiente. Segundo os autores, os componentes para testar validade são hipóteses testadas, medidas objetivas e apropriados grupos controle.

De acordo com MCNEILL ${ }^{67}$, em 1990, as Desordens Temporomandibulares representam um termo coletivo compreendendo um número de problemas clínicos que envolvem a musculatura e/ou a articulação temporomandibular. Embora, 
tradicionalmente, elas tenham sido vistas como uma síndrome, pesquisas atuais apóiam a idéia de que DTM é um conjunto de desordens relacionadas ao sistema mastigatório com muitas características comuns. O sinal mais comum é a dor, normalmente localizada nos músculos da mastigação, na área pré-auricular, ou na articulação temporomandibular, ou ambos. Os sintomas comuns incluem dor mandibular, dor de ouvido, dor de cabeça e dor facial. Além das queixas de dor, os pacientes com essas desordens freqüentemente têm o movimento mandibular limitado e sons na articulação, normalmente descritos como estalido, crepitação. Os sinais e sintomas de DTM podem ser transitórios e auto-limitantes, resolvendo-se sem efeitos sérios a longo prazo. Além disso, pouco se conhece sobre quais sintomas e sinais irão progredir para condições mais sérias. O autor afirma, ainda, que a maioria das DTM parece ser suave e auto-limitante. Contudo, um certo número de pacientes com DTM desenvolvem uma síndrome de dor crônica. Embora uma grande porcentagem da população tenha sinais e/ou sintomas, estima-se que somente cerca de $5 \%$ estejam necessitando de tratamento.

GOULET; CLARK; FLACK ${ }^{32}$, em 1991, verificaram a alternância dos sintomas pelos indivíduos durante os exames de ATM, repetidos após 15 minutos. A alternância é uma mudança na resposta do paciente com relação à presença ou ausência de um sintoma específico. Para tal estudo, 36 pacientes com TMD combinados com controles foram submetidos a exames padronizados repetidos dos músculos mastigatórios e articulação temporomandibular. Os sintomas da articulação temporomandibular foram obtidos com um questionário de classificação. A dor muscular e da articulação foi avaliada pela aplicação de uma pressão pré-determinada com um algômetro sobre 12 locais de palpação pré-designados. Perguntou-se aos indivíduos sobre a presença ou ausência de dor após cada pressão e de sons da articulação antes da auscultação articular temporomandibular. Para os 864 locais de palpação, a proporção de alternância foi de 17,4\% (controles: 18,1\%; pacientes: 16,7\%). Com relação aos sons, houve uma alternância de 15,9\% no grupo de pacientes. Os autores, portanto, sugerem que a alternância dos sintomas do indivíduo é uma possível variável que confunde (explicando algumas das variabilidades 
observadas durante exames repetidos) e que isso deve ser considerado quando se estabelecerem critérios de diagnóstico para as Desordens Temporomandibulares.

MILNER et al. ${ }^{70}$, em 1991, avaliaram a confiabilidade interexaminadores na identificação de sons da ATM. Os sons foram registrados usando um microfone de resposta $50-15.000 \mathrm{~Hz}$ conectado por tubo à cabeça de um estetoscópio localizado sobre a articulação. Os sons produzidos foram registrados em uma fita e colocados em um computador para análise acústica. A análise foi feita em 20 articulações. Seis dentistas especialistas, experientes em diagnóstico e tratamento de TMD e 8 estudantes do curso de odontologia ouviram a fita, classificando cada som em estalido, crepitação leve e forte. A confiabilidade foi apenas razoável em ambos grupos.

NEWHAUSER; YIN ${ }^{74}$, em 1991, mostraram que uma importante característica do teste diagnóstico é a teoria envolvida na explicação de seu mecanismo de ação e a patofisiologia de sua relação com a doença ou condição em questão. Segundo os autores, é possível usar um teste que não tenha teoria subjacente ou explicação para seu relacionamento à doença em questão, ou seja, numa situação de cuidado clínico, se tais testes mostram consistentemente um relacionamento à doença, é sensato usá-los por causa desta confiabilidade, sem considerar a validade da ciência subjacente, sugerindo, então, que estes testes caiam na categoria "eu não sei, apenas funciona".

JENSEN et al. ${ }^{45}$, em 1992, estudaram a sensibilidade e o limiar de dor nos músculos cefálicos em uma população geral. Para tal estudo foram utilizados 740 indivíduos (383 homens e 352 mulheres, com idade entre 25-64 anos). Primeiramente, foram feitos exames dentários, da saúde geral e a sensibilidade registrada através de uma escala de 0 a 3 pela palpação executada pelos $2^{\circ}$ e $3^{\circ}$ dedos, fazendo uma pressão firme e com pequenos movimentos rotativos, realizados por um dentista experiente e treinado. Depois, o exame de limiar de dor à pressão (LDP) foi realizado em outra sala por uma enfermeira treinada com uso de um algômetro eletrônico. Ambos os examinadores desconheciam as reclamações de dor de cabeça dos envolvidos na pesquisa. Como resultado, os autores verificaram que 
os músculos mais sensíveis à palpação foram o pterigóideo lateral (55\%), o trapézio (52\%) e o esternocleidomastóideo (51\%), sendo os músculos frontal e temporal posterior os menos sensíveis nos indivíduos normais. As mulheres foram mais sensíveis que os homens em todos os músculos examinados pela palpação manual. No total, o grupo de jovens foi mais sensível do que o grupo mais velho. Os LDP nos músculos temporais mostraram-se mais baixos nas mulheres do que nos homens e, de uma maneira geral, os limiares aumentaram com a idade. Portanto, os autores verificaram que num exame clínico de rotina de pacientes com dor de cabeça, talvez os músculos masséter superficial, frontal e posterior possam ser excluídos porque exibiram pouca sensibilidade e que os músculos trapézio, esternocleidomastóideo e temporal anterior poderão ser incluídos, devido a sua alta sensibilidade.

Em 1992, KROGSTAD et al. ${ }^{54}$ procuraram determinar se as diferenças de sexo em relação aos sintomas musculares eram estabelecidos em pacientes aos 19 anos de idade. Para tanto, 51 jovens do sexo masculino e 47 do sexo feminino foram examinados por questionário com relação à função de seu sistema mastigatório, freqüência de dores de cabeça, dores no pescoço, nos ombros e lombar, além de passarem por um minucioso exame clínico, incluindo palpação em 12 locais feitos de ambos os lados, adotando como critério de relato da dor: "sim ou não". Os autores verificaram que para todas as variáveis no questionário, as mulheres relataram sintomas mais freqüentes do que os homens. De todos eles, $50 \%$ tinham os músculos sensíveis na palpação, tendo o temporal, o masséter e o digástrico apresentando o maior número de locais sensíveis, registrados, novamente, mais freqüente nas mulheres. O número de músculos do pescoço e ombros clinicamente sensíveis correlacionou-se com o número de músculos mastigatórios sensíveis. Os autores concluíram que as mulheres apresentaram mais sintomas musculares do que os homens.

Em 1992, segundo WHITNEY; VON KORFF ${ }^{104}$, o curso da dor associada às DTM e outras condições de dor crônica é tipicamente episódica e que a melhora no nível da dor subseqüente ao tratamento completo pode ser devido a: 1) efeitos específicos do tratamento; 2) efeitos não específicos do tratamento (placebo) ou; 3) 
regressão à média. Para esse relatório, a magnitude da regressão à média devido ao tratamento é estimada comparando-se indivíduos que procuraram por tratamento de dor da DTM ( $\mathrm{n}=147)$ a uma amostra aleatória de indivíduos com dor de DTM que não procuraram por tratamento ( $n=95-$ grupo controle). Os autores verificaram que entre aqueles que procuraram por tratamento houve uma redução significativa de 14,7 pontos na intensidade de dor pela escala de análise visual (EAV), após um ano de acompanhamento. Já no grupo controle não houve redução à média na intensidade da dor, mas relataram intensidade de dor menores na linha de referência do que o grupo que procurou por cuidados médicos. Os autores concluíram que as diferenças entre as mensurações, em ambos os grupos, podem ser atribuídas à regressão à média, sugerindo mais pesquisas para explicar essa regressão, quer seja por efeitos específicos ou não específicos de tratamento.

DWORKIN; LERESCHE ${ }^{19}$, em 1992, propuseram um conjunto de critérios de diagnóstico para pesquisa das DTM rotulada de RDC/TMD com o propósito de permitir uma padronização e reprodução de resultados entre os pesquisadores. Para isso incluíram nesse estudo alguns critérios em relação à palpação muscular e da articulação como: a) Pressionar sobre o local selecionado usando as extremidades dos dedos indicador e o médio, usando uma pressão de 2 libras para os músculos extra-orais e 1 libra para a articulação e os músculos intra-orais. b) Durante a palpação, deve-se usar a mão oposta para apoiar a cabeça fornecendo assim uma melhor estabilidade. c) O paciente deverá estar numa posição de repouso. d) Para assegurar a palpação no lugar correto, deve-se mandar o paciente levemente apertar os dentes e, então, relaxar. e) Deve-se palpar numa extensa área para detectar o local exato da sensibilidade. f) Antes de começar a palpação, o examinador deverá falar ao paciente para registrar a dor sentida durante a palpação, ou seja, caso o paciente sinta dor, o mesmo deverá marcar se essa dor é suave, moderada ou severa. Além disso, os autores descreveram algumas especificações sobre os locais que deverão ser palpados: a) Temporal (posterior): deverão ser palpadas as fibras posteriores, atrás das orelhas, diretamente acima das mesmas. b) Temporal (médio): deverão ser palpadas as fibras localizadas $2 \mathrm{~cm}$ lateralmente ao bordo lateral da sobrancelha. c) Temporal (anterior): deverão ser palpadas as fibras acima da fossa 
infratemporal, imediatamente acima do processo zigomático. d) Origem do masséter: deverão ser palpadas as fibras localizadas em uma área $1 \mathrm{~cm}$ imediatamente à frente da ATM e abaixo do arco zigomático. e) Corpo do masséter: deverão ser palpadas as fibras logo abaixo do arco zigomático, na borda anterior do músculo. f) Inserção do masséter: deverão ser palpadas as fibras em uma área localizada $1 \mathrm{~cm}$ superior e anterior ao ângulo da mandíbula. Foram feitas também especificações para outros músculos como o digástrico, pterigóideo medial, lateral, etc.

Em 1992, CHUNG; UM; $\mathrm{KIM}^{9}$ avaliaram a confiabilidade intra e interexaminadores na obtenção do limiar de dor à pressão nos músculos da cabeça e pescoço. Para tal estudo, foram utilizados 40 estudantes de odontologia (20 a 27 anos). Foram feitas duas medições com intervalos de 5 min por 2 examinadores, a uma força de $40 \mathrm{KPa} / \mathrm{s}$. Os seguintes músculos foram medidos: temporal anterior, médio e posterior, masséter profundo, anterior e inferior, pterigóideo medial, digástrico posterior, esternocleidomastóideo superior e médio, trapézio. Uma comparação com informações obtidas dos músculos contralaterais não demonstraram diferenças estatisticamente significantes. Houve obtenção de uma excelente confiabilidade entre os examinadores em todos os músculos, com exceção do pterigóideo medial e do esternocleidomastóideo médio, medidos nos homens. Os autores demonstraram que o algômetro eletrônico poderia ser indicado para avaliação do LDP dos músculos da cabeça e pescoço em estudos clínicos e experimentais.

Em 1992, LE RESCHE et al. ${ }^{58}$ investigaram a maneira como comportamentos específicos de expressão (relato verbal do nível de dor e a freqüência da emissão de expressões faciais não-verbais específicas de dor) podem ser alterados durante o curso de uma condição de dor crônica. Para isso, 36 mulheres com dor crônica de DTM (duração acima de 6 meses) foram comparadas a 35 casos recentes (duração menor ou igual a 2 meses). Todos, após o preenchimento de questionários (avaliando depressão, ansiedade, aborrecimentos, etc.), foram filmados durante um período de repouso e submetidos a 2 condições dolorosas: dor experimental a frio e pressão à dor decorrente da palpação dos músculos mastigatórios e de ATM. A escala de análise visual (EAV) também foi 
usada. Os resultados indicaram que em ambos os grupos não houve diferenças nas auto-avaliações de ansiedade, depressão e estresse diário. Os dois grupos também demonstraram estratégias similares para lidar com sua dor, apesar dos casos crônicos terem demonstrado uma maior tendência a exagerar sua dor. As auto-avaliações de dor facial espontânea, bem como as medidas verbais da dor ao exame clínico e estímulo experimental de frio e pressão não revelaram diferenças entre os grupos. Por outro lado, os níveis de expressão facial de dor foram bem maiores entre os casos crônicos, sob todas as condições de experimentos. O número de locais relatados como dolorosos não foram diferentes nos dois grupos, como também o relato de dor.

Em 1993, ATWOOD et al. ${ }^{1}$, compararam a escala categórica de 2 pontos (usados no Índice Craniomandibular) com a escala de 4 pontos na avaliação da sensibilidade de palpação do músculo e ATM nas DTM. Para tal estudo foram utilizados 23 pacientes ( 1 homem, 22 mulheres com idade entre 23 e 67 anos) com DTM. Os pacientes foram categorizados baseando-se nas suas histórias e exames clínicos, como tendo etiologia muscular primária (11), muscular e ATM (11) e somente etiologia da ATM (1 paciente). Foram realizadas palpações em 36 músculos e em 6 locais da ATM, de acordo com o protocolo de exame ICM, aplicando uma pressão de 3 libras para palpação extra-oral e uma libra para palpação intra-oral. Um único examinador realizou todos os exames clínicos, após praticar extensivamente para padronizar sua técnica antes de começar seu estudo. O índice de palpação da escala categórica de 2 pontos ( 0 = nenhuma dor relatada e 1 = dor relatada) foi aplicado nos músculos e ATM na primeira consulta, e novamente após 6 semanas. O índice de palpação da escala de 4 pontos foi aplicado simultaneamente com o índice de 2 pontos e repetidos, também, após 6 semanas do tratamento. O examinador graduou cada resposta dos pacientes na escala de $0-3$. Avaliações subjetivas dos sintomas foram registradas pela escala de análise visual (EAV) para cada paciente, 3 vezes ao dia (manhã, tarde e noite). Todos os pacientes receberam um dos três tratamentos: placa oclusal (8 pacientes), instrução intensiva para relaxamento e estresse (6 pacientes) e placa oclusal e instrução intensiva para relaxamento e estresse (9 pacientes). A escala categórica de 4 pontos refletiu uma maior diminuição na sensibilidade do músculo e da articulação nas 6 semanas seguintes aos exames do 
que a escala categórica de 2 pontos, com os pacientes apresentando uma melhora de $6,39 \%$ contra $14,99 \%$ obtidos pela escala de 4 pontos.

Segundo DOUGLAS ${ }^{15}$, em 1993, para avaliar a eficácia de um teste diagnóstico deve-se observar os seguintes critérios: a) exatidão (validade), que reflete se o teste realmente mede o que é pretendido medir; b) precisão (confiabilidade), que reflete se os resultados dos testes podem ser repetidos pelo mesmo ou diferentes diagnósticos; c) sensibilidade, que mede a proporção de pacientes doentes corretamente identificados como positivo; d) especificidade, que mede a proporção de pacientes livres de doenças identificadas corretamente como negativa; e) valor preditivo positivo e negativo, que é calculado e indica o número correto chamados de doenças e não doenças, respectivamente a partir de todos chamados de doença. Ainda segundo o autor, testes com alta razão de probabilidade são melhores do que aqueles com baixa razão de probabilidade, da mesma maneira que testes com alta razão positiva verdadeira e baixa razão de falso positivo são melhores discriminadores da doença. Além disso, DOUGLAS considerou que para um teste ser aceito pela comunidade científica cinco perguntas deveriam ser respondidas: 1) O mérito técnico do teste pode ser avaliado e comparado com o mérito técnico de outros testes?; 2) Os parâmetros de teste têm sido avaliados em termos de sensibilidade, especificidade, exatidão, valores preditivos e precisão? 3) O uso do teste melhora a saúde do paciente? 4) O custo efetivo do teste foi avaliado? 5) Um gasto adicional é justificado pelo aumento da efetividade ou pela prevenção de outros gastos?

CARLSON et al. ${ }^{4}$, em 1993, fizeram uma comparação da função psicológica e fisiológica entre pacientes com dor muscular e pacientes assintomáticos (grupo controle). Para tal estudo, utilizaram 34 pacientes sintomáticos e 18 assintomáticos. Os pacientes foram submetidos a vários testes fisiológicos (atividade eletromiográfica, freqüência cardíaca, nível de pressão) durante condições de repouso, estresse mental e relaxamento. Os autores concluíram que os pacientes com dor relataram uma maior ansiedade e uma maior sensação de tensão muscular do que o controle, e que durante o estresse pacientes com dor tinham uma maior freqüência cardíaca e pressão sistólica do que o controle, e que a atividade 
eletromiográfica na região do masséter não apresentou diferença entre os dois grupos observados. Portanto, os autores põem em dúvida a hiperatividade muscular como causa de dor muscular.

De acordo com MOHL ${ }^{71}$, em 1993, o diagnóstico "gold standard" para DTM é baseado na avaliação da história do paciente e exame clínico suplementado, quando apropriado, pelo uso de radiografias. A confiabilidade e validade das modalidades de diagnóstico devem ser comparadas sempre em relação a esse gold standard. Segundo o autor, várias revisões da literatura têm concluído que a confiabilidade, validade, sensibilidade e especificidade de diagnóstico no uso de aparelhos eletrônicos (Sonografia, EMG, etc.) no diagnóstico da DTM não têm sido estabelecidos, relatando geralmente uma sensibilidade elevada e uma especificidade diminuída, levando como conseqüência a um diagnóstico falso positivo nos indivíduos do grupo controle.

GOULET; CLARK; FLACK ${ }^{33}$, em 1993, com o propósito de desenvolverem um treinamento e um protocolo de calibração entre os examinadores a fim de permitir uma consistência de achados clínicos durante exame repetido, avaliaram a habilidade de 4 examinadores treinados e calibrados para aplicar consistentemente pressão com os dedos dentro de 2 limites de pressão: alta $(1,5-2,1 \mathrm{~kg})$ em 4 músculos: frontal, masséter superficial, profundo e temporal anterior e baixa $(0,5-1,1 \mathrm{~kg})$ para a ATM e testaram a habilidade de examinadores parelhados para localizar precisamente os mesmos locais de palpação. Anterior ao estudo, cada examinador recebeu um protocolo escrito com todas as instruções, além de participarem de um programa de calibração realizado com ajuda de um algômetro, com o propósito de obter o mesmo padrão de aplicação de força, além de como localizar precisamente os locais previamente determinados para palpação. Esse processo de calibração durou cerca de 3 meses. Os autores verificaram que somente um examinador falhou na realização do limite de pressão alta solicitada (79\%), comparado a um índice de sucesso global de $89,5 \%$; em relação à aplicação de pressão no limite baixo, os resultados foram mais satisfatórios ainda, variando numa taxa de 0,12 a $0,22 \mathrm{~kg} / \mathrm{cm}^{2}$. A reprodutibilidade das posições marcadas foi avaliada medindo com a escala a 
distância entre os locais selecionados. Exceto para o masséter superficial e temporal anterior, examinadores parelhados selecionaram os locais de palpação dentro de uma distância de $7 \mathrm{~mm}$ em mais de $85 \%$ das vezes. Portanto, os autores mostraram, nesse estudo, a capacidade de examinadores treinados em desempenhar consistentemente tarefas técnicas para a reproducibilidade dos procedimentos de palpação manual.

Em 1993, BRYANT ${ }^{3}$ acreditou que o aumento ou diminuição da dor relatados pelos pacientes podem ser influenciados por sua memória de dor que, por sua vez, é influenciada pelo seu estado de saúde geral, ou seja, pelo nível de depressão, ansiedade e ânimo que o paciente está vivendo naquele momento.

Em 1993, de acordo com CLARK; DELCANHO; GOULET ${ }^{10}$, os dados colhidos pelo exame clínico tradicional indicam que a sensibilidade dos músculos mastigatórios e da ATM são os aspectos mais consistentes numa avaliação de DTM, embora esses dados sejam bastante questionados em se tratando de pesquisas clínicas. Segundo os autores, o método de pressão digital (isto é, ponta do dedo) permanece como um gold standard e quaisquer novos métodos que surjam devem ser comparados a ele, para que todas suas vantagens e possíveis dificuldades sejam identificadas.

CHUNG; KIM; KIM , em 1993, avaliaram a confiabilidade inter e intraexaminadores na medição do limiar de dor à pressão (LDP) na cápsula lateral e posterior da ATM. Verificaram, também, se a influência do sexo e do lado a ser palpado afetaram o LDP, como também a validade do uso do algômetro em indivíduos saudáveis e não saudáveis. Para tal estudo foram examinados 39 indivíduos normais (20 homens e 19 mulheres) e 30 mulheres com capsulite na ATM (25 capsulite posterior e 21 lateral) por um algômetro eletrônico (duas vezes com um intervalo de 5 minutos entre a primeira e a segunda palpação) por 2 examinadores. Os autores obtiveram boa confiabilidade inter e intra-examinadores com o algômetro eletrônico. Além disso, nenhuma diferença significante foi registrada entre os lados direito e esquerdo nas cápsulas da ATM, mas as mulheres obtiveram LDP inferiores aos homens. Diferenças estatisticamente significantes foram encontradas entre o LDP de 
mulheres saudáveis e não saudáveis. Assim, os autores concluíram que, o algômetro eletrônico pode ser recomendado para a avaliação de sensibilidade da cápsula da ATM em estudos clínicos e experimentais.

Existe uma suposição geral de que DTM, dor e sensibilidade dos músculos da mastigação podem ser causados por hiperatividade muscular, de acordo com PAESANI et al. $^{81}$, em 1994. Por isso, esses autores avaliaram 5 homens e 5 mulheres assintomáticos e 5 mulheres com sinais e sintomas de DTM com o objetivo de obter informações sobre a reproducibilidade dos sinais de repouso eletromiográfico dos músculos temporal anterior e masséter. Essa atividade (EMG) foi registrada 3 vezes em 5 sessões separadas. Os resultados sugeriram que os valores das eletromiografias feitas em várias sessões não são reproduzíveis, e que valores de sessões sucessivas são questionáveis. Isso poderia dificultar a correlação do tratamento com níveis de atividade muscular e, além disso, não foram observadas diferenças estatisticamente significantes entre os grupos.

O efeito do apertamento de dentes e abertura mandibular no limiar de dor à pressão (LDP) nos músculos mastigatórios foram avaliados por MCMILLAN; LAWSON $^{64}$, em 1994. Para tal objetivo, um algômetro foi usado para medir o LDP em várias regiões dos músculos masséter e temporal em diferentes magnitudes de apertamento dental e abertura mandibular. Dez estudantes de odontologia (homens, com idade entre 22 a 30 anos) sem história de DTM participaram do estudo. Os autores verificaram que o LDP aumentou em todas as áreas registradas como contração muscular associada com aumento de apertamento dental. O LDP não foi afetado quando a abertura mandibular mudou. Não houve diferença no LDP nos músculos masséter e temporal quando o músculo foi submetido a diferentes magnitudes de apertamento e abertura bucal. Os autores sugeriram que quando medições quantitativas do LDP dos músculos mastigatórios são planejadas numa população de paciente, além do controle do tamanho do medidor da dor e a taxa de carga, o grau de apertamento dental deveria também ser levado em consideração.

DAHLSTRÖN et al. ${ }^{13}$, em 1994, avaliaram um programa de treinamento com o propósito de calibrar os examinadores no exame das Desordens 
Temporomandibulares. Para isso, 8 examinadores (seis dentistas, um assistente dental e um higienista dental) participaram como examinadores, sete dos quais foram instruídos e treinados em todas as variáveis do exame pelo oitavo, um examinador muito experiente. A sessão de treinamento de calibração incluiu assistir a um vídeo de instrução de 19min e uma demonstração clínica, de 40min, da técnica de exame feito pelo mesmo examinador, além de ter sido praticado em alguns pacientes. Esse treinamento durou 5 horas e foi seguido após o almoço, por teste de calibração cega em 12 indivíduos. Seis pacientes com sintomas e 6 assintomáticos (10 mulheres e 2 homens) participaram do estudo. O Índice Craniomandibular (ICM) foi usado como instrumento de avaliação. Todos foram avaliados em ordem aleatória pelos 8 examinadores, independentemente, e cada examinador e indivíduo não sabiam dos achados do outro examinador. O exame durou cerca de 10 minutos. Os autores verificaram que a concordância dentro de todo o grupo de examinadores foi baixa e que o treinamento aumentou a probabilidade de se registrarem corretamente os sinais, principalmente naqueles examinadores mais experientes. Concluiu-se que o programa de 5 horas não foi suficiente para criar uma confiabilidade aceitável entre múltiplos examinadores. Os autores sugerem que o treinamento deve ser mais extensivo.

LOBBEZOO-SCHOLTE et al. ${ }^{62}$, em 1994, verificaram a confiabilidade interexaminadores através de 6 testes de ortopedia (abertura passiva, movimento ativo, movimento de rotação e translação, compressão, resistência e palpação) em um grupo de 79 pacientes (76\% mulheres, com idade média de 35 anos) com sinais e sintomas de DTM, que foram subdivididos em 3 subgrupos de pacientes: desordem miogênica, desordem artrógena e um terceiro contendo sinais e sintomas de ambos. Os testes foram repetidos duas horas após o término do primeiro. Embora os testes ortopédicos mostrassem diferentes resultados de confiabilidade, a confiabilidade total na determinação dos 3 sintomas principais de DTM foi satisfatória. Nos subgrupos, os sinais e sintomas artrógenos puderam ser determinados confiavelmente com 0 conjunto dos 6 testes, enquanto a confiabilidade dos testes na determinação da dor e sons no grupo muscular foi baixo. Os autores concluíram que os testes são bem ajustáveis para avaliar os sinais e sintomas artrógenos, mas que o clínico deve estar 
ciente dos resultados errôneos desses testes na avaliação de dor de origem miogênica.

GRAY; DAVIES; QUAYLE ${ }^{36}$, em 1994, fazendo uma abordagem da necessidade do exame dos músculos mastigatórios afirmaram que o exame de sensibilidade dos músculos é importante porque permite detectar um possível sinal de parafunção. Segundo os autores, a sensibilidade muscular pode ser devido, tanto à alteração na oclusão, quanto a uma mudança subconsciente no padrão de mastigação do paciente para evitar a interferência. Essa sensibilidade pode variar com o estágio e o progresso da desordem. Com relação à sensibilidade, os autores acham que todos os músculos devem ser palpados onde se ligam ao osso, sendo que raramente o corpo do músculo é sensível. Afirmaram, também, que o masséter é sensível em pacientes que tenham o hábito de apertar os dentes e o temporal em pacientes que tenham o hábito de bruxismo, pois os pacientes que reclamam de dor de cabeça temporal, freqüentemente demostram sensibilidade neste músculo. A sensibilidade do pterigóideo lateral e medial pode ser difícil de se detectar devido a sua difícil acessibilidade.

REID; GRACELY; DUBNEN² ${ }^{84}$ em 1994, avaliaram a relação do limiar de dor à pressão através do algômetro nos músculos masséter profundo, masséter superficial (origem e inserção) e temporal anterior em pacientes com Desordens Temporomandibulares de origem miogênica. Além disso, a influência do tempo, o lado e o local de maior dor indicados pelo relato do paciente, o local e o lado facial na medida do limiar de dor à pressão (LDP) foram avaliados. Para tal estudo, utilizaram 29 pacientes (28 mulheres, 1 homem; média de idade 28,5 \pm 5 anos), e 11 no grupo controle (11 mulheres; média de idade $39 \pm 12$ anos). Os pacientes foram diagnosticados com DTM, com dor muscular por pelo menos 3 meses. Os pacientes do grupo controle não possuíam sinais e sintomas de DTM. Cada paciente participou de 2 sessões separadas por um intervalo de 1 semana. A localização dos locais dos músculos sensíveis foi detectada manualmente e registrada num guia transparente, usado para localizar novamente essas áreas em cada sessão. Foi solicitado aos pacientes para identificar seu "lado mais doloroso" antes de se obter a medição do 
limiar de dor à pressão (LDP). Cada medição do limiar de dor à pressão foi definido pela média de três tentativas usando um algômetro de pressão. As medidas foram repetidas após 30 minutos para avaliar a confiabilidade intra-sessões. Obtiveram como resultado que o LDP médios dos pacientes, não dos controles, diferiram significativamente após 4 sessões $(p<0.05)$. Os LDP médios também diferiram entre os grupos $(p<0.02)$. Os LDP diferiram significativamente entre todas as localizações $(p<0.0001)$ mas não diferiram entre os lados esquerdo e direito. A comparação dos valores de LDP obtidos nos lados mais dolorosos designados pelos pacientes não revelaram diferenças significativas $(p=0.51)$. Os LDP no grupo controle diferiram bastante entre os vários locais examinados mas, como nos pacientes, não diferiram entre os lados esquerdo e direito. A confiabilidade do LDP obtido com o algômetro na mesma sessão (intervalo de 30min) e entre sessões (intervalo de 1 semana) foi satisfatório e similar entre pacientes e controle. Por outro lado, a confiabilidade do LDP lado a lado em pacientes foi menor do que no grupo controle, apesar dessa diferença não ser significativa. Portanto, o algômetro foi capaz de controlar o índice de aplicação de pressão em uma população de pacientes com DTM de origem miogênica. Também os LDP foram altamente reproduzíveis intra e entre sessões e significativamente mais baixos em pacientes quando comparado ao grupo controle.

WIJER et al. ${ }^{106}$, em 1995, avaliaram a confiabilidade interexaminadores de testes ortopédicos e palpação, rotineiramente usados no diagnóstico clínico de DTM. Os testes foram executados por um dentista e um fisioterapeuta em 79 pacientes (60 mulheres - idade 16 a 69) e 19 homens (idade 18 a 50). A confiabilidade interexaminadores dos testes medindo a abertura da boca máxima e o registro do estalido durante a abertura foi alta. A confiabilidade interexaminadores em relação à palpação dos músculos mastigatórios e ATM foi moderada $(\mathrm{K}=0.51)$ e razoável $(\mathrm{K}=$ 0.33), respectivamente. Os autores concluíram que a maioria das variáveis determinadas durante os movimentos ativos podem ser medidas com confiabilidade satisfatória, ao passo que variáveis para outros testes não são medidas com a mesma confiabilidade com base na pontuações de KAPPA. É recomendado, portanto, que os clínicos calibrem suas técnicas regularmente para melhorar a confiabilidade de resultados na prática diária. 
KIM et al. ${ }^{50}$, em 1995, avaliaram o limiar de dor à pressão (LDP) da região da cabeça e pescoço em 31 mulheres (13 a 50 anos) que sofriam de cefaléias tensionais episódicas e em 32 mulheres (15 a 46 anos) como controle, com o uso de um algômetro eletrônico. A análise estatística revelou que os valores obtidos em ambos os grupos foram diferentes, mas os valores obtidos nos músculos do lado direito não foram estatisticamente diferentes dos valores obtidos no lado esquerdo. LDP do grupo de pacientes foi mais baixo do que o grupo controle para os músculos esternocleidomastóideo superior, médio e a inserção do trapézio, mas não foram estatisticamente diferentes do temporal anterior, médio e posterior, masséter profundo, anterior e inferior, pterigóideo medial, digástrico posterior e trapézio superior. Os autores concluíram que o limiar de dor à pressão (LDP) da região da cabeça e pescoço deveria ser considerado no diagnóstico de cefáleia tensional, sugerindo que os músculos cervicais são mais sensíveis do que os músculos mastigatórios em indivíduos com dor de cabeça dessa natureza.

Em 1995, WANMAN ${ }^{101}$ coordenou uma pesquisa epidemiológica de sensibilidade muscular da mandíbula, pescoço, ombro, braço, mão e panturrilha e da prevalência dos sinais e sintomas das Desordens Craniomandibulares. Para tal pesquisa foram utilizados 276 indivíduos divididos em 144 para o grupo controle que não tinha sensibilidade, 59 com sensibilidade somente nos músculos da mandíbula, 26 nos músculos do pescoço e ombro, 39 nos da mandíbula, pescoço e ombro, 8 com sensibilidade em todos os músculos palpados do pescoço, ombro, braço, mão e panturrilha. Para fazer o exame foram utilizados 6 dentistas que, anteriormente ao estudo, participaram de um programa de calibração, onde a confiabilidade interexaminadores foi testada, obtendo-se um índice de sucesso de $81 \%$ a $87 \%$. Foi encontrado que as mulheres tinham sensibilidade à palpação significativamente mais freqüente do que os homens. O principal achado desse estudo foi a presença de uma proporção mais alta de sinais e sintomas de DTM no grupo que tinha sensibilidade dos músculos mandibulares, do pescoço e ombro e no grupo que tinha sensibilidade generalizada, do que no grupo controle. O autor concluiu que na pesquisa epidemiológica e clínica de DTM, uma distinção local, regional e geral deve ser feita, uma vez que a etiologia pode diferir. 
SVENSSON et al. ${ }^{95}$, em 1995, compararam as medidas do limiar de dor à pressão (LDP) e curvas estímulo-resposta $(S-R)$ nos músculos masséter e dedos indicadores de 11 mulheres pacientes com dor muscular crônica, com 11 indivíduos de controle assintomáticos. Condições hiperalgésicas experimentais e hipoalgésicas nos músculos masséter do grupo controle foram induzidos pela injeção intramuscular de $5 \%$ salina e anestesia local, respectivamente. As curvas estímulo-resposta (S - R) têm sido amplamente usadas para avaliar reações cutâneas hiperalgésicas e hipoalgésicas. Então, os autores resolveram aplicá-la no estudo da dor e, para isso, uma pressão constante foi aplicada por 5 segundos e a intensidade de dor foi pontuada através da escala de análise visual (EAV), que foram mostrados na tela do computador. Cinco intensidades de pressão diferentes foram aplicadas com $2 \mathrm{~min}$ entre estímulos sucessivos. Os autores concluíram que os LDP obtidos nos músculos masséter dos pacientes com dor foram significantemente inferiores ao do grupo controle. As rampas médias das curvas $S-R$ foram bem mais íngremes para os pacientes com dor nos músculos masséter do que no grupo controle. Não houve diferenças significantes estatisticamente nos LDP ou curvas $S-R$ para o dedo indicador. Os LDP nos músculos masséter do grupo controle não foram afetados pela injeção de $5 \%$ de solução salina, entretanto as rampas das curvas $S-R$ para os músculos masséter foram bem mais íngremes para os valores de injeção salina comparadas aos valores básicos. A injeção de anestesia local nos músculos masséter do grupo controle aumentou os LDP e reduziu as rampas das curvas $S-R$ significantemente quando comparadas aos valores básicos. Os resultados sugerem que os LDP e as curvas $S$ - R são instrumentos valiosos para a descrição quantitativa da dor muscular crônica e experimental.

Em 1995, SUVINEN; READE ${ }^{94}$ afirmaram que a avaliação de dor é uma área complexa de pesquisa e sua natureza subjetiva e particular de experiência permite que só possa ser medida pela descrição do paciente ou observando seu comportamento. Além disso, segundo os mesmos autores, a dor é uma experiência complexa multifatorial que inclui não somente as dimensões discriminativas sensoriais, mas também fatores afetivos, de motivação e cognitivos, que se interrelacionam afetando a resposta da dor e a expressão dos pacientes. 
Em 1995, segundo FRICTON ${ }^{26}$, os examinadores que fazem experimentos envolvendo dor orofacial têm se confrontado com muitos problemas, tais como dificuldade na obtenção de grupos controle, falta de uma amostra de tamanho adequado após os critérios de exclusão e inclusão, já que muitos pacientes desistem da pesquisa no decorrer de sua execução, dificuldade de um processo aleatório duplo cego por parte dos examinadores, variabilidade natural dos sinais e sintomas, falta de conhecimento de progressão natural da doença, intervenções não padronizadas, medidas não testadas e finalmente dificuldade de mensuração da severidade das desordens para determinar o sucesso do tratamento.

De acordo com STOREY; RUGH ${ }^{93}$, em 1995, para determinação da eficácia de um diagnóstico através de pesquisa, deve-se: a) estabelecer uma equipe de pesquisa; b) selecionar um estaticista que seja familiar com a pesquisa; c) fazer uma revisão na literatura para determinar que pesquisas foram feitas para documentar a eficácia do procedimento diagnóstico; d) estabelecer critérios para que o teste diagnóstico que está sendo avaliado seja administrado de forma oculta, isto é, os clínicos que administraram e computaram o procedimento não devem conhecer a verdadeira condição do paciente; e) determinar os gold standards atualmente aceitos para identificar pacientes que têm a doença (de acordo com os autores a comparação cega/oculta com um gold standard é o método mais aceito para testar a eficácia de um procedimento diagnóstico); f) estabelecer critérios específicos para a presença ou ausência da doença; g) estabelecer critérios de inclusão e exclusão; h) calibrar os examinadores, ou seja, se mais de um indivíduo estiver administrando o procedimento de diagnóstico ou determinando a presença ou ausência de doença, será necessário treiná-los e testá-los em relação a sua confiabilidade (recomenda-se que um examinador seja utilizado para aplicar o novo procedimento de diagnóstico e outro examinador para determinar a presença ou ausência da doença; i) obter consentimento dos pacientes.

Em 1995, ELLERMEIER; WESTPHAL ${ }^{22}$ investigaram as diferenças de gênero na percepção da dor e reações da pupila ao estímulo doloroso por pressão. Participaram do experimento 20 indivíduos (10 homens e 10 mulheres), que eram 
livres de dor aguda e de medicação analgésica. No primeiro estudo, os 20 indivíduos foram submetidos à aplicação de pressão com o uso doalgômetro por 20 segundos, classificando sua dor numa escala ordinal de 0 a 5, com as mulheres relatando maior dor a um forte estímulo do que os homens. Quando a pressão foi diminuída, nenhuma diferença foi relatada entre os dois grupos. No estudo 2, 16 indivíduos foram expostos ao mesmo estímulo de pressão doloroso enquanto suas reações da pupila usando-se pupilometria de vídeo infravermelho, eram medidas, sendo que as mulheres apresentaram uma maior dilatação da pupila somente em altos níveis de pressão.

LOBBEZOO; SCHOLTE et al. $^{63}$, em 1995, a fim de possibilitarem uma escolha mais direta do tratamento e um melhor prognóstico, fizeram um estudo com o objetivo de comparar a presença de sinais e sintomas associados a DTM nos quatro principais subgrupos de pacientes: problemas de origem muscular, desarranjos internos com e sem redução e osteoartrose. Para isso, foram recrutados 522 pacientes todos tendo sinais e sintomas de DTM. Antes do início do estudo, os dentistas foram calibrados em relação aos critérios de diagnóstico. As informações foram coletadas por intermédio de um questionário e durante um extensivo exame clínico. Os resultados mostraram que não houve uma diferença estatisticamente significante nos 4 subgrupos de diagnóstico com relação a fatores oclusais, trauma e hábitos parafuncionais. Os grupos diferiram consideravelmente em relação a características como dor variável, sinais de DTM, relato de hábitos parafuncionais, fatores psicossociais e fatores gerais de saúde. Os autores afirmaram que quase todos os fatores associados com DTM podem influenciar o início e a perpetuação de diferentes desordens e, portanto, futuras pesquisas são necessárias para evidenciar essa variável.

De acordo com GRACELY; REID ${ }^{35}$, em 1995, a avaliação subjetiva da dor orofacial é criticamente importante para a prática clínica e para o pesquisador que investiga os mecanismos tanto de dor quanto de seu controle. Contudo, um clínico ou investigador que deseja medir a dor orofacial rapidamente, encontra o problema em escolher um método específico com a abundância de medidas de dor disponíveis. 
Segundo os autores, há muitas escalas e pouco consenso e grande parte dessa confusão é devido mais a uma falta de orientação específica em relação às escalas do que precisamente a uma questão clínica ou experimental avaliada pela escala. A escolha de uma escala para medir a dor orofacial pode ser simplificada pela organização dos métodos os quais abrangem desde a avaliação da eficácia do tratamento até investigações de mecanismos analgésicos. Ainda, segundo o autor, a sensação de dor não é uma entidade simples. Como outras sensações, tais como a do paladar e da temperatura, a dor pode ser descrita por uma dimensão de intensidade e uma dimensão de desconforto ou sofrimento e essas distorções podem ser difíceis de serem detectadas. Portanto, para facilitar esse discernimento, utilizouse de uma linguagem descritiva de intensidade sensorial (por exemplo, suave, média, intensa) e desconforto (por exemplo, desagradável, sofrimento, insuportável). Portanto, a dor é conceitual e é definida somente através de relato verbal, ou seja, a dor pode ser realmente medida por uma descrição verbal/oral de experiência subjetiva. Todas as outras medidas em homens ou animais são somente deduções/conclusões dessas experiências. O relato oral/verbal é uma medida de mensuração da dor, e as medidas não orais são validadas por comparação a este padrão.

Em 1996, CECERE; RUF; PANCHERZ ${ }^{6}$ avaliaram a reprodutibilidade dos registros EMG dos músculos mastigatórios, analisando variantes como o tempo entre os registros e o reposicionamento dos eletrodos. Concluíram que os erros se estenderam entre 5 e $63 \%$, dependendo do intervalo de tempo entre os registros, dos músculos considerados e das funções desenvolvidas (masséter - média de 27,2\% e temporal - média de $20 \%$ ). Por causa de sua baixa reprodutibilidade, a EMG dos músculos mastigatórios tem tido valor limitado como instrumento de diagnóstico e avaliação do tratamento, principalmente porque as dores e disfunções musculares podem afetar a precisão dos registros eletromiográficos. Os autores afirmaram que quando os registros foram repetidos em amostras de pacientes assintomáticos, variações individuais consideráveis foram encontradas. 
Segundo ISSELÉE et al. $^{41}$, em 1997, o algômetro consiste de um estimulador conectado a uma unidade de leitura. A extremidade do estimulador tem uma ponta redonda de borracha com um diâmetro de $11 \mathrm{~mm}$, com uma intensidade de 40-50Kpa/s. O paciente é instruído a pressionar um botão no primeiro momento em que sente uma sensação de dor. Quando o botão é pressionado, a pressão aplicada é exposta ao profissional. Para guiar a investigação na aplicação da pressão, um indicador tanto da proporção da variação de pressão aplicada, como também o nível absoluto de pressão são dispostos sobre uma unidade de leitura.

Ainda em 1997, ISSELÉE et al. ${ }^{41}$ também avaliaram o limiar de dor à pressão (LDP) dos músculos masséter e temporal num único dia, com duas sessões separadas por 15min pela manhã e duas sessões à tarde, com o mesmo intervalo, e entre dois dias por um mesmo examinador, com o auxílio de um algômetro eletrônico em 11 homens e 11 mulheres livres de sintomas. Verificaram que para cada músculo, a primeira medida do LDP de uma sessão foi notadamente mais alta do que a última da mesma sessão. Os dados também demonstraram uma boa reprodutibilidade entre sessões e entre os dias. Em conclusão, o presente estudo não encontrou nenhuma influência sistemática na medida LDP com referência ao tempo de registro (manhã/tarde) ou entre dias consecutivos.

OKESON ${ }^{80}$, em 1998, discutiu os efeitos dos impulsos nociceptivos nos centros cerebrais superiores e chamou de modulação da dor aos fatores que influenciam os impulsos que entram e saem, destacando que nocicepção não é dor até que os impulsos alcancem e sejam processados pelo sistema nervoso central superior. Segundo o autor, uma vez que esses impulsos alcançaram os centros superiores, o paciente faz um julgamento da experiência da dor de acordo com, pelo menos, quatro fatores ou condições: 1) o nível de estimulação do tronco cerebral - se um impulso nociceptivo chega a um tronco cerebral normal, calmo, em bom funcionamento, o impulso pode nunca atingir os centros superiores, dessa forma não sendo capaz de desencadear uma resposta significativa. Entretanto, se o mesmo impulso chega a um tronco cerebral com uma formação reticular sobre-regulada e inibição descendente alterada, o impulso pode afetar muito a resposta do córtex 
cerebral; 2) experiências anteriores - o córtex é responsável por armazenar toda a memória das experiências passadas. Há muito já foi reconhecido que uma experiência anterior de dor pode influenciar profundamente, senão realmente gerar dor clínica. De fato, os humanos são sujeitos ao auto-condicionamento, o que pode afetar a resposta à dor. Isso talvez forme a base para a ansiedade, um importante fator de modulação psicológica; 3) estado emocional - quando os impulsos nociceptivos atingem o tálamo, não são apenas direcionados para o córtex, mas também para as estruturas límbicas. Nestes locais é que a experiência dolorosa é avaliada em um nível diferente, um nível emocional. Se a experiência da dor é prolongada, a emoção pode mudar para um senso de desamparo, tristeza ou depressão. O estado emocional do indivíduo no momento em que a dor é iniciada pode influenciar muito a experiência da dor. Se o paciente está calmo e confortável, a experiência da dor é minimizada. Entretanto, se o paciente está excitado, nervoso ou agitado, a experiência da dor é aumentada; 4) particularidades específicas de comportamento - uma vez que o sistema límbico tenha rotulado emocionalmente a dor e o córtex tenha lhe dado, de acordo com experiências passadas, o significado dessa dor, o indivíduo reage com um comportamento específico. Alguns indivíduos podem dar grande significado e emoção à dor e sofrer muito. Outros, experimentando exatamente o mesmo nível de dor, podem lhe dar pequeno significado e emoção e não sofrer tanto. A influência dos centros altos na nocicepção é comumente chamada de "aspectos psicológicos da dor". Infelizmente, isso é freqüentemente usado como uma desculpa ou via de escape por clínicos inexperientes. Em outras palavras, muito freqüentemente, quando o clínico não acha razão somática para a dor, o paciente é levado a acreditar que tenha um problema psicológico. Na medida em que o clínico torna-se mais experiente, começa a entender a existência das muitas possibilidades de diagnóstico e as desordens dolorosas começam a fazer mais sentido. O clínico deve notar que todas as dores, sejam de curta ou longa duração, somáticas ou neuropáticas, lentas ou rápidas, são influenciadas por fatores psicológicos.

Em 1998, GOULET et al. ${ }^{34}$ avaliaram: 1) a reprodutibilidade dos métodos de detecção da sensibilidade de dois músculos mastigatórios e da articulação; 2) a reprodutibilidade das mensurações do movimento mandibular máximo; 3) os fatores 
que influenciam a concordância dos examinadores. Os autores utilizaram uma pressão padrão por 2 segundos sobre quatro locais dos músculos mastigatórios definidos anatomicamente: um local na fronte, como controle, e dois locais da ATM em cada lado da face. Uma técnica usou o algômetro de pressão enquanto a outra técnica exigiu que o examinador treinado aplicasse pressão com a ponta do dedo indicador. Setenta e dois indivíduos (36 pacientes e 36 controles) foram avaliados em um tipo de estudo cego. Os indivíduos controles foram combinados por idade, gênero e raça com os indivíduos com DTM. Cada indivíduo foi examinado duas vezes com cada um dos métodos descritos, numa seqüência aleatória completamente equilibrada por examinadores regulados. Os níveis de sensibilidade foram determinados pelo indivíduo via auto-relato de dor sobre pressão usando um conjunto padronizado de descritores verbais. Os autores verificaram que os coeficientes de correlação intraclasse (ICC) para os métodos de avaliação da sensibilidade alcançaram de 0,220 a 0,739 para a pressão manual e de 0,391 a 0,880 para o algômetro. Os ICC para a mensuração do movimento mandibular foram muito menos variáveis, alcançando de 0,59 a 0,68 para movimentos laterais e de 0,78 a 0,93 para movimento de abertura. Esses resultados indicam de boa a excelente concordância entre examinadores ajustados para mensuração do movimento mandibular e para os métodos de avaliação da sensibilidade nos dois locais do masséter (isto é, superficial e profundo) e os músculos temporais anteriores. Somente uma concordância razoável foi descoberta para os músculos temporais mediais e cápsula lateral da ATM usando estes métodos.

Em 1998, ISSELEE et al. ${ }^{42}$ avaliaram o limiar de dor à pressão (LDP) dos músculos masséter e temporal durante quatro sessões (manhã e tarde dos dias 1 e 3), para testar o desempenho clínico de um novo medidor de dor (algômetro) na medição a curto prazo do LDP. Durante cada sessão, cada ponto de palpação dos músculos mastigatórios foram medidos 4 vezes. Existia um intervalo de poucos segundos entre as medições 1 e 2 e, 3 e 4 e, 5 min entre 2 e 3 . Para tal estudo foram utilizados 20 homens (idade de 22 - 36) e 9 mulheres (21 a 34) livres de DTM. Foi utilizado um molde transparente colocado sobre a face dos indivíduos com o propósito de localizar os pontos destinados à palpação. A força de aplicação exercida com o 
algômetro foi entre 37 e 43KPa/s. Para cada palpação realizada, o primeiro LDP da sessão foi significantemente menor que o segundo na mesma sessão. Similarmente, o terceiro era menor que o quarto. Os valores do LDP entre as sessões da manhã e tarde e entre os dias 1 e 3 não foram significantemente diferentes. Entretanto, quando os valores do LDP foram considerados dentro da mesma sessão, os resultados obtidos foram considerados diferentes. Análises de variação mostraram que a variabilidade entre indivíduos do LDP foi 1,4 a 6,8 vezes mais alta que a variabilidade observada intra ou entre sessões e dias. Nenhuma diferença em relação ao gênero foi encontrada. Os autores comprovaram o bom desempenho clínico desse novo tipo de algômetro.

Em 1998, WAHLUND; LIST; DWORKIN ${ }^{100}$ avaliaram a utilidade e confiabilidade de medidas e métodos no diagnóstico de DTM em pacientes jovens. Para isso, foram utilizados 50 suecos, crianças e adolescentes com idade entre 12 e 18 anos. Os pacientes passaram por repetidos exames clínicos feitos por 2 examinadores calibrados para avaliar sinais e sintomas de DTM e responderam a questionários auto-administrados, especialmente desenvolvido, que apontavam local, dor e sintomas das DTM. Análises interexaminadores e intra-examinadores foram realizadas para o exame clínico e diagnóstico. Os autores verificaram que os valores de confiabilidade variaram de aceitáveis para excelente, em relação ao exame clínico de DTM e questionário. Em relação à palpação dos músculos mastigatórios, com relação à localização e dor, houve uma concordância de 0.82 (KAPPA) interexaminadores e 0.83 intra-examinadores.

Em 1999, CONTI et al. ${ }^{11}$ avaliaram a concordância interexaminadores na detecção de sons da ATM e compararam esses resultados com os resultados obtidos por um sistema computadorizado. Para tal objetivo, utilizaram 43 pessoas, sendo 24 sintomáticos e 19 assintomáticos, sendo a eletrovibrotografia da ATM (EVG) executada em toda a amostra, seguida por inspeção normal da ATM, executada por 2 examinadores, não calibrados, que, também, desconheciam os resultados obtidos pelo EVG. Os autores encontraram uma prevalência de 62.5 e $42.1 \%$ de sons no grupo experimental e controle respectivamente, apresentando um percentual de 
concordância de $32 \%$ a $100 \%$ e índice KAPPA de 0 a 0.4 para todas as condições investigadas: estalidos, crepitação e ruído de hipermobilidade. Os autores concluíram que os sons da ATM são encontrados tanto numa população de pacientes como em indivíduos assintomáticos, mas sua detecção e classificação são difíceis. Processos de treinamento e calibração são sugeridos como meio de otimizar os resultados de concordância. 
3 PROPOSIÇÃO 


\section{PROPOSIÇÃO}

Como observado na Revisão de Literatura, há uma grande diversidade de opiniões em relação à confiabilidade e reprodutibilidade dos métodos de palpação.

Para assegurar a confiabilidade dos dados coletados, a padronização do exame é essencial e uma das maneiras para se conseguir isso, é através da calibração dos examinadores. Para isso, este estudo se propõe a avaliar:

1. a reprodutibilidade interexaminadores na palpação muscular após um programa de calibração;

2. variações na concordância interexaminadores em relação ao tempo;

3. variações de concordância interexaminadores em relação a determinado músculo ou grupo de músculos.

4. variações de concordância interexaminadores em relação aos lados (direito e esquerdo). 
4 MATERIAL E MÉTODOS 


\section{MATERIAL E MÉTODOS}

\subsection{Materiais}

\subsection{1 $\underline{\text { Amostra }}$}

Esta pesquisa foi realizada utilizando-se uma amostra composta por 32 indivíduos divididos em dois grupos (sintomático e assintomático). A seleção desses grupos foi baseada nos seguintes critérios:

\subsubsection{Grupo I (sintomático)}

Composto por 16 indivíduos, proporcionalmente divididos entre mulheres e homens, que apresentaram sinais e sintomas de DTM, com queixas compatíveis com patologias de origem muscular. Foram excluídos aqueles que apresentaram sensibilidade nos músculos provenientes de patologias sistêmicas e portadores de dor de origem dentária, assim como pacientes com distúrbios psicológicos. Todos os 16 indivíduos eram pacientes que buscaram tratamento na Clínica de Disfunções Temporomandibulares da Faculdade de Odontologia de Bauru, da Universidade de São Paulo. 


\subsubsection{Grupo II (assintomático)}

Composto por 16 indivíduos, proporcionalmente divididos entre mulheres e homens, escolhidos aleatoriamente das diversas clínicas (prótese, periodontia, cirurgia e dentística) da Faculdade de Odontologia de Bauru, da Universidade de São Paulo. Os pacientes selecionados para o grupo assintomático não tinham queixas de sintomas de DTM. Também foram excluídos os pacientes com patologias sistêmicas e/ou desordens psicoterápicas.

\subsubsection{Fichas utilizadas para a pesquisa}

\subsubsection{Ficha A (exame inicial da amostra)}

Foi elaborada uma ficha com o propósito de obter os dados do paciente e identificar o grupo (sintomático ou assintomático) a que o indivíduo fazia parte, composta por:

a) nome, endereço, telefone, sexo, idade, estado civil, profissão

b) resumo da história geral das queixas principais (quando presentes)

Anotações relativas às queixas principais relatadas pelos pacientes do grupo sintomático.

c) resumo do exame clínico (sinais e sintomas)

Neste item procurou-se anotar os sinais e sintomas de DTM observados no paciente, ou seja, se possuía crepitação ou estalo na ATM, limitação ou dificuldade de movimentação mandibular (desvio, deflexão), dor nos músculos e na ATM. 
d) impressões diagnósticas (grupo sintomático)

Neste item procurou-se diagnosticar o paciente baseados na anamnese e no exame físico. Através desse diagnóstico, o grupo sintomático foi constituído, sendo o critério de inclusão a presença de patologias de origem muscular. 


\section{UNIVERSIDADE DE SÃO PAULO \\ Faculdade de Odontologia de Bauru}

Pesquisa: Avaliação da reprodutibilidade interexaminadores na palpação muscular, após um programa de calibração.

Orientador: Prof. Dr. Paulo César Rodrigues Conti

Orientado: Carlos Neanes Santos

\section{GRUPO SINTOMÁTICO}

Nome: DN:

Endereço: Bairro:

Cidade: Estado: Fone resid.

Profissão: Fone trab.:

Empresa:

Endereço:

História Geral das Queixas Principais

Resumo do Exame Clínico (sinais e sintomas)

\section{Impressões Diagnósticas}

Mioespasmo

Mialgia

Dor miofascial

Contratura muscular

Fibromialgia

Contração protetora Miosite 
4.1.2.2 Ficha B (utilizada no procedimento de calibração entre os examinadores)

Composta por informações relativas à:
a) quantidade de pressão a ser exercida nos músculos;
b) método de palpação a ser utilizado;
c) método de medição da dor a ser utilizado durante a palpação;
d) procedimentos do exame;
e) localização dos músculos a serem palpados. 


\section{UNIVERSIDADE DE SÃO PAULO}

\section{Faculdade de Odontologia de Bauru}

Pesquisa: Avaliação da reprodutibilidade interexaminadores, na palpação muscular, após um programa de calibração.

Orientador: Prof. Dr. Paulo César Rodrigues Conti

Orientado: Carlos Neanes Santos

\section{Informações aos Examinadores}

a) Os avaliadores deverão exercer uma pressão na palpação dos músculos de 1,5 a 1,8 kg, durante 2 segundos.

b) Cada examinador realizará uma palpação muscular digital para os músculos masséter e temporal e bidigital para o esternocleidomastóideo. Durante esse procedimento, os examinadores farão o registro da severidade da dor do paciente, numa ficha, utilizando os seguintes valores da palpação graduada:

$0=$ sem manifestação de dor

1 = manifestação de dor leve à palpação

2 = manifestação de dor moderada à palpação

$3=$ manifestação de dor severa à palpação

c) A palpação deverá ser feita com a mandíbula numa posição de repouso sem os dentes estarem em contato e lábios cerrados, ou seja, a palpação deverá ser feita no estado passivo, tendo o examinador o cuidado de colocar o paciente numa posição firme e relaxada.

\section{Informações e Localização dos Músculos}

\section{Temporal:}

- É um músculo grande, em forma aparente de leque, que tem sua origem na fossa temporal, na superfície lateral da cabeça. O músculo é formado por três feixes de fibras com diferentes direções: os do feixe anterior, que são verticais, feixe médio: oblíquos, e os posteriores, quase horizontais. Sua inserção se localiza no processo coronóide da mandíbula.

Local temporal anterior: $30 \mathrm{~mm}$ posterior ao ponto mais lateral sobre o limite da órbita e $15 \mathrm{~mm}$ acima da extremidade superior do arco zigomático.

Temporal médio: $60 \mathrm{~mm}$ ao longo de uma linha vertical desenhado perpendicular a uma linha do canto do tragus ao meio do meato auditivo externo.

Temporal posterior: localizado a $40 \mathrm{~mm}$ mais para posterior do ponto anteriormente marcado para temporal médio. 


\section{Masseter:}

- É um músculo formado por um feixe superficial e outro profundo. Origina-se no arco zigomático, estendendo-se para baixo até a borda inferior do ramo da mandíbula e parte do corpo. Sua inserção é no ângulo da mandíbula.

Masseter profundo: o paciente é solicitado a apertar e relaxar para identificar o bordo posterior do masseter superficial, onde uma pequena depressão pode ser sentida. O local é encontrado entre essa depressão e a ATM.

\section{Masseter superficial:}

ORIGEM: o paciente é solicitado a apertar e relaxar para identificar o bordo posterior, anterior e superior e então, a palpação será realizada na altura da face látero-inferior do arco zigomático.

CORPO: localizado entre a sua origem e inserção. O local da palpação será bem no meio do trajeto.

INSERÇÃO: o paciente também é solicitado a apertar e relaxar para identificar o bordo posterior e anterior, que está localizado entre o ângulo da mandíbula e a metade da parte lateral da mandíbula, e o local da palpação será feita na superfície lateral externa do ângulo da mandíbula.

\section{Esternocleidomastóideo:}

- Tem sua origem no osso esterno e clavícula e sua inserção no processo mastóide do osso temporal. O paciente vai ser solicitado a executar um movimento de rotação e flexão para localização do feixe do lado oposto. A palpação vai ser exatamente no meio do trajeto, próximo a sua origem e a sua inserção. 
4.1.2.3 Ficha C (utilizada pelos examinadores durante o exame dos indivíduos)

\section{Composta por:}

a) identificação do examinador e do paciente

b) anotação do período de avaliação: inicial, intermediária e final

c) tabela contendo os músculos, separando-os pelo lado esquerdo e direito com o propósito de fazer medição de dor utilizando para isso, a escala ordinal de 0 a 3 , onde 0 representava sem dor, 1 - desconforto à dor, 2 - dor moderada e 3 - dor severa, representada pelo movimento da pálpebra e desvio da cabeça a menor palpação. 


\section{UNIVERSIDADE DE SÃO PAULO}

\section{Faculdade de Odontologia de Bauru}

Pesquisa: Avaliação da reprodutibilidade interexaminadores, na palpação muscular, após um programa de calibração.

Orientador: Prof. Dr. Paulo César Rodrigues Conti

Orientado: Carlos Neanes Santos

Nome (paciente):

Data:

Examinador:

inicial

Avaliação:

intermediária

final

Exame Muscular

\begin{tabular}{|l|l|l|l|l|}
\hline & \multicolumn{1}{|c|}{ Direito } & \multicolumn{2}{|c|}{ Esquerdo } \\
\hline Masseter Profundo & & & \\
\hline Masseter Superficial (origem) & & & \\
\hline Masseter Superficial (corpo) & & & \\
\hline Masseter Superficial (inserção) & & & \\
\hline Temporal Anterior & & & & \\
\hline Temporal Médio & & & & \\
\hline Temporal Posterior & & & & \\
\hline Esternocleidomastóideo & & & & \\
\hline
\end{tabular}


4.1.2.4 Ficha $D$ (direcionada para o paciente para medição da dor, usada sempre antes do início de cada sessão de palpação)

Composta por:

a) identificação do paciente

b) escala de análise visual de dor (EAV), formada por um traço horizontal de $100 \mathrm{~mm}$, onde em seu extremo esquerdo lia-se "sem dor" e no direito " pior dor imaginável", na qual o paciente assinalava com um traço vertical a posição que melhor indicava o grau de dor sentida nesse momento. 


\section{UNIVERSIDADE DE SÃO PAULO \\ Faculdade de Odontologia de Bauru}

Pesquisa: Avaliação da reprodutibilidade interexaminadores, na palpação muscular, após um programa de calibração.

Orientador: Prof. Dr. Paulo César Rodrigues Conti

Orientado: Carlos Neanes Santos

Nome:

Data:

Avaliação:

\section{Escala de Análise Visual}

Indique a média de seu nível de dor nesse momento, marcando com uma linha vertical a escala abaixo. A extremidade esquerda indica ausência total de dor e a extremidade direita indica a pior dor imaginável.

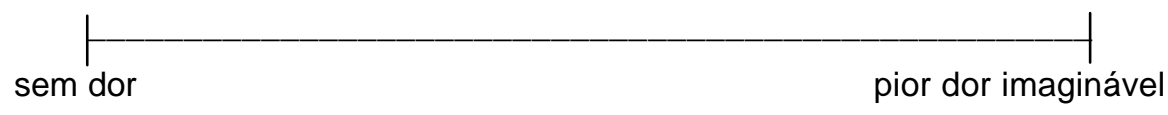




\subsubsection{Examinadores}

a) O grupo que foi treinado e realizou as palpações foi composto por 4 cirurgiõesdentistas, alunos de pós-graduação em Reabilitação Oral, em nível de Mestrado, da FOB-USP.

\subsection{Métodos}

\subsubsection{Treinamento e calibração dos examinadores}

Três semanas anteriormente ao estudo, cada examinador recebeu um protocolo escrito (Ficha B) contendo instruções a serem seguidas durante os exames. A localização precisa dos músculos e a pressão a ser exercida durante a palpação, faziam parte dessa ficha.

Duas semanas antes do início da pesquisa, os examinadores foram treinados a localizar e realizar a palpação dos músculos. Para tal, foi feita uma demonstração da localização dos músculos pelo coordenador, como também da força exercida durante a palpação. Essa demonstração foi realizada nos 4 examinadores, de maneira que eles pudessem sentir a pressão desejada pelo orientador da pesquisa. Durante essa demonstração, foi utilizada uma palpação muscular digital bilateral, usando apenas a extremidade do dedo indicador, com uma força em torno de 1,5 a 1,8kg, com 2 segundos de duração para os músculos masséter e temporal e uma palpação bidigital (dois dedos) para o músculo esternocleidomastóideo. Durante esse procedimento, a resposta do paciente ou reação à palpação era avaliada por uma escala ordinal de 0 a 3 , onde 0 representava sem dor, 1 - desconforto à dor (dor leve), 2 - dor moderada e 3 - dor severa, com resposta palpebral e/ou retirada da cabeça, evitando a palpação. 
Os examinadores também foram orientados a manter o paciente relaxado durante a palpação, já que indica-se uma posição de repouso mandibular sem os dentes estarem em contato.

O procedimento de calibração foi auxiliado por um algômetro, com a finalidade de padronização da pressão exercida. O treinamento foi realizado até que os examinadores chegassem a uma avaliação concordante em relação à localização e pressão exercida nos diversos músculos.

\subsubsection{Procedimento do exame}

Antes de cada sessão de exame e palpação, os pacientes foram orientados pelo coordenador do projeto a seguirem cuidadosamente as instruções do examinador, ou seja, relatar o nível de dor da maneira mais fácil possível e suprimir informações relacionadas a seu estado clínico, ou seja, não informar aos examinadores se eram pacientes com sintomas de DTM ou não. Além disso, o coordenador solicitou (sempre antes de cada exame), que cada paciente marcasse numa escala de análise visual (Ficha D) de 0 a $100 \mathrm{~mm}$, a posição que melhor indicasse o grau de dor naquele momento (somente para o grupo sintomático).

Em cada sessão foram avaliados 16 pacientes. Cada indivíduo foi examinado de acordo com uma seqüência pré-determinada, uma vez por cada examinador, sendo que o resultado das palpações não era divulgado entre os examinadores. Após 30 dias da realização deste primeiro exame, procedeu-se ao exame intermediário e após 45 dias a partir deste, o exame final, totalizando assim, 3 avaliações completas de cada indivíduo da amostra pelos 4 examinadores participantes da pesquisa.

Esses grupos de 16 pacientes, eram sempre compostos por 4 mulheres do grupo sintomático, 4 do grupo assintomático, 4 homens do grupo sintomático e 4 do grupo assintomático, avaliados em uma seqüência aleatória. 


\subsubsection{Análise Estatística}

Freqüência porcentual foi utilizada para descrever as diversas variáveis deste estudo, enquanto o teste de Concordância de Kendall avaliou a concordância interexaminadores em relação à análise da palpação muscular nos três exames realizados. Este teste estatístico foi realizado com o auxílio do software Statistica for Windows, versão 5.1, produzido pela Stat Soft Corporation, Tulsa - USA. 
5 RESULTADOS 


\section{RESULTADOS}

A amostra desse trabalho constou de 32 indivíduos divididos igualmente em 2 grupos: sintomáticos (16) e assintomáticos (16), com idade média de 31,3 anos, sendo de 28,3 anos para o grupo I (sintomático) e 34,3 anos para o grupo II (assintomático).

Considerando o sexo dos examinados, a amostra foi dividida eqüitativamente, ou seja, 16 indivíduos (8 homens e 8 mulheres) compuseram do grupo sintomático e 16 indivíduos (8 homens e 8 mulheres) participaram do grupo assintomático.

Em relação aos resultados obtidos com o relato subjetivo da dor anterior aos exames clínicos, através da escala de análise visual (EAV) não houve diferença estatisticamente significante $(\mathrm{P}<0.05)$ conforme demonstrado na Tabela 5.1. Tal parâmetro foi avaliado somente para o grupo sintomático.

TABELA 5.1 - Resultado médio das escalas de análise visual (EAV) durante as três avaliações.

\begin{tabular}{ccc}
\hline \hline ANÁLISE VISUAL & AVALIAÇÃO MÉDIA & DESVIO-PADRÃO \\
\hline \hline INICIAL & 5.43 & 2.63 \\
INTERMEDIÁRIA & 5.31 & 2.86 \\
FINAL & 5.31 & 2.74 \\
\hline \hline
\end{tabular}

Nessa Tabela, observa-se que o relato subjetivo de dor do paciente não foi alterado durante as três avaliações realizadas, mantendo uma média bastante semelhante nos três períodos de avaliação. 
Quando avaliada pelo teste de KENDALL, a concordância entre os 4 examinadores durante as três sessões de exame para cada músculo individualmente está representada na Tabela 5.2 e Figura 5.1. Observe o alto grau de concordância média, considerando-se que a escala do teste varia entre 0 e 1.

TABELA 5.2 - Valores médios do Teste de Kendall para os músculos nas três sessões de exame $(p<0.05)$

\begin{tabular}{lc}
\hline \hline \multicolumn{1}{c}{ MÚSCULOS } & MÉDIA \\
\hline \hline Masseter Profundo Direito (MPD) & 0.73 \\
Masseter Profundo Esquerdo (MPE) & 0.76 \\
Masseter Superficial Origem Direito (MSOD) & 0.60 \\
Masseter Superficial Origem Esquerdo (MSOE) & 0.63 \\
Masseter Superficial Corpo Direito (MSCD) & 0.70 \\
Masseter Superficial Corpo Esquerdo (MSCE) & 0.74 \\
Masseter Superficial Inserção Direito (MSID) & 0.65 \\
Masseter Superficial Inserção Esquerdo (MSIE) & 0.69 \\
Temporal Anterior Direito (TAD) & 0.64 \\
Temporal Anterior Esquerdo (TAE) & 0.74 \\
Temporal Médio Direito (TMD) & 0.56 \\
Temporal Médio Esquerdo (TME) & 0.64 \\
Temporal Posterior Direito (TPD) & 0.65 \\
Temporal Posterior Esquerdo (TPE) & 0.74 \\
Esternocleidomastoideo Superior Direito (ESD) & 0.79 \\
Esternocleidomastoideo Superior Esquerdo (ESE) & 0.77 \\
Esternocleidomastoideo Médio Direito (EMD) & 0.84 \\
Esternocleidomastoideo Médio Esquerdo (EME) & 0.80 \\
Esternocleidomastoideo Inferior Direito (EID) & 0.74 \\
Esternocleidomastoideo Inferior Esquerdo (EIE) & 0.75 \\
\hline \hline
\end{tabular}




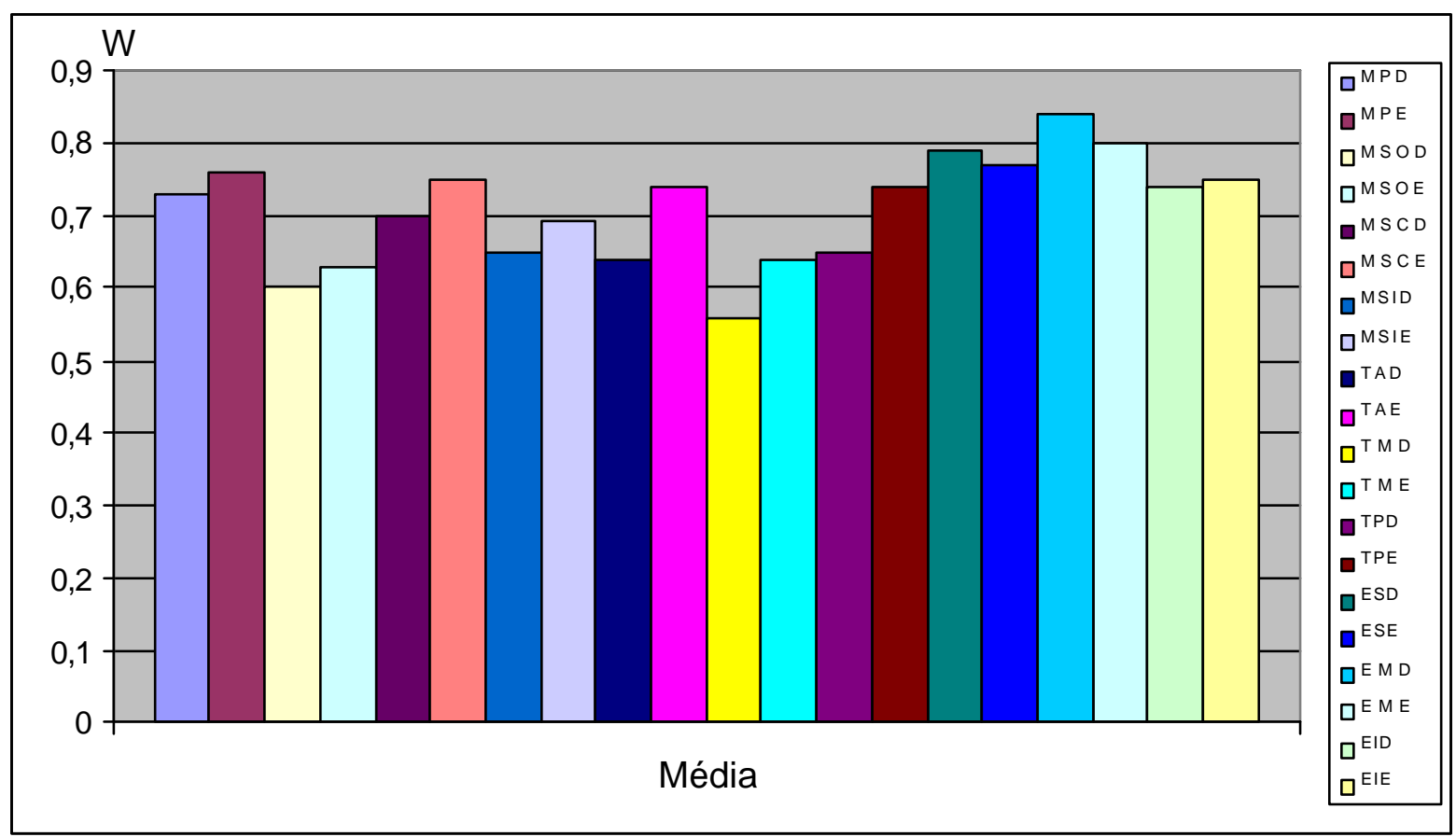

FIGURA 5.1 - Valores de concordância interexaminadores para os diversos músculos investigados nas três sessões de exame.

Nota-se que a melhor concordância entre os examinadores foi em relação ao músculo Esternocleidomastoideo Médio Direito $(0,84)$ e o pior resultado foi observado para o músculo Temporal Médio Direito, com valor de $\mathrm{KENDALL}=0,56$.

Portanto, os músculos onde foram observados uma maior concordância entre os examinadores foram: Esternocleidomatoideo Médio Direito $(0,84)$, Esternocleidomastoideo Médio Esquerdo (0,80), Esternocleidomastoideo Superior Direito $(0,79)$ e Esternocleidomastoideo Superior Esquerdo $(0,77)$, enquanto os músculos com uma menor concordância foram o Temporal Médio Direito $(0,56)$, 0 Masséter Superficial Origem Direito $(0,60)$ e o Masséter Superficial Origem Esquerdo $(0,63)$. 
Ao comparar-se individualmente cada músculo durante as três sessões, observa-se que o fator tempo também não foi um ítem de diferença na concordância interexaminadores. A Tabela 5.3 e a Figura 5.2 ilustram esses achados para o músculo Masséter profundo.

TABELA 5.3 - Valores de concordância (W) para o exame do músculo Masséter Profundo Direito e Esquerdo $(p<0.05)$

\begin{tabular}{c|ccc}
\hline MÚSCULO & INICIAL & INTERMEDIÁRIO & FINAL \\
\hline \hline MPD & 0,79 & 0,69 & 0,71 \\
MPE & 0,82 & 0,70 & 0,76 \\
\hline \hline
\end{tabular}

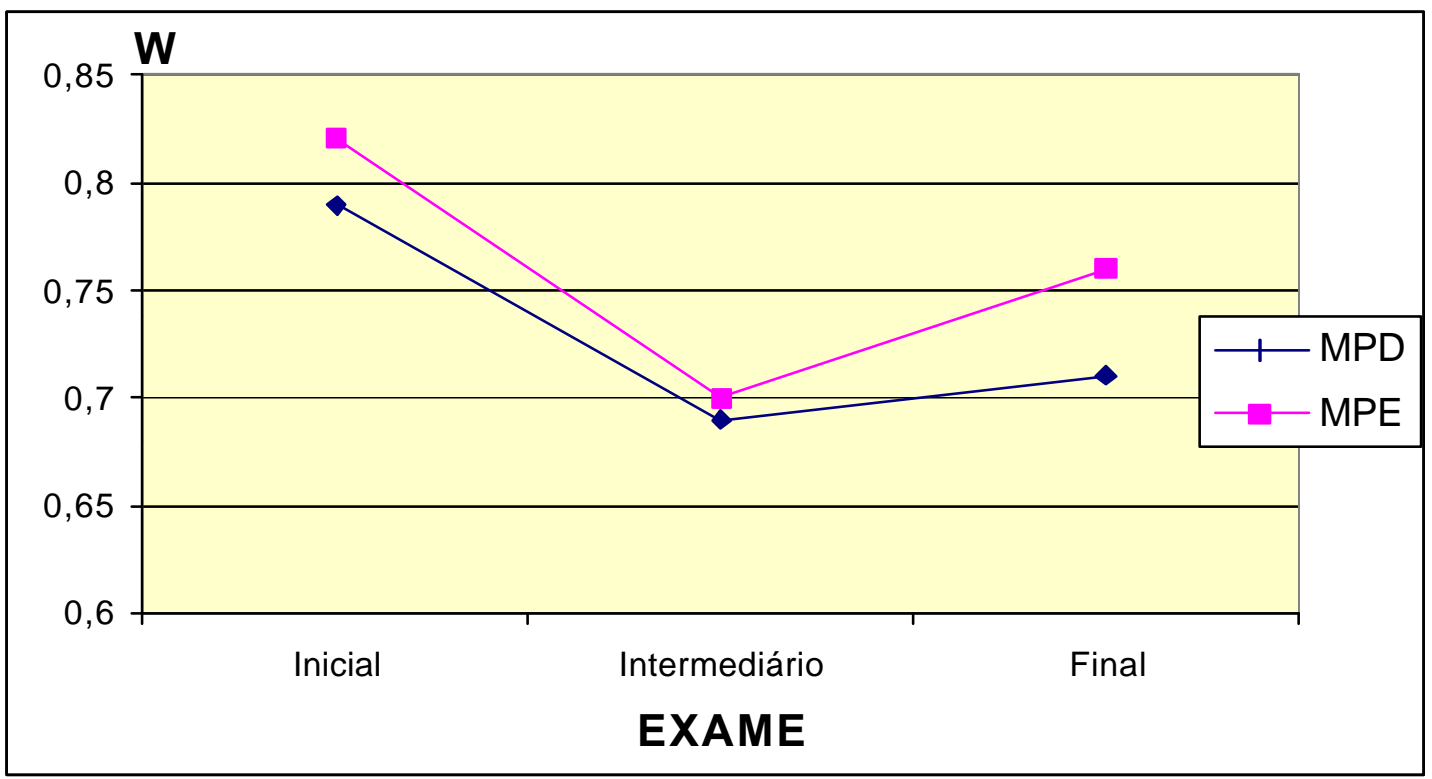

FIGURA 5.2 - Concordância interexaminadores para o músculo Masséter Profundo nos três exames realizados 
A Tabela 5.4 e Figura 5.3 mostram os valores de concordância para o músculo Masséter Superficial. Observe os valores mais baixos obtidos para a origem desse músculo no lado direito e esquerdo, principalmente durante a avaliação intermediária com um índice de 0.39 e 0.56 , respectivamente.

TABELA 5.4 - Valores de concordância (W) para o músculo Masséter Superficial: origem (D e E), corpo (D e E), inserção (D e E) $(p<0.05)$

\begin{tabular}{c|ccc}
\hline \hline MÚSCULO & INICIAL & INTERMEDIÁRIO & FINAL \\
\hline \hline MSOD & & & \\
MSOE & 0.73 & 0.39 & 0.69 \\
MSCD & 0.66 & 0.56 & 0.69 \\
MSCE & 0.71 & 0.67 & 0.74 \\
MSID & 0.80 & 0.75 & 0.69 \\
MSIE & 0.61 & 0.66 & 0.70 \\
\hline \hline
\end{tabular}

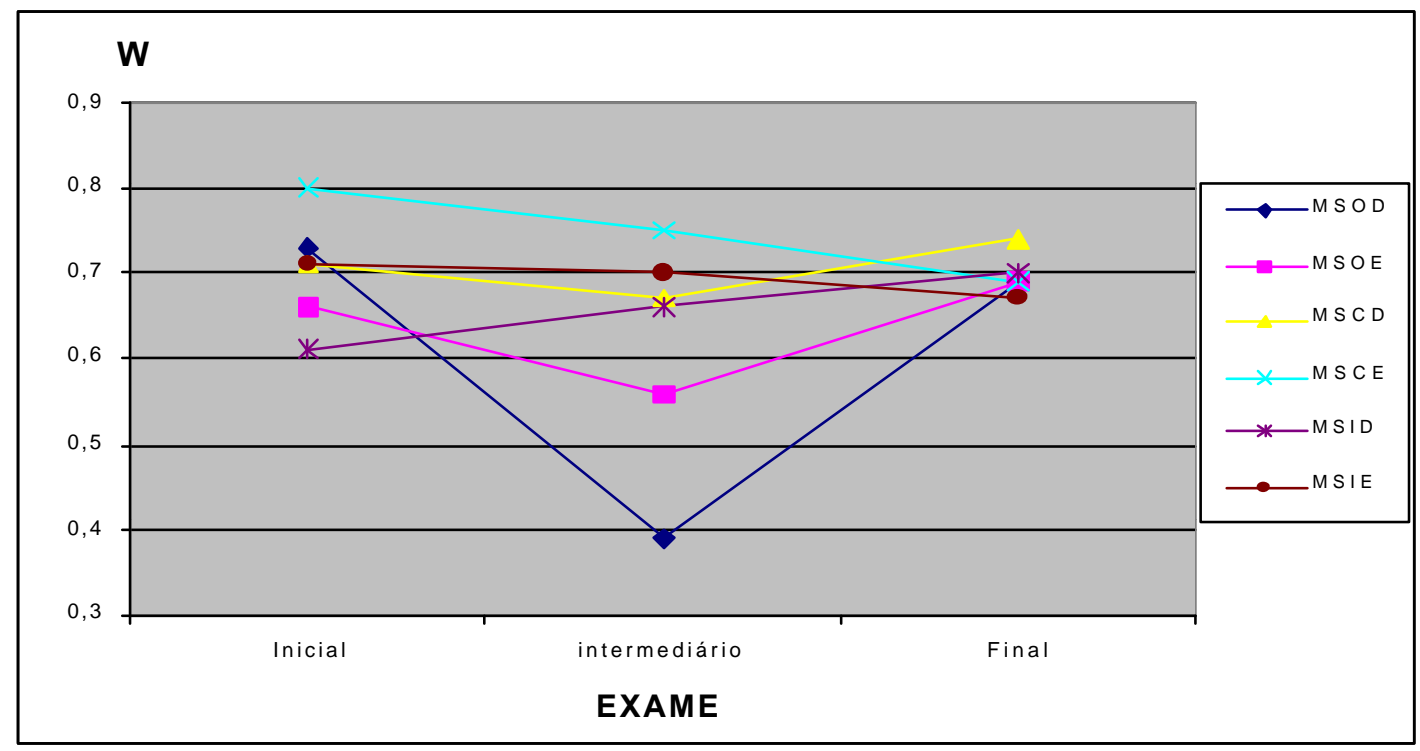

FIGURA 5.3 - Concordância interexaminadores para o músculo Masséter Superficial nos três exames realizados 
Os valores de concordância (W) para o músculo Temporal nos diferentes exames estão descritos na Tabela 5.5 e Figura 5.4. Observe os menores valores obtidos para o músculo Temporal Médio Direito, principalmente na avaliação intermediária e final.

TABELA 5.5 - Valores de concordância (W) para o músculo Temporal: Anterior ( $D$ e E); Médio ( $D$ e E) e Posterior ( $D$ e E) $(p<0.05)$

\begin{tabular}{c|ccc}
\hline MÚSCULO & INICIAL & INTERMEDIÁRIO & FINAL \\
\hline \hline TAD & & & \\
TAE & 0.56 & 0.62 & 0.74 \\
TMD & 0.73 & 0.73 & 0.77 \\
TME & 0.64 & 0.57 & 0.47 \\
TPD & 0.61 & 0.63 & 0.69 \\
TPE & 0.66 & 0.62 & 0.68 \\
\hline \hline
\end{tabular}

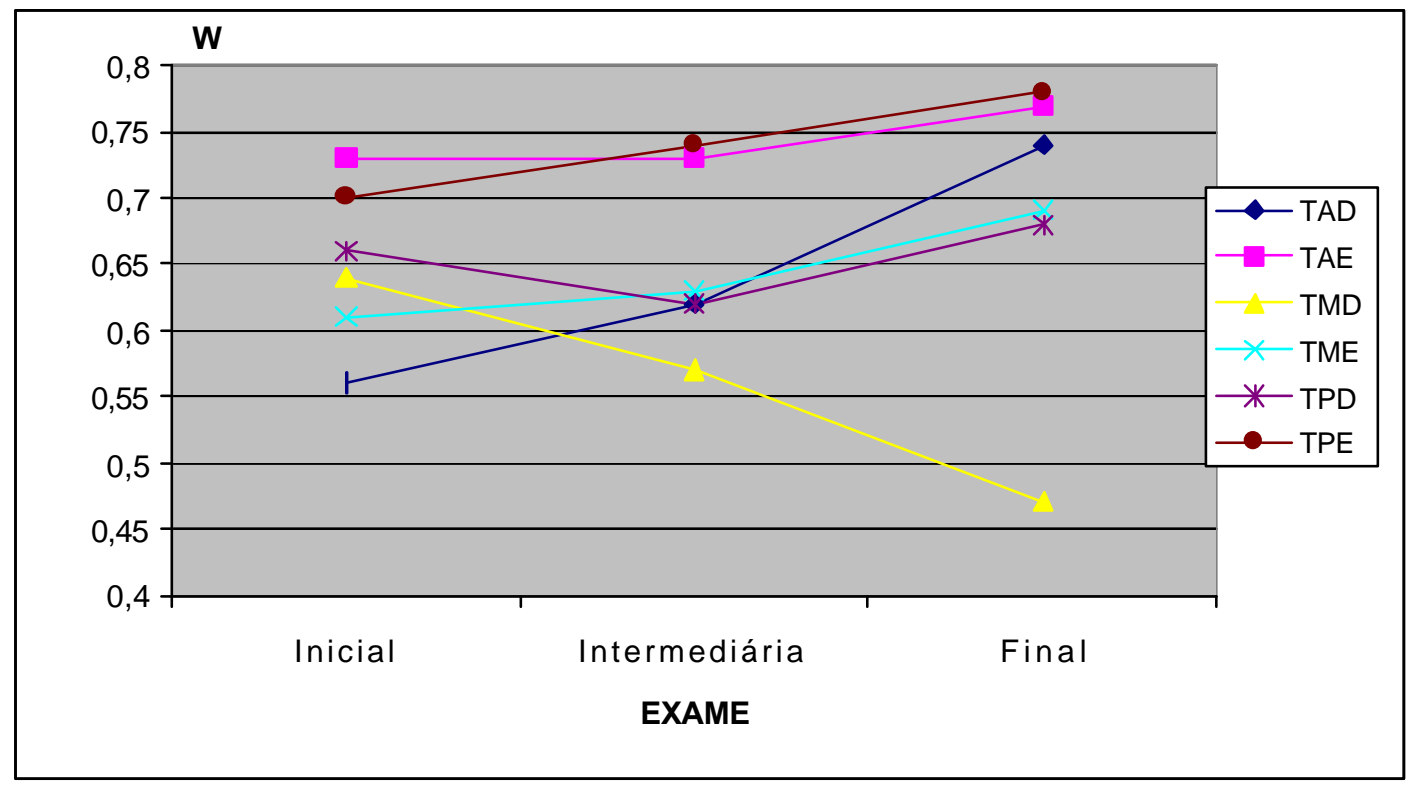

FIGURA 5.4 - Concordância interexaminadores para o músculo Temporal nos três exames realizados 
Já em relação ao músculo Esternocleidomastoideo, observaram-se os valores de concordância mais elevados, obtendo-se, também, pequenas variações entre os exames, como observado na Tabela 5.6 e Figura 5.5.

TABELA 5.6 - Valores de concordância (W) para 0 músculo Esternocleidomastoideo: Superior, Médio e Inferior $(p<0.05)$

\begin{tabular}{l|ccc}
\hline MÚSCULO & INICIAL & INTERMEDIÁRIO & FINAL \\
\hline \hline ESD & & & \\
ESE & 0.83 & 0.80 & 0.76 \\
EMD & 0.74 & 0.84 & 0.73 \\
EME & 0.83 & 0.89 & 0.81 \\
EID & 0.74 & 0.85 & 0.81 \\
EIE & 0.70 & 0.80 & 0.73 \\
\hline \hline
\end{tabular}

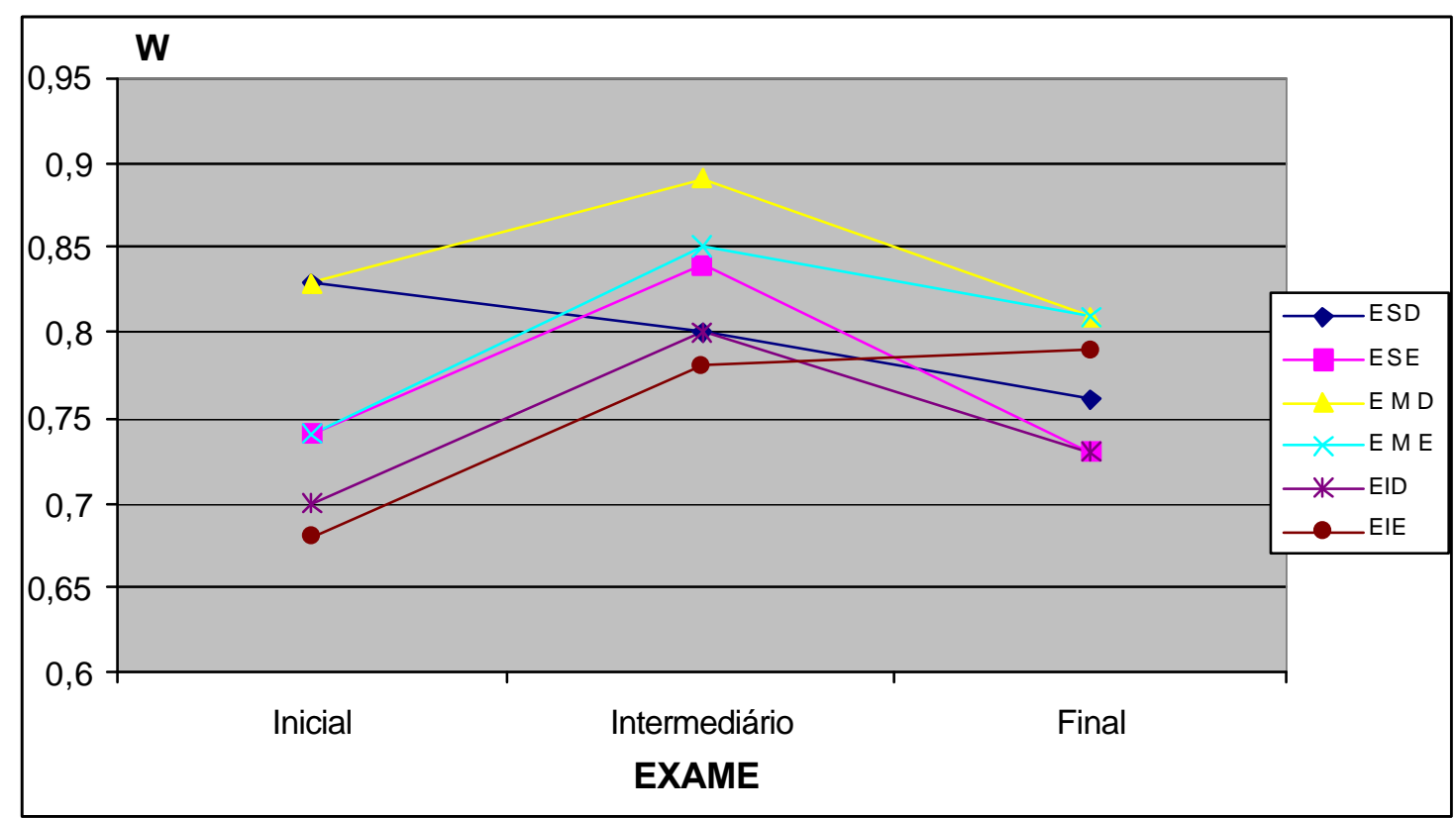

FIGURA 5.5 - Concordância interexaminadores para 0 músculo Esternocleidomastoideo nos três exames realizados 
Com o objetivo de verificar a concordância interexaminadores, variando-se o tempo da realização dos exames, o teste de concordância de KENDALL (W) foi, também, utilizado. Obteve-se a média entre os valores dos diversos músculos avaliados em cada tempo, sendo bastante próximos os valores de concordância, independentemente da época de avaliação, como observado na Tabela 5.7 e Figura 5.6.

TABELA 5.7 - Valores médios gerais do Teste de Kendall, registrados na concordância interexaminadores durante a realização dos três exames

\begin{tabular}{ccc}
\hline \hline EXAME & MÉDIA & DESVIO-PADRÃO \\
\hline \hline INICIAL & 0.71 & 0.07 \\
INTERMEDIÁRIO & 0.70 & 0.11 \\
FINAL & 0.72 & 0.07 \\
\hline \hline
\end{tabular}

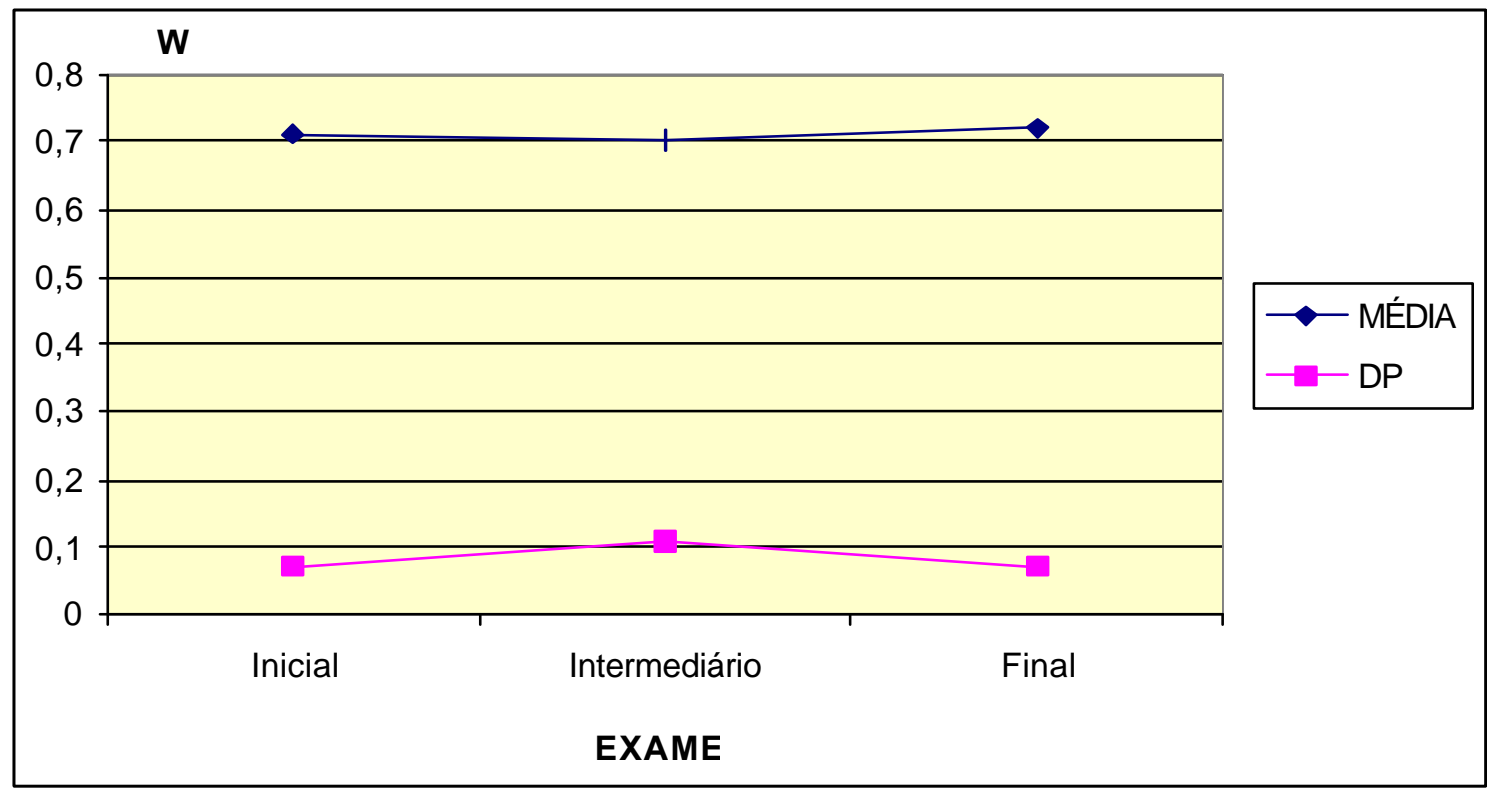

FIGURA 5.6 - Variação da concordância geral interexaminadores nos diferentes exames realizados 
Como a palpação foi realizada nos músculos em ambos os lados, tais resultados relativos aos lados direito e esquerdo são apresentados na Tabela 5.8, onde nota-se uma média de 0,72 no lado esquerdo, com desvio padrão de 0,05 e uma média de 0,69 para o lado direito, com desvio padrão de 0,08.

TABELA 5.8 - Valores de concordância (W) em relação aos lados direito e esquerdo $(p<0.05)$

\begin{tabular}{ccc}
\hline \hline LADO & MÉDIA & DESVIO-PADRÃO \\
\hline \hline ESQUERDO & 0.72 & 0.05 \\
DIREITO & 0.69 & 0.08 \\
\hline \hline
\end{tabular}

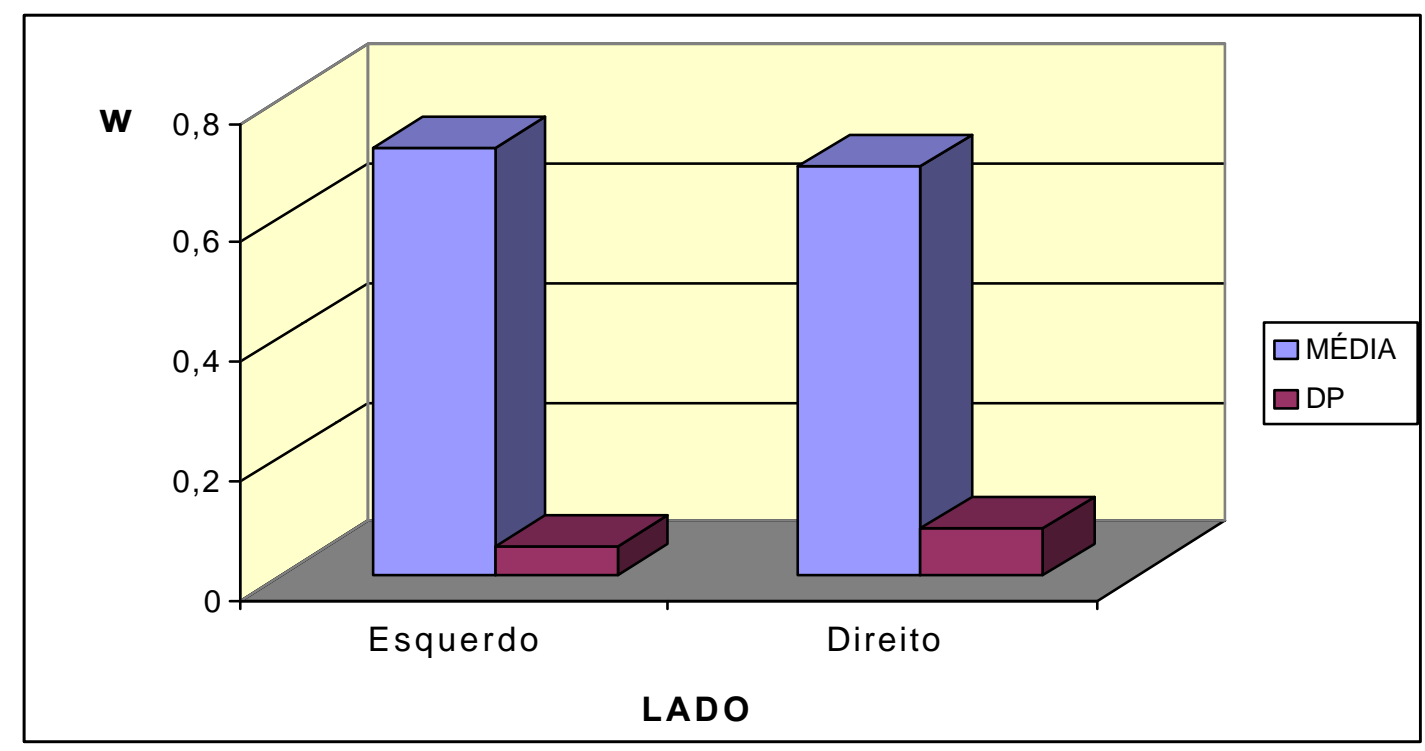

FIGURA 5.7 - Concordância interexaminadores em relação ao lado direito e esquerdo 
6 DISCUSSÃO 


\section{DISCUSSÃO}

Há um consenso de que a sensibilidade do músculo é um importante sinal clínico em pacientes portadores de dores miofasciais e disfunção músculoesqueléticas. A palpação digital muscular representa um teste, potencialmente relevante, que pode ajudar a diferenciar pacientes sintomáticos e assintomáticos de DTM, quando combinados com outros exames físicos e história clínica. É importante ressaltar que o exame físico deve sempre fazer parte dos procedimentos do cirurgiãodentista, com a finalidade de se confirmar os sintomas relatados.

Existe muita controvérsia e questões não resolvidas concernentes à utilidade da sensibilidade do músculo elicitada por palpação digital como um auxílio diagnóstico e um critério de inclusão para os diversos subgrupos que compõem as DTM. Isso é devido, particularmente, aos vários resultados contraditórios de estudos de confiabilidade entre os examinadores.

A literatura a respeito da confiabilidade interexaminadores na avaliação clínica da dor orofacial é bastante ampla. Estudos anteriores ${ }^{5,25,48,99}$ enfocaram a confiabilidade interexaminadores na avaliação da cárie ${ }^{48}$, da condição do sistema mastigatório $^{5}$, dos sinais e sintomas da doença periodontal ${ }^{25}$ e de exames radiográficos $^{99}$. Nesses estudos radiográficos, de cárie e doença periodontal, a padronização dos examinadores lidou com dados relativamente objetivos, tais como profundidade da bolsa, perda de osso e presença ou ausência de cárie. Em contraste, a padronização da palpação muscular é baseada em dados menos objetivos. A interpretação das reações dos indivíduos pode ser dependente do treinamento e experiência do examinador e da técnica de palpação. Além disso, o estado emocional, aspectos de ordem biológica e psicológica, o grau de percepção do 
paciente, a intensidade da força aplicada e os sítios de aplicação são fatores que podem influenciar a validade ou confiabilidade do método de palpação.

Parece uma unanimidade na literatura ${ }^{5,20,27,33,34,90,92}$ que, para assegurar a confiabilidade dos dados coletados, a padronização do exame é essencial, sendo a calibração interexaminadores uma das maneiras de se obter essa uniformidade nos procedimentos.

Vários estudos $5,18,20,27,33,34,53,90,92$ têm sido desenvolvidos com a finalidade de se avaliar a confiabilidade e reprodutibilidade dos métodos de palpação em função do grau de concordância inter e intra-examinadores, porém os resultados encontrados são contraditórios. Alguns investigadores ${ }^{5,18,20,27,33,34,62,92,101}$ relatam boa ou excelente concordância inter e intra-examinadores, enquanto outros ${ }^{13,21,52,53,90,106}$ encontram um alto grau de variabilidade.

A análise dos fatores que levaram a essa variabilidade, ou seja, a participação do relato do indivíduo, o método do examinador ou a natureza instável dos sintomas, ainda continuam sem resposta na literatura.

Em relação ao relato dos indivíduos, os resultados são bastantes contraditórios, pois, geralmente, a confiabilidade da sensibilidade muscular e da articulação é julgada pela consistência da resposta do paciente, ou reação à palpação, ou seja, os pacientes podem ser solicitados a diferenciar entre pressão e dor $^{1,18,28}$, indicar a dor associada à palpação assinalando numa escala que vai de 0 a $100^{7,33,34,43,57,58,104}$ ou avaliar a dor através do uso de várias escalas descritivas verbais, como a escala ordinal de 0 a $3^{18,20,33,57}, 0$ a $5^{22,34}$ e 0 a $2^{61}$.

Como observado, existe um grande número de meios de análise da resposta à dor na literatura e poucos estudos para avaliar sua real eficácia.

ATWOOD et al. ${ }^{1}$, por exemplo, compararam a escala categórica de dois pontos com uma escala de 4 pontos em relação à capacidade de expressar alterações na sensibilidade do músculo e da ATM. Obtiveram, como resultado, que a escala de 4 pontos refletiu uma maior diminuição na sensibilidade do músculo e da ATM nas 6 semanas seguintes aos exames, quando comparada à escala categórica de 2 pontos, 
apesar do alto grau de correlação existente entre as duas escalas na obtenção dos resultados. De acordo com os autores, a escala de 2 pontos é simples e minimiza a chance de ocorrerem erros de interpretação, enquanto a escala de 4 pontos exige do examinador uma interpretação da resposta do paciente à palpação, o que poderia aumentar a variabilidade nos resultados. Já LE RESHE; BURGESS; DWORKIN ${ }^{57}$ avaliaram a confiabilidade da escala da análise visual e da escala descritiva verbal na medição da dor das DTM e concluíram que ambas as escalas não são ferramentas confiáveis para a quantificação da dor na palpação da DTM. Apesar dos diferentes resultados, ambos concordaram que o uso dessas medidas para propósitos de pesquisa ou para a prática clínica ainda permanecem como sendo de grande valor. Além disso, os autores ainda concordaram que em situações clínicas, a avaliação da dor induzida pela palpação é geralmente registrada por uma escala categórica de 4 pontos $(0-3)$ e que apesar desta ser útil para propósitos clínicos, não permite registrar pequenas diferenças na dor. Já a escala de análise visual fornece dados da dor, na forma de uma variável contínua, sendo sensível a pequenas mudanças na dor.

A mesma opinião possuem CHAPMAN et al. ${ }^{7}$, acrescentando, ainda, que a escala de análise visual poderia ser utilizada em indivíduos com pouca instrução.

Neste trabalho, foram utilizadas as duas escalas: escala de análise visual, usada para verificar a intensidade da dor relatada pelos pacientes previamente às 3 avaliações realizadas, e a escala descritiva verbal de 4 pontos, contendo a seguinte escala: 0 (sem dor), 1 (desconforto à dor), 2 (dor moderada) e 3 (dor severa), a qual tem sido bastante utilizada ${ }^{1,20,33,57}$, onde o paciente é questionado sobre a sensação de dor após cada procedimento de palpação. É bom salientar que grande parte das respostas obtidas pela utilização da escala de 4 pontos foi referente ao código 0 - sem dor ,apresentando um índice aproximado de $40-60 \%$ de todas as respostas coletadas, seguido pelo código 1- desconforto a dor, com $20-40 \%$, código 2 - dor moderada,10$25 \%$ e do código 3 - dor severa, $2-5 \%$.

Um outro fator de variabilidade entre os diversos trabalhos é a metodologia usada na palpação dos músculos, ou seja, que pressão os examinadores estariam 
usando e através de que método essa palpação estaria sendo realizada (manual ou com o uso do algômetro).

Sem uma padronização, a capacidade para comparar resultados da palpação entre diferentes estudos, fica difícil, principalmente diante de tamanha diversidade de técnicas e diferentes pressões relatadas na literatura ${ }^{1,19,33,34,38,44,49,98}$.

Talvez tenha sido LIBMAN ${ }^{59}$ o primeiro autor a avaliar a sensibilidade da dor em um paciente empregando, para isso, o dedo polegar contra o processo estilóide. Nessa época, os autores ainda não se preocupavam com a quantificação da sensibilidade muscular.

Mas foram GROSS; GALE ${ }^{38}$ um dos primeiros autores a descreverem um protocolo de treinamento e a sugerirem diretrizes operacionais a respeito de como usar os dedos e como conseguir uma quantidade de pressão ideal para aplicar na palpação dos músculos mastigatórios. Em seu estudo de prevalência, examinadores foram treinados para aplicarem 3 libras de pressão por 2 segundos (aproximadamente $1,4 \mathrm{~kg}$ ) durante a palpação dos músculos mastigatórios e dos aspectos lateral e posterior da ATM. Segundo os autores, essa pressão de 3 libras de pressão pareceu ser adequada, pois provou-se ser eficiente para elicitar uma resposta positiva nos pacientes com disfunção. Da mesma forma, não era exagerada para levar a uma resposta falso positiva em pacientes sem disfunção. Para chegar a essa medição, os autores utilizaram um tipo de sensor colocado ao redor da área do dedo, coberto por uma luva de borracha, o qual detectava a quantidade de pressão utilizada quando o paciente relatasse o início da dor.

Como observado na revisão de literatura ${ }^{1,19,33,34,38,44,45}$, existe uma grande variabilidade de opiniões a respeito da quantidade de pressão aplicada, tornando difíceis as comparações entre os estudos. Além disso, níveis de pressão aplicada são relatados em diferentes unidades de medida de força que, apesar de passíveis de conversão, dificultam o entendimento de leitura entre os diversos trabalhos. 0 presente trabalho utilizou uma pressão em torno de 1,5 a 1,8kg, concordando com os trabalhos de GOULET et al. ${ }^{34}$ e GOULET; CLARK; FLACK ${ }^{33}$, pois essa quantidade de pressão provou-se adequada para elicitar uma resposta positiva nos pacientes com 
DTM, sendo também suficiente o bastante para não fazer surgir uma resposta falsopositiva em indivíduos assintomáticos, ou seja, apresentaria especificidade e sensibilidade compatíveis.

Em relação ao tempo de aplicação, a grande maioria dos trabalhos ${ }^{19,27,33,34,38,79}$ recomenda que a palpação seja feita por 2 segundos, que correspondeu ao tempo utilizado na presente pesquisa.

Quanto ao método de aplicação há, também, uma grande diversidade de opiniões na literatura. Alguns ${ }^{5,13,18,20,21,27,33,34,52,53,62,90,101,106}$ preferem a palpação digital, outros $8,9,41,42,43,44,45,46,83,84,87,95$ preferem o uso de instrumento para medir a pressão, denominado algômetro. Embora seja a palpação um método clínico muito utilizado para avaliar sensibilidade à dor, é difícil quantificar seus achados. Por isso, instrumentos mecânicos, como o algômetro, foram desenvolvidos e aperfeiçoados na tentativa de se melhor quantificar a sensibilidade muscular através da medição do limiar de dor à pressão (LDP). Quando colocados junto à pele do paciente, esses aparelhos permitem a leitura da pressão exercida pelo examinador no momento em que o paciente expressa sua dor por simples manifestação verbal ou pela utilização de um interruptor acionado pelo paciente nesse momento.

Existe, também, variações para cada método, ou seja, na palpação digital alguns autores ${ }^{45,79}$ usam dois dedos (indicador e médio), outros ${ }^{33,38}$ usam três dedos (indicador, médio e anular), fazendo um movimento rotatório, de um lado para o outro, todos mantendo contato com o tecido e alternando a maior pressão de um dedo para outro, para maximizar a área de palpação. Já BOHL; KNAPP² utilizam a mesma técnica (3 dedos), porém de maneira diferente, ou seja, o dedo médio localiza a região da dor e o indicador e anular são usados para examinarem as regiões que estejam adjacentes à região primária da palpação, utilizando uma pressão suave, mas firme.

$\mathrm{Na}$ presente pesquisa, o método utilizado seguiu as orientações de OKESSON $^{79}$, que utiliza a superfície palmar do dedo indicador e o médio, fazendo uma pressão suave, porém firme de 2 segundos de duração. 
Apesar de ambas as técnicas de palpação terem o mesmo objetivo, ou seja, avaliar a sensibilidade muscular, HARDY;WOLFF;GOODELLI. ${ }^{39}$ e KEELE ${ }^{49}$ afirmaram que um método adequado de mensuração do limiar de dor teria que apresentar algumas características, como: mensurabilidade do estímulo com reprodutibilidade, controle adequado do limite de pressão, não causar danos ao tecido, e ser de fácil utilização. Segundo os autores, o uso da palpação digital oferece amplamente essas condições, com exceção da mensuração de dor, a qual foi plenamente alcançada com o uso do algômetro, fato este, contestado por GOULET et al. ${ }^{34}$, que considerou a palpação digital confiável, desde que precedida de programa de calibração e treinamento.

Na prática clínica, a palpação manual do músculo é o método mais comum e o mais aceito para examinar a sensibilidade muscular. $O$ uso do algômetro para medir os limiares de dor à pressão representa um meio de estudar a sensibilidade muscular de uma maneira mais objetiva do que a palpação manual, porém, dificuldades de popularização da técnica, assim como a necessidade de aquisição do aparelho limitam sua utilização de uma maneira mais ampla. Tendo isso em mente, ou seja, a aplicabilidade prática dos resultados, optou-se por utilizar a palpação manual no presente trabalho.

O algômetro foi utilizado apenas no processo de calibração dos examinadores para se determinar a quantidade de pressão ideal, na palpação dos músculos envolvidos na pesquisa.

Após discutidos os diversos métodos empregados na palpação e suas conseqüências na variabilidade dos resultados de confiabilidade interexaminadores, a natureza instável dos sintomas, a qual contribui bastante para tal variabilidade, também merece alguns comentários.

Existem vários trabalhos ${ }^{5,21,32,97,104}$ que relatam a flutuação cíclica dos sintomas, não só num curto espaço de tempo, como GOULET; CLARK; FLACK ${ }^{32}$, que verificaram a alternância de sintomas relatados pelos indivíduos durante exame da ATM, repetidos após 15 minutos, como em grande espaço de tempo como DWORKIN 
et al. ${ }^{21}$, que relataram uma oscilação de sintomas após investigação epidemiológica numa população, realizada 1 ano e 3 anos após a primeira coleta de dados.

Existe, ainda, um outro fator que poderia afetar a concordância interexaminadores, relacionado à interpretação de dor no Sistema Nervoso Central (SNC). A resposta à dor originada por qualquer estímulo nocivo pode sofrer alteração antes que chegue à córtex, isto é, o SNC tem a capacidade de alterar ou modular os impulsos nociceptivos antes que atinjam centros superiores para reconhecimento. Portanto, devido a várias formas de modulação de dor, a resposta do paciente a procedimentos de estímulo periférico (como a palpação) nem sempre corresponde exatamente à quantidade desse estímulo.

Segundo MERSKEY ${ }^{68}$, a dor é definida como uma experiência sensorial e emocional desagradável, associada a um dano tecidual real ou descrito como tal. De acordo com essa definição, ambos os componentes sensoriais e de sofrimento incluem uma variedade de influências psicológicas e são importantes para a manifestação total da percepção da dor. Hoje, aceita-se que a experiência da dor consiste de várias dimensões intrínsecas, incluindo aspectos sensoriais, cognitivos e afetivos. Todas essas dimensões interagem e afetam a resposta à dor nos diversos níveis.

De acordo com GOULET; CLARK; FLACK ${ }^{32}$, o estado emocional e a expectativa dos resultados podem também alterar a confiabilidade interexaminadores.

Portanto, baseados no relato de vários autores ${ }^{4,16,17,32,68,80}$, observa-se que a confiabilidade interexaminadores na avaliação da sensibilidade muscular pela palpação pode não só depender de um treinamento para calibração ideal como também de outros fatores associados à resposta do paciente ao estímulo periférico.

Neste trabalho, percebeu-se, de uma maneira geral, que o valor de concordância entre os quatro examinadores para os músculos analisados não variou com o tempo, sendo de $0.71,0.70$ e 0.72 nos exames inicial, intermediário e final, respectivamente. Essa concordância manteve-se constante em todos os músculos investigados, com algumas exceções como a origem do Masséter Superficial Direito 
(0.73, 0.39 e 0.69), o Temporal Médio Direito $(0.64,0.57$ e 0.47) e a origem do Masséter Superficial Esquerdo (0.66, 0.56 e 0.69). Portanto, em relação ao tempo, o índice de confiabilidade entre os examinadores foi mantido, apesar dos intervalos de 30 dias da realização do primeiro exame, e 45 dias para o terceiro exame. Essa manutenção também foi observada para o relato subjetivo de dor do paciente através da escala de análise visual, com uma média de 5.43 de avaliação inicial, 5.31 na avaliação intermediária e 5.31 na avaliação final demonstrando, também, uma constância dos sintomas clínicos para o grupo estudado, concordando com o trabalho de CARLSSON ${ }^{5}$, onde durante cinco semanas, os sintomas permaneceram constantes.

É importante distinguir entre dois tipos de mensuração de concordância: uma refere-se à consistência de cada examinador em executar a mesma tarefa repetidas vezes (intra-examinador) e a outra indica se essa mesma consistência existe entre examinadores quando fazendo observações da mesma variável (interexaminador).

No presente trabalho, apesar da não diferenciação estatística entre as escalas de análise visual nos três exames realizados ( $p>0.05$ ), a avaliação intraexaminadores não foi mensurada, devido à grande oscilação da variável "resposta à dor" e das análises de consistência de resultado em diferentes tempos (pelo mesmo examinador) poderiam ser altamente imprecisas. Os resultados obtidos na análise da confiabilidade interexaminadores, neste estudo demonstraram em função da homogeneidade dos valores atribuídos para cada examinador ser desnecessária a realização da análise intra-examinador.

Um outro aspecto a ser considerado é a comparação de um determinado teste com métodos eficientes já existentes.

De acordo com STOREY; RUGH ${ }^{93}$, para se testar a eficácia de um procedimento diagnóstico, este deverá ser comparado a um "gold standard", que são métodos de mensuração aceitos de um modo geral, tanto quanto possível, pela comunidade científica. 
Ainda segundo o mesmo autor ${ }^{93}$, o "gold standard" pode ser simplesmente a opinião clínica de alguns "experts" no assunto. É importante sabermos a probabilidade de que a doença esteja presente ou ausente quando um teste diagnóstico é tido como positivo ou negativo e isso tem sido bastante discutido no caso de palpação muscular.

Portanto, um teste diagnóstico tem que ter precisão, que é mensurada tanto pela habilidade de detectar doenças, quando se está presente (sensibilidade), quanto pela habilidade de excluir doenças (especificidade). De acordo com WIDMER ${ }^{105}$, o nível de sensibilidade e especificidade de um diagnóstico considerado aceitável para um teste depende da prevalência e gravidade da doença e da estimativa de erros devido ao mau diagnóstico. Ou seja, em razão de somente 4 a $7 \%$ da população geral procurarem por tratamento, e de que pacientes com DTM não sofrem risco de vida, baixos níveis de sensibilidade podem ser usados para essa disfunção. Em outras palavras, por causa do aspecto apenas moderado dos sintomas e ausência de risco de vida, pode-se aceitar baixos níveis de sensibilidade para detectar os pacientes com DTM. Por outro lado, o paciente assintomático, uma vez incorretamente diagnosticado como tendo a doença, poderia estar sujeito a um tratamento desnecessário e potencialmente danoso, levando a custos financeiros e humanos substanciais. Portanto, um teste de diagnóstico na área de DTM deve ter uma especificidade alta, pois um falso positivo poderia levar a procedimentos irreversíveis como cirurgia ou odontologia restauradora. A palpação do músculo pterigóideo lateral é um típico exemplo dessa baixa especificidade, não estando indicada nos dias atuais. Baseado nisso, não foi incluída no presente estudo.

FRICTON; SCHIFFMAN ${ }^{27}$ verificaram que a palpação intra-oral foi o método que obteve o menor índice de confiabilidade, devido a difícil acessibilidade do local, além de ser uma área normalmente sensível à palpação. Resultados semelhantes foram obtidos em outros artigos ${ }^{2,29}$ em que os autores afirmaram que a técnica de palpação nos músculos pterigóideo lateral e medial pode causar dor em indivíduos normais, caracterizando falsos positivos. 
Como observado até esse ponto de discussão, cuidados foram tomados em relação à metodologia empregada nessa pesquisa, métodos esse que concordam com literatura vigente.

Ao discutir-se, agora, os resultados das concordâncias, observa-se graus altamente aceitáveis para a área de saúde.

SMITH $^{90}$ encontrou maior concordância na análise de indivíduos sintomáticos, fato esse que, provavelmente, deve-se ao conhecimento da condição clínica por parte dos examinadores, que introduziram um componente tendencioso na avaliação dos sintomas do paciente, ou seja, os examinadores já esperavam que os pacientes possuíssem sinais e sintomas de DTM. Para evitar que alguma influência fosse introduzida, a amostra aqui empregada foi composta por 32 indivíduos (16 sintomáticos e 16 assintomáticos) onde a condição clínica dos pacientes permanecia totalmente desconhecida por parte dos examinadores. No trabalho de $\mathrm{SMITH}^{90}$, apesar do treinamento recebido antes dos exames, não houve concordância nas avaliações gerais, diferentemente do nosso trabalho que apresentou uma concordância altamente satisfatória.

Os resultados de concordância aqui obtidos (entre 0.56 e 0.84 ) são comparáveis aos de CARLSSON et al. ${ }^{5}$, STOCKSTILL; GROSS; MACCALL ${ }^{92}$, GOULET; CLARK; FLACK ${ }^{33}$ e GOULET et al. ${ }^{34}$ em relação à palpação manual precedida por programas de calibração. Esse fato é importante, pois nesse trabalho foi utilizada uma escala de resposta do paciente de 4 pontos, o que poderia dificultar 0 julgamento dos examinadores.

Também não foram encontradas diferenças entre os diferentes exames, ou seja, a calibração foi eficiente, mesmo após 45 dias. Esse fato já foi objeto de discussão.

Alguns trabalhos ${ }^{5,21,32,97,104}$ ressaltam a grande importância da flutuação cíclica dos sinais, responsável pela variabilidade nos resultados de concordância entre examinadores, além da necessidade de se ter um grupo controle na amostra para uma melhor interpretação dos resultados. 
Os resultados observados no trabalho de CARLSSON ${ }^{5}$, concordam com os dados aqui obtidos em relação à concordância interexaminadores. Foi encontrada uma confiabilidade de 80 a $100 \%$ nos dois grupos investigados contra um índice de concordância médio de 0.71 no presente trabalho, índice esse semelhante ao de GOULET; CLARK; FLACK ${ }^{33}$. Contrastando com esses resultados, encontram-se os trabalhos de KOPP52; KOPP; WENNEBERG ${ }^{53}$, DAHLSTRÖN et al. ${ }^{13}$, que obtiveram uma pobre concordância interexaminadores.

A confiabilidade nitra e interexaminador obtida no trabalho de DUINKERKE ${ }^{18}$ esteve entre 0.73 e 0.95 , acima da média de concordância obtida nessa pesquisa.

Esses altos valores obtidos por DUINKERKE ${ }^{18}$, talvez seja resultado do curto intervalo de tempo entre os exames (poucos dias) e pelo uso de uma escala de 2 pontos (dolorido ou não) na resposta à palpação. Além disso, os examinadores fizeram suas avaliações parelhados, enquanto neste trabalho, as três avaliações foram feitas por 4 examinadores, nos intervalos de tempo após o primeiro exame, de 30 e 45 dias, utilizando uma escala de 4 pontos no relato à dor .

O alto índice de 0.95 de concordância na avaliação interexaminadores também obtido por FRICTON; SCHIFFMAN ${ }^{27}$ talvez tenha ocorrido porque os autores usaram, em sua amostra, apenas pacientes com sinais e sintomas de DTM, onde a probabilidade de aumento da concordância é muito grande, pelo fato dos examinadores já conhecerem o estado clínico dos mesmos, ou seja, pela ausência de "verdadeiros negativos". Essa influência não houve em nosso trabalho pelo fato da amostra conter 2 grupos, sintomáticos e assintomáticos, e os examinadores não conhecerem a situação clínica dos pacientes, diminuindo, assim, a influência de direcionamento do julgamento.

Fato semelhante também pode ser observado nos trabalhos de CARLSSON et al..$^{5}$ e DUINKERKE ${ }^{18}$, onde a amostra era composta, agora, somente por assintomáticos, ou seja, os examinadores sabiam que estariam examinando indivíduos sem sintomas, aumentando, portanto, a probabilidade de concordância (ausência de sensibilidade dolorosa). 
Para se obter bons resultados, parece fundamental a realização de procedimentos de calibração. Esse fato é bem ilustrado no trabalho de STOCKSTILL; GROSS; MCCALL ${ }^{92}$, onde a concordância interexaminadores mostrou-se progressivamente melhor após cada treinamento executado com os examinadores. $\mathrm{Na}$ primeira avaliação feita por dois examinadores, o KAPPA de 0.37 (considerado concordância "regular") passou para 0.70 (concordância "satisfatória") na segunda avaliação feita uma semana após outro programa de calibração e diminuiu para 0.63 (mantendo ainda concordância "aceitável") na terceira avaliação, após 5 semanas sem padronização adicional. Resultados semelhantes foram obtidos neste trabalho na segunda avaliação, com uma média geral de 0.70 na concordância interexaminadores. Os autores, então, concluíram que após cada calibração, existe um aumento da concordância entre os examinadores, que pode ser mantida por um período mínimo de 5 semanas, onde seria necessário um novo treinamento. Também DWORKIN; LE RESCHE; DE ROVEN ${ }^{20}$ otimizaram seus resultados a partir da calibração dos examinadores, de 0,47 para 0,65 para os músculos extra-orais e de 0,27 para 0,61 para os músculos intra-orais, provando, portanto, a necessidade de um perfeito treinamento para calibração dos examinadores.

No trabalho de CARLSSON ${ }^{5}$, os examinadores apenas executaram os mesmos procedimentos em um grupo restrito, anterior aos exames, e discutiram entre si os resultados obtidos. Já em DUINKERKE ${ }^{18}$, estudantes de odontologia foram treinados por uma hora para a técnica de palpação em indivíduos que não foram incluídos na investigação, enquanto que no trabalho de $\operatorname{DAHLTRÖN}^{13}$, os oito examinadores foram treinados por um experiente dentista. Esse treinamento consistiu de um vídeo de instrução de 19 minutos, uma demonstração clínica da técnica de exame por 40 minutos, prática clínica executada em pacientes e discussão do protocolo clínico. Os trabalhos de KOPP; WENNBERG ${ }^{53}$ e DUINKERKE et al. ${ }^{18}$, não realizaram padronização entre os examinadores.

Neste trabalho não houve uma calibração adicional, após o início dos exames, porém, os bons resultados obtidos se explicam pela eficiência do processo de calibração, que incluiu desde a explicação minuciosa com entrega de protocolo 
escrito contendo todas as instruções a serem seguidas durante o exame, explicações referentes a localização precisa dos músculos e pressão a ser exercida durante a palpação, além de demonstração clínica, realizada pelo orientador da pesquisa e ainda a realização de treinamento efetuado entre os próprios examinadores.

Outro parâmetro a ser discutido é o tipo de análise dos resultados aplicado nos diversos estudos. De acordo com DWORKIN; LE RESCHE; DE ROUEN ${ }^{20}$, o teste estatístico recomendado para avaliar a confiabilidade dos examinadores parelhados para dados medidos por escalas que contêm respostas descontínuas (sim, não, nenhuma, moderada, severa) seria o teste de KAPPA $(K)$. Concordando com essa afirmação, encontra-se o trabalho de $\mathrm{HUNT}^{40}$, que ainda acrescenta que o Percentual de Concordância e a Correlação de Pearson, usados freqüentemente para representar confiabilidade interexaminadores, apresentam muitas vezes, resultados enganosos dando origem a conclusões inadequadas.

O método de estatística KAPPA ${ }^{94}$, avalia a proporção de acordo entre dois examinadores em relação à proporção esperada ao acaso. Os valores KAPPA ${ }^{94}$ são interpretados da seguinte forma: quando o valor de $\mathrm{K}$ está na faixa entre 0 a 0,2 , a confiabilidade é considerada pobre; quando está entre 0,21 e 0,40, é regular; entre 0,41 e 0,60 considera-se moderada; 0,61 a 0,80, satisfatória e 0,81 a 1,00 excelente.

Se compararmos o método utilizado nesta pesquisa ao método KAPPA ${ }^{94}$, utilizado na grande maioria dos trabalhos, verifica-se que a concordância entre os examinadores observada nas 3 avaliações realizadas foi considerada satisfatória, apresentando uma média geral de 0.71 na confiabilidade interexaminadores.

Em nosso trabalho, foi aplicado o teste de concordância de KENDALL, por apresentar a mesma confiabilidade do teste KAPPA ${ }^{94}$, além de facilitar a interpretação dos resultados de examinadores múltiplos, uma vez que foram avaliados os resultados obtidos pelos quatro examinadores ao mesmo tempo, e não por examinadores parelhados, utilizado em quase todos os trabalhos de concordância e analisados através do teste de KAPPA ${ }^{94}$. A grande vantagem de tais testes é o fato dos mesmos considerarem e corrigirem concordâncias que venham a ocorrer meramente ao acaso, o que aumenta o grau de acurácia do teste. 
Em relação à concordância específica de determinado músculo ou grupo de músculos, constata-se, de uma maneira geral, que a concordância foi boa e não variou significantemente. Logicamente vamos encontrar algumas diferenças em relação a determinado músculo, pelos diversos motivos discutidos anteriormente, ou seja, oscilação nos sinais e sintomas do paciente, a reação do indivíduo frente à palpação, a interpretação de dor e o estado de saúde do músculo no momento da palpação. Um outro fator a ser discutido é a localização do músculo e a facilidade da identificação do mesmo.

Nossos resultados demonstraram uma melhor concordância para o músculo Esternocleidomastóideo Médio Direito, com uma média de 0.84 , sendo a pior concordância verificada para o músculo Temporal Médio Direito, com 0.56. Portanto, os músculos (em ordem decrescente) onde observou-se uma maior concordância entre os examinadores foram Esternocleidomastóideo Médio Direito (0.84), Esternocleidomastóideo Médio Esquerdo (0.80), Esternocleidomastóideo Superior Direito (0.79) e Esternocleidomastóideo Superior Esquerdo (0.77), enquanto que os músculos com uma menor concordância foram Temporal Médio Direito (0.56), Masséter Superficial Origem Direito (0.60) e Masséter Superficial Origem Esquerdo (0.63).

Diferenças significantes foram obtidas somente entre os quatro sítios mais concordantes e os três menos concordantes. Análises entre os demais sítios de palpação não demonstraram diferenças significantes.

Esses resultados diferem do trabalho de KOPP ${ }^{52}$, onde foi observada uma maior concordância em relação ao Masséter profundo (81\%), pterigóideo medial (78\%), Masséter Superficial (56\%), pterigóideo lateral (47\%) e Temporal anterior e inserção do Temporal (46\%). Mais uma vez, diferentes critérios utilizados por KOPP dificultam comparações como o presente trabalho.

Apesar de ambos os trabalhos apresentarem propostas diferentes em relação aos tipos de músculos investigados e uma discordância em termos de percentuais, houve uma certa semelhança em relação a uma maior concordância do Masséter Profundo, apresentando um índice de concordância de 0.73 a 0.76 em 
nosso trabalho, contra 0.81 no trabalho de GOULET; CLARK; FLACK ${ }^{33}$ e em relação a uma pior concordância houve uma semelhança ainda maior com o Masséter Superficial apresentando em nossos trabalhos um índice de 0.60 a 0.63 contra 56\% do trabalhos de GOULET; CLARK; FLACK ${ }^{33}$.

Uma pergunta, entretanto, permanece: quais as razões para essas diferenças em relação a determinado músculo em particular?

GOULET; CLARK; FLACK ${ }^{33}$ verificaram que os examinadores foram mais consistentes em localizar determinados locais, como por exemplo o músculo frontal, o aspecto lateral da ATM e o músculo Masséter Profundo. A explicação para isso, segundo os autores, é que determinados sítios são mais fáceis de serem localizados e estavam mais próximos de pontos de referência.

Ainda de acordo com OHRBACH; GALE ${ }^{77}$, o músculo Temporal apresentou um limiar de dor à pressão muito mais alto do que o Masséter, devido ao fato do mesmo apresentar uma maior resistência por sua localização e forma anatômica, exigindo assim mais força para se ter um estímulo adequado a fim de se ativarem os receptores periféricos responsáveis pelo relato de dor. Esses resultados estão concordantes com nossos dados, onde o músculo Temporal, de uma maneira geral, apresentou sempre uma maior concordância em relação ao Masséter.

CHUNG; UM; KIM, ${ }^{9}$ avaliando a confiabilidade intra e interexaminadores na obtenção do limiar de dor à pressão nos músculos da cabeça e pescoço, verificaram que houve excelente confiabilidade para todos os músculos, com exceção do Pterigóideo Medial e do Esternocleidomastóideo Médio, medidos nos homens. O autor concluiu que é mais fácil medir o limiar de dor à pressão em músculos como o Masséter e Temporal devido a sua acessibilidade e suporte ósseo uniforme pelo tecido ósseo subjacente. Esses resultados contrastam com os aqui obtidos, já que os músculos onde foi observada uma maior concordância entre os examinadores foram o Esternocleidomastóideo Médio Direito (0.84) e o Esternocleidomastóideo Médio Esquerdo (0.80). Deve-se ressaltar que os autores do trabalho anterior utilizaram-se do algômetro para os músculos mais concordantes. 
Já GOULET ${ }^{34}$ e colaboradores verificaram que todos os pontos avaliados apresentaram reprodutibilidade igual, tendo o Masséter Superficial, Masséter Profundo e Temporal Anterior mostrado boa a excelente reprodutibilidade (variação de 0.61 a 0.88), enquanto o Temporal médio apresentou somente reprodutibilidade moderada (com 0.44 a 0.56), resultados obtidos com as duas técnicas utilizadas (palpação manual e algômetro). Esses resultados estão concordantes com os nossos, já que obteve-se uma média de concordância de 0.60 a 0.74 , enquanto que o Temporal médio apresentou uma média de 0.56, conforme mostrado na Tabela 5.2.

Portanto, como foi até agoira relatado, percebe-se que é impossível uma reprodutibilidade total, pelas mais diversas razões, porém é de opinião geral que os músculos Masséter Profundo, Masséter Superficial e Temporal Anterior são os músculos onde se obtém a maior concordância, devido a sua maior acessibilidade e a própria anatomia, com suporte ósseo subjacente. Além disso, são geralmente os músculos mais envolvidos nas DTM e, portanto, historicamente durante os exames, tem sido sempre envolvidos nos exames de palpação. Já o Temporal Médio apresentou o menor índice de reprodutibilidade, com uma média de 0.56 de concordância, talvez porque os examinadores tiveram uma certa dificuldade em localizá-lo, como anteriormente comentado por GOULET; CLARK; FLACK ${ }^{33}$.

Em se tratando do músculo Esternocleidomastóideo, apesar de pouco citado na literatura em relação a estudos de confiabilidade, sua inclusão neste trabalho deve-se ao fato de estar quase sempre envolvido em dores referidas (pontos de gatilhos), como também em pacientes com cefaléia e disfunção cervical com concomitante DTM. Altos índices de concordância foram obtidos para esse músculo, especificamente para sua porção média. A grande razão dessa alta concordância talvez resida no fato do mesmo ser um músculo grande, mais fácil de ser palpado (de se interporem os dedos), facilmente localizado. A porção média tem sido historicamente, a região mais palpada, o que pode ter aumentado significantemente sua concordância. Já as porções superiores e inferiores são mais difíceis de localizarse, especialmente em indivíduos obesos, com acúmulo de tecido adiposo na região do pescoço. 
Um outro fator a ser considerado para todos os músculos é o lado a ser palpado (direito ou esquerdo), pois diferenças poderiam ocorrer devido à dificuldades de pressão e localização pela mão do lado não-dominante do examinador.

Como a palpação foi bilateral, obteve-se valores separados para cada lado, que foram estatisticamente semelhantes, com uma média de 0.72 no lado esquerdo e uma média de 0.69 para o lado direito.

Como pode-se notar, o lado esquerdo apresentou um resultado ligeiramente melhor em relação ao lado direito. Existem algumas razões que poderiam explicar esse fato. LIST; HELKIMO; FALK ${ }^{61}$, avaliando a confiabilidade e validade do uso do algômetro no registro da sensibilidade no músculo Masséter e Temporal anterior, encontraram resultados similares a este trabalho com relação à similaridade de concordância com os dois lados.

No trabalho de JENSEN et al. ${ }^{45}$, foi questionado aos pacientes sobre o lado dominante, perguntando-se qual seria a mão preferida para usar o martelo, uma vassoura ou uma escova de dentes. Os autores perceberam, então, que existia um limiar de dor mais alto no lado dominante do indivíduo. Esses autores encontraram índices de 0.85 para o lado direito e 0.72 para o lado esquerdo, resultados esses diferentes dos aqui relatados, com uma média de 0.72 para o lado esquerdo e 0.69 para o lado direito. Portanto, se considerarmos que os examinadores do presente trabalho eram destros, palpando com a mão direita, o lado esquerdo do paciente, seria natural que houvesse uma melhor concordância no lado esquerdo do paciente. Tais dados concordam com JENSEN ${ }^{45}$ e também com os trabalhos de GOULET et al. $^{34}$, DUINKERKE ${ }^{18}$, que, da mesma maneira, verificaram que não houve diferença significante tanto intra como interexaminadores no lado.

JENSEN ${ }^{45}$ usou algômetro na determinação do limiar de dor à pressão, e também não encontrou diferença significante entre os dois lados, concordando com FISCHER ${ }^{24}$, CHUNG; UM; KIM ${ }^{9}$, KIM et al. ${ }^{50}$, JENSEN et al. ${ }^{44}$ e CHUNG; KIM; KIM ${ }^{8}$.

Finalmente, como observado nesta discussão, fica claro que programas de calibração são efetivos no treinamento de profissionais para a realização de palpação 
muscular. Esse fato é fundamental, pois muitos tratamentos são planejados e executados com base em resultados de exame de palpação. Isto nos credencia a afirmar que, apesar de todas as variáveis envolvidas nessa análise, pode-se considerá-la um dado objetivo do exame do paciente com DTM.

No entanto, o profissional deve manter em mente que tais resultados podem ser alterados pôr processos de modulações de dor, onde uma lesão aguda dentro dos tecidos musculares pode ser seguida pôr hiper excitabilidade do SNC ${ }^{16}$, que resulta em dor provocada e espontânea generalizada, comumente observada na dor miofascial. Evidências recentes ${ }^{17}$ confirmam que o dano tecidual periférico resulta em atividade neural amplificada no local lesionado e a nível do SNC. Se similar patofisiologia é válida para as DTM miogênicas, a resposta final pode ser um quadro clínico no qual os estímulos inócuos, tais como os oriundos de mastigação normal, tornem-se dolorosos e a sensibilidade à estimulação de dor é aumentada, tornando a localização da fonte primária muito difícil.

Portanto, além do treinamento específico, o profissional envolvido no diagnóstico e tratamento das DTM tem, também, que entender os processos de transmissão de dor.

Nesse treinamento, é lícito afirmar que a palpação muscular tem um papel importante, até que novos métodos surjam e mostrem-se tão ou mais confiáveis com uma razão custo-benefício adequada. 


\section{CONCLUSÕES}




\section{CONCLUSÕES}

Em vista dos resultados obtidos no presente trabalho, pode-se concluir que:

1. Os programas de treinamento e calibração demonstraram-se eficientes na obtenção de concordância interexaminadores no exame de palpação muscular;

2. A concordância manteve-se estável por determinado tempo, não sofrendo, portanto, influência dessa variável nos três exames executados neste trabalho;

3. Não houve variações estatisticamente significantes na concordância interexaminadores em relação a determinado músculo ou grupo de músculos;

4. Não houve variações estatisticamente significantes na concordância interexaminadores em relação aos lados direito e esquerdo. 


\section{REFERÊNCIAS BIBLIOGRÁFICAS}




\section{REFERÊNCIAS BIBLIOGRÁFICAS*}

1 ATWOOD, M.J. et al. Comparison of two scales in the assessment of muscle and joint palpation tenderness in chronic temporomandibular disorders. $\mathbf{J}$. Orofac. Pain, v.7, n.4, p.403-7, Fall 1993.

2 BOHL, C.F.; KNAP, F.J. Evaluating oclusal relationship mandibular dysfunction, and temporomandibular joint pain by palpation. J. prosth. Dent., v.32, n.1, p.80-6, July 1974.

3 BRYANT, R.A. Memory for pain and affect in chronic pain patients. Pain, v.54, n.3, p.347-51, Sept. 1993.

4 CARLSON, C.R. et al. Comparison of psychologic and physiologic functioning between patients with masticatory muscle pain and matched controls. $\mathbf{J}$. Orofac. Pain, v.7, n.1, p.15-22, Winter 1993.

5 CARLSSON, G.E. et al. Intra and inter-observer variation in functional examination of the masticatory system. Swet dent. J., v.4, p.187-94, 1980.

6 CECERE, F; RUF, S.; PANCHERZ, H. Is quantitative electromyography reliable?. J. Orofac. Pain, v.10, n.1, p.38-47, 1996.

7 CHAPMAN, C.R. et al. Pain measurement: an overview. Pain, v.22, p.1-31, 1985.

\footnotetext{
Normas recomendadas para utilização no âmbito da Universidade de São Paulo, com base no documento "Referências Bibliográficas: exemplos", emanado do Conselho Superior do Sistema Integrado de Bibliotecas da USP, em reunião de 20 de setembro de 1990.
} 
8 CHUNG, S.C.; KIM, J.H.; KIM, H.S. Reliability and validity of the pressure pain thresholds (PPT) in the TMJ capsules by electronic algometer. J. craniomandibular Practice, v.11, n.3, p.171-6, July 1993.

9 CHUNG, S-C.; UM, B-G.; KIM, H-S. Evaluation of pressure pain threshold in head and neck muscles by eletronic algometer. Intrarater and interrater reliability. J. craniomandibular Practice, v.10, n.1, p.28-34, 1992.

10 CLARK, G.T.; DELCANHO, R.E.; GOULET, J.P. The utility and validity of current diagnostic procedures for defining temporomandibular disorder patients. Adv. dent. Res., v.7, n.2, p.77-112, Aug. 1993.

11 CONTI, P.C.R. et al. A comparative study between manual inspection and a computer based analysis. J. Orofac. Pain, v.13, n.2, p.141, 1999.

12 COSTEN, J.B. A syndrome of ear and sinus symptoms dependent upon disturbed functions of TMJ. Ann. Otol. v.43, n.1, p.1-15, Mar. 1934.

13 DAHLTRÖN, L. et al. Evaluation of a training program intended to calibrate examiners of temporomandibular disorders. Acta Odont. Scand., v.52, p.250-4, 1994.

14 DAVENPORT, J.C. Pressure-pain thresholds in the oral cavity in man. Arch. oral Biol., v.14, p.1267-74, 1969.

15 DOUGLAS, C.W. Evaluating diagnostic tests. Adv. dent. Res., v.7, n.2, p.66-9, Aug. 1993.

16 DUBNER, R. Neuronal plasticity and pain following peripheral tissue inflammation on nerve injury. In: DUBNER, R; GEBHART, B. eds. WORLD CONGRESS ON PAIN, 5., Proceedings. New York, Elsevier, 1991. 
17 DUBNER, R. Spinal cord neuroplasticity. In: VECCHIET, L.; LINDBLOOM, V. Mechanisms of persistent pain following tissue damage and nerve injury. In: INTERNATIONAL CONGRESS ON NEW TRENDS IN REFERRED PAIN AND HYPERALGESIA. Proceedings., Italy, s.ed., 1993.

18 DUINKERKE, A.S.H. et al. Reproducibility of a palpation test for the stomatognathic system. Community Dent. oral Epidem. V.14, P.80-5, 1986.

19 DWORKIN, S.F.; LE RESCHE, L. Research diagnostic criteria for temporomandibular disorders: review, criteria, examinations and specifications, critique. J. craniomandibular dis. fac. oral pain, v.6, n.4, p.301-55, 1992.

20 DWORKIN, S.F.; LE RESCHE, L.; DE ROUEN, T. Reliability of clinical measurement in temporomandibular disorders. Clin. J. Pain., v.4, n.2, p.8999, 1988.

21 DWORKIN, S.F. et al. Assessing clinical signs of temporomandibular disorders: Reliability of clinical examiners. J. prosth. Dent., v.63, n.5, p.574-9, May 1990.

22 ELLERMEIER, W.; WESTPHAL, W. Gender differences in pain ratings and pupil reactions to painful pressure stimuli. Pain, v.61, p.435-9, 1995.

23 ERIKSSON, L.; WESTESSON, P.; SJÖBERG, H. Observer performance in describing temporomandibular joint sounds. J. craniomandibular Practive, v.5, n.1, p.32-5, Jan. 1987.

24 FISCHER, A.A. Pressure threshold measurement for diagnosis of myofascial pain and evaluation of treatment results. Clin. J. Pain, v.2, p.207-14, 1987.

25 FLEISS, J.L.; CHILTON, N.W. The measurement of interexaminer agreement in periodontal desease. J. Periodont. Res., v.18, p.601-6, 1983. 
26 FRICTON, J.R. Measuring outcome of treatment for temporomandibular disorders. In: FRICTON, J.R.; DUBNER, R. Orofacial pain and temporomandibular disorders. New York, Raven Press, 1995.

27 FRICTON, J.R.; SCHIFFMAN, E.L. Reliability of a craniomandibular index. J. dent. Res., v.65, n.11, p.1359-64, Nov. 1986.

28 FRICTON, J.R.; SCHIFFMAN, E.L. The craniomandibular index: validity. J. prosth. Dent., v.58, n.2, p.222-8, Aug. 1987.

29 FRIEDMAN, M.H.; WEISBERG, J. Pitfalls of muscle palpation in TMJ diagnosis. J. prosth. Dent., v.48, n.3, p.331, 1982.

30 GALLAGHER, R.W.; DAL SANTO, F.B.; RUGH, J.D. Design and construction of a pressure algometer. J. craniomandibular dis. fac. oral pain, v.3, p.15962, 1989.

31 GOULET, J.P; CLARK, G.T. Clinical TMJ examination methods. J. Calif. dent. Ass., v.18, n.3, p.25-33, Mar. 1990.

32 GOULET, J.P; CLARK, G.T.; FLACK, V.F. Reversal of symptons reported by subjects during repeated TMJ exams. J. dent. Res., v.70, p.371, 1991./Abstract 849/

33 GOULET, J.P; CLARK, G.T.; FLACK, V.F. Reproducibility of examiner performance for muscle and joint palpation in the temporomandibular system following training and calibration. Community Dent. oral Epidem., v.21, p.72-7, 1993.

34 GOULET, J.P et al. The reproducibility of muscle and joint tenderness detection method and maximum mandibular movement measurement for the temporomandibular system. J. Orofac. Pain, v.12, p.17-26, 1998. 
35 GRACELY, R.H.; REID, K.I. Orofacial pain measurement. In: FRICTON, J.R.; DUBNER, R. Orofacial pain and temporomandibular disorders. New York, Raven Press, 1995.

36 GRAY, R.J.M.; DAVIES, S.J.; QUAYLE, A.A. Temporomandibular disorders. A clinical approach to temporomandibular disorders. 3. Examination of the articulatory system: the muscles. Brit. dent. J., v.177, n.1, p.25-8, July 1994.

37 GRIFFITH, R.H. Report of the President's Conference of the Examination, Diagnosis and Management of Temporomandibular Disorders. J. Amer. dent. Ass., v.106, p.75-8, Jan. 1983.

38 GROSS, A.; GALE, E.H. A prevalence study of the clinical signs associated with mandibular dysfunction. J. Amer. dent. Ass., v.107, n.6, p.932-6, Dec. 1983.

39 HARDY, J.D.; WOLFF, H.G.; GOODELLI, H. Pain sensations and reactions. Baltimore, 1952.

40 HUNT, R.J. Percent agreement, Pearson's Correlation and KAPPA measures of inter-examiner reliability. J. dent. Res., v.65, n.2 p.128-30, 1986.

41 ISSELÉE, $H$. et al. Short-term reproducibility of pressure pain threshould in masseter and temporalis muscles of symptom-free subjects Europ. J. Oral, v.105, n.6, p.583-7, 1997.

42 ISSELÉE, H. et al. Short-term reproducibility of pressure pain threshould in masticatory muscles measured with a new algometer. J. Orofac. Pain, v.12, p.203-9, 1998.

43 JAEGER, B.; REEVES, J.L. Quantification of changes in myofascial trigger points sensitivity with the pressure algometer following passive stretch. Pain, v.27, p.203-10, 1986.

44 JENSEN, R. et al. Pressure-pain threshold in human temporal region. Evaluation of a new pressure algometer. Pain, v.25, p.313-23, 1986. 
45 JENSEN, R. et al. Cephalic muscle tenderness and pressure pain threshold in a general population. Pain, v.48, p.197-203, 1992.

46 JIMENEZ, A.C.; LANE, M.E. Serial determinations of pressure threshold tolerance in chronic pain patients. Arch. Phys. Med. Rehabil., v.66, p.545-6, 1985.

47 JOHNSTONE, D.R.; TEMPLETON, M. The feasibility of palpating the lateral pterygoid muscle. J. prosth. Dent., v.44, n.3, p.318-23, 1980.

48 JOSEPH, L. et al. Inter-examiner reliability in caries trials. J. dent. Res., v.58, n.2, p.604-9, Feb. 1979.

49 KEELE, K.D. Pain - sensitivity testes. Lancet, v.27, p.636-9, 1954.

$50 \mathrm{KIM}, \mathrm{H}-\mathrm{S}$. et al. Pain-pressure threshold in the head and neck region of episodic tension-type headache patients. J. Orofac. Pain, v.9, p.357-64, 1995.

51 KLEINKNECHT, R.A. et al. Correspondence between subjective report of temporomandibular disorders symptoms and clinical findings. J. Amer. dent. Ass., v.113, p.257-261, Aug. 1986.

52 KOPP, S. Constancy of clinical signs in patients with mandibular dysfunction. Community Dent. oral Epidem., v.5, p.94-8, 1977.

53 KOPP, S.; WENNEBERG, B. Intra and interobserver variability in the assessment of signs of disorder in the stomatognathic system. Swed. dent. J., v.7, p.239-46, 1983.

54 KROGSTAD, B.S. et al. Sex differences in signs and symptoms from masticatory and other muscles in 19-years-old individuals. J. Oral Rehab., v.19, p.43540, 1992.

55 LANGEMARK, M. et al. Pressure pain thresholds and thermal nociceptive thresholds in chronic tension-type headache. Pain, v.38, p.203-10, 1989. 
56 LASKIN, D.M. Etiology of the pain dysfunction syndrome. J. Amer. dent. Ass., v.79, n.6, p.147-53, July 1969.

57 LE RESCHE, L.; BURGESS, J.; DWORKIN, S.F. Reability of visual analog and verbal descriptor scales for "objetive" measurement of temporomandibular disorder pain. J. dent. Res., v.67, n.1, p.33-6. Jan. 1988.

58 LE RESCHE, L. et al. Effect of temporomandibular disorder pain duration on facial expressions and verbal report of pain. Pain, v.51, p.289-95, 1992.

59 LIBMAN, E. J. Amer. Med. Ass., v.102, p.335, 1934. apud KEELE, K.D. Pain sensitivity tests. Lancet, v.27, p.636-9, 1954.

60 LIST, T.; HELKIMO, M. Method for measuring muscle pain with the aid of algometer. Swed. dent. J., v.11, p.294, 1987. /abstract 69/

61 LIST, T.; HELKIMO, M.; FALK, G. Reliability and validity of a pressure threshold meter in recording tenderness in the masseter muscle and the anterior temporalis muscle. J. craniomandibular Practice, v.11, n.3, p.223-9, July 1989.

62 LOBBEZOO-SCHOLTE, A.M. et al. Interexaminer RELIABILITY of six orthopaedic tests in diagnostic subgroups of craniomandibular disorders. J. oral Rehab., v.21, p.273-85, 1994.

63 LOBBEZOO-SCHOLTE, A.M. et al. Diagnostic subgroup of craniomandibular disorders. Part I: self-report data and clinical findings. J. Orofac. Pain, v.9, n.1, p.24-36, 1995.

64 MCMILLAN, A.S.; LAWSON, E.T. Effect of tooth clenching and jaw opening in pain-pressure thresholds in the human jaw muscles. J. Orofac. Pain, v.8, p.250-7, 1994.

65 MCNEILL, C. Temporomandibular disorders. Guidelines for classification, assessment and management. 2.ed. Chicago, Quintessence, 1993. 
66 MCNEILL, C. et al. Craniomandibular (TMJ) disorders. The state of the art. J. prosth. Dent.., v.44, n.4, p.434-7, Oct. 1980.

67 MCNEILL, C. et al. Temporomandibular disorders, diagnosis, management, education and research. J. Amer. dent. Ass., v.120, p.253-63, Mar. 1990.

68 MERSKEY, H. Pain terms: a list with definitions and notes on usage. Recommended by the IASP Subcommittee on Toxonomy. Pain, v.6, p.249$52,1979$.

69 MIKHAIL, M.; ROSEN, H. History and etiology of myofascial pain-dysfunction syndrome. J. prosth. Dent.., v.44, n.4, p.438-44, Oct. 1980.

70 MILNER, D. et al. TMJ Sounds: characteristics and examiner reliability. J. dent. Res., v.70, p.371, 1991./Abstract 848/

$71 \mathrm{MOHL}$, N.D. Reliability and validity of diagnostic modalities for temporomandibular disorders. Adv. dent. Res., v.7, n.2, p.113-9, Aug. 1993.

$72 \mathrm{MOHL}$, N.D. et al. Devices for the diagnosis and treatment of temporomandibular disorders. Part I: Introduction, scientific, evidence and jaw tracking. J. prosth. Dent., v.63, n.2, p.198-201, 1990.

73 MOODY, P.M. et al. Stress-pain relationship in MPD syndrome patients and nonMPD syndrome patients. J. prosth. Dent., v.45, n.1, p.84-9, 1981.

74 NEWHAUSER, D.; YIN, X.P. Decidiny whether a new test measure is useful. Medical Care, v.29, p.685-9, 1991.

75 OAKLEY, M.E. et al. Dentists ability to detect psychological problems in patients with temporomandibulars disorders and chronic pain. J. Amer. dent. Ass., v.118, p.727-30, 1989.

76 OLDHAM, P.D. Observer error in medicine. Proc. Roy. Soc. Med, v.61, p.44754, May 1968. 
77 OHRBACH, R; GALE, E.N. Pressure pain threshold in normal muscles: reliability, measurement effects and topographic differences. Pain, v.37, p.257-63, 1989.

78 OHRBACH, R; GALE, E.N. Pressure pain thresholds, clinical assessment and differential diagnosis: RELIABILITY and validity in patients with myogenic pain. Pain, v.39, p.157-69, 1989.

79 OKESON, J.P. Dor orofacial. Guia de avaliação, diagnóstico e tratamento. Academia Americana de Dor Orofacial. São Paulo, Quintessence, 1988.

80 OKESON, J.P. Dores bucofaciais de Bell. 5.ed. São Paulo, Quintessence, 1998.

81 PAESANI, D.A. et al. Evaluation of the reproducibility of rest activity of the anterior temporal and masseter muscles in asymptomatic and symptomatic temporomandibular subjects. J. Orofac. Pain, v.8, p.402-6, 1994.

82 PRENTISS, H.A. A preliminary report upon the temporomandibular articulation in the human type. Dent. Cosmos, v.60, n.6, p.505-12, June 1918.

83 REEVES, J.L.; JAEGER, B.; GRAFF-RADFORD, S.B. Reliability of the pressure algometer as a measure of myofascial trigger point sensitivity. Pain, v.24, p.313-21, 1986.

84 REID, K.I.; GRACELY, R.H.; DUBNER, R.A. The influence of time, facial side and location of pain-pressure thresholds in chronic myogenous temporomandibular disorder. J. Orofac. Pain, v.8, n.3, p.258-65, 1994.

85 ROBERTS, C.A. et al. Comparison of arthrographic findings of the temporomandibular joint with palpation of the muscles of mastication. Oral Surg., v.64, p.275-7, 1987. 
86 SCHIFFMAN, E.L. et al. A pressure algometer for myofascial pain syndrome: reliability and validity. In: DUBNER, R.; GEBHART, G.F.; BONDS, M.R. WORLD CONGRESS ON PAIN, 5., Proceedings. Amsterdam, Elsevier, 1988. p.407-13.

87 SCHULTZ, L. A curative treatment fos subluxation of the temporomandibular joint. J. Amer. dent. Ass., v.24, n.12, p.1947-50, Dec. 1937.

88 SCHWARTZ, L. Pain associated with the temporomandibular joint. J. Amer. dent. Ass., v.51, n.10, p.394-401, Oct. 1955.

89 SICHER, H. Temporomandibular articulation in mandibular overclosure. J. Amer. dent. Ass., v.36, n.2, p.131-9, Feb. 1948.

90 SMITH, J.P. Observer variation in the clinical diagnosis of mandibular pain dysfunction syndrome. Community Dent. oral Epidem., v.5, n.2, p.91-3, 1977.

91 SOLBERG, W.K. Temporomandibular disorders physical tests in diagnosis. Brit. dent. J., v.160, p.273-7, 1986.

92 STOCKSTILL, J.W.; GROSS, A.J.; MCCALL, W.D. Interrater reliability in masticatory muscle palpation. J. craniomandibular dis. fac. oral pain, v.3, p.143-6, 1989.

93 STOREY, A.T.; RUGH, J.D. How to carry out temporomandibular disorders research in a clinical practice. In: FRICTON, J.R.; DUBNER, R.B. Orofacial pain and temporomandibular disorders. New York, Raven Press, 1995.

94 SUVINEN, T.I.; READE, P.C. Temporomandibular disorders: a critical review of the nature of pain and its assessment. J. Orofac. Pain, v.9, p.317-39, 1995. 
95 SVENSSON, P. et al. Effect of chronic and experimental jaw muscle pain on pain-pressure thresholds and stimulus - response curves. J. Orofac. Pain, v.9, p.347-56, 1995.

96 THOMAS, C.A.; OKESON, J.P. Evaluation of lateral pterygoid muscle symptoms using a common palpation technique and a method of functional manipulation. J. craniomandibular Practice, v.5, p.125-9, Apr. 1987.

97 TRUELOVE, E. et al. Reliability of TMJ sounds in patients and controls. J. dent. Res., v.66, p.336, 1987./Abstract 1839/

98 TUNKS, E. et al. Tender points in fibromyalgia. Pain, v.34, p.11-9, 1988.

99 VALACHOVIC, R.W. et al. Examiner reliability in dental radiography. J. dent. Res., v.65, n.3, p.432-6, Mar. 1986.

100 WAHLUND, K.; LIST, T.; DWORKIN, S.F. Temporomandibular disorders in children and adolescents: reliability of a questionnaire, clinical examination and diagnosis. J. Orofac. Pain, v.12, n.1, p.42-51, 1998.

101 WÄNMAN, A. The relationship between muscle tenderness and craniomandibular disorders: A study of 35 years-old. From the general population. J. Orofac. Pain, v.9, p.235-43, 1995.

102 WÄNMAN, A.; AGERBERG, G. Mandibular dysfunction in adolescents II. Prevalence of signs. Acta Odont. Scand., v.44, p.55-62, 1986.

103 WEINBERG, L.A. The etiology, diagnosis and treatment of TMJ dysfunction-pain syndrome. Part II: Differential diagnosis. J. prosth. Dent., v.43, n.1, p.58-70, Jan. 1980.

104 WHITNEY, C.W.; KORFF, M.V. Regression to the mean in treated versus untreated chronic pain. Pain, v.50, p.281-5, 1992. 
105 WIDMER, et al. Evaluation of diagnostic tests for TMD. CDA Journal, v.18, n.3, p.53-60, Mar. 1990.

106 WIJER, A. et al. Reliability of clinical findings in temporomandibular disorders. J. Orofac. Pain, v.9, p.181-91, 1995. 
ABSTRACT 


\section{ABSTRACT}

This study aimed to evaluate the interexaminer agreement when performing muscle palpation, after a trainning and calibration program. Reliability related to the time of examination and the side palpated were also addressed.

Sample was composed of 32 individuals, matched for sex and divided into two groups: symptomatic (16 patients presenting with myogenic TMD) and asymptomatic (16 patients with no TMD symptoms).

Palpation procedures were perfomed in three different times by four examiners, in masticatory (masseter and temporalis) and cervical (sternocleidomastoid - SCM) muscles.

The prescuse and severity of muscle tenderness was judge by an ordinal scale (from "0" to "3"). Kendall's concordance test measured agreement between examiners.

SCM has shown the highest concordance $(0.84)$ while the worst result was found for the origin of masseter $(0.56)$.

Levels of concordance for all muscles were considered fair and excellent, regardless the side or the time of examination. Authors concluded that a calibration program is able to standardize muscle palpation, which makes such procedure an important step in TMD evaluation. 